SUPPORTING INTEGRATION?

INTERNATIONAL PRACTICES ON CIVICS

AND LANGUAGE REQUIREMENTS

LINKED TO NATURALISATION:

POLICY IMPLICATIONS FOR IRELAND

Sarah Groarke, Michal Polakowski,

Emma Quinn, Frances McGinnity

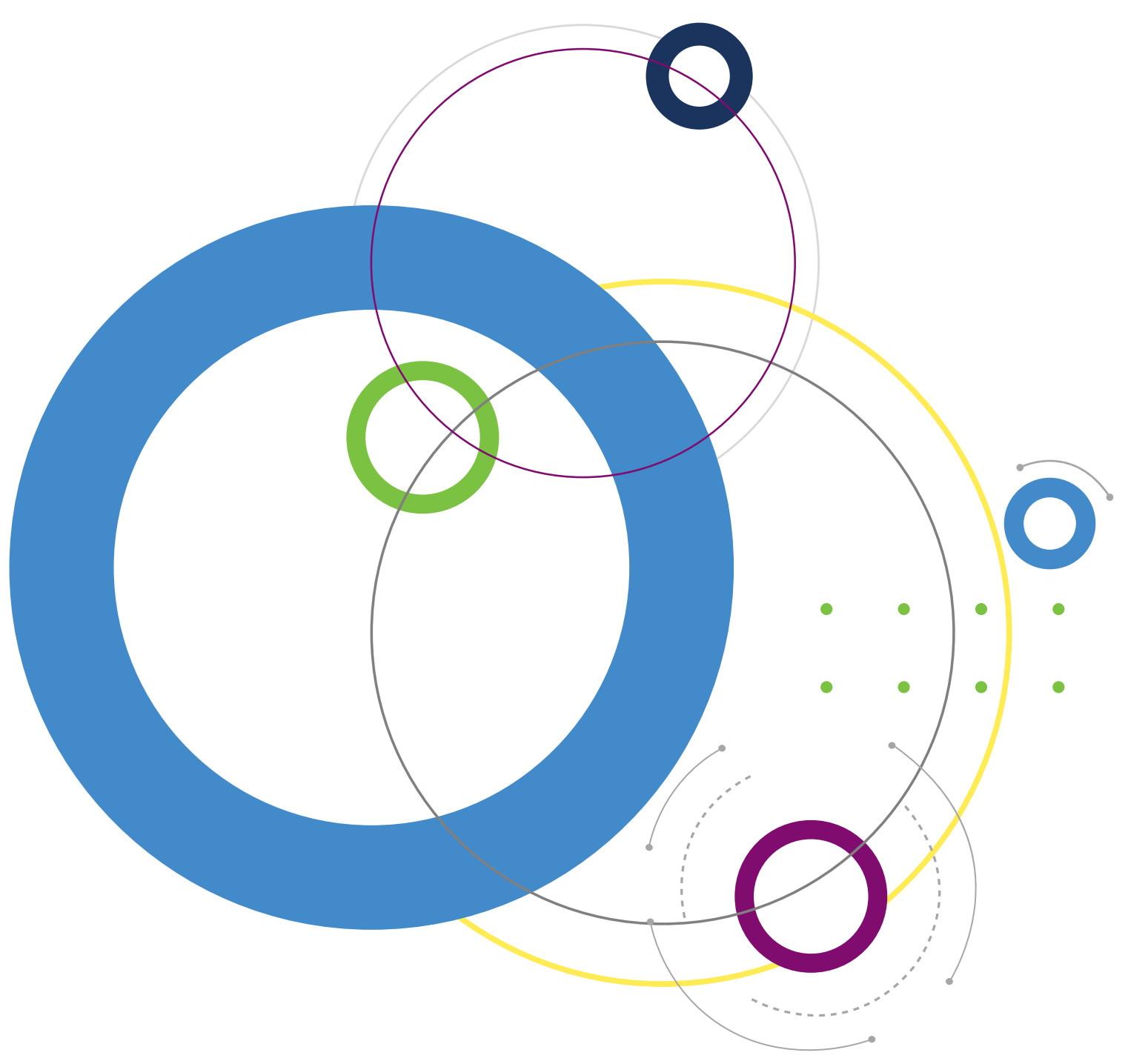




\title{
Supporting integration? International practices on civics and language requirements linked to naturalisation: policy implications for Ireland
}

\author{
Sarah Groarke \\ Michal Polakowski \\ Emma Quinn \\ Frances McGinnity
}

September 2020

Economic and Social Research Institute;

Department of Justice and Equality

Available to download from www.esri.ie

(C) 2020 Economic and Social Research Institute

Whitaker Square, Sir John Rogerson's Quay, Dublin 2

https://doi.org/10.26504/bkmnext398

ISBN: 978-0-7070-0535-5

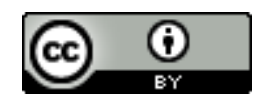

This Open Access work is licensed under a Creative Commons Attribution 4.0 International License (https://creativecommons.org/licenses/by/4.0/), which permits unrestricted use, distribution, and reproduction in any medium, provided the original work is properly credited. 



\section{ABOUT THE ESRI}

The mission of the Economic and Social Research Institute is to advance evidencebased policymaking that supports economic sustainability and social progress in Ireland. ESRI researchers apply the highest standards of academic excellence to challenges facing policymakers, focusing on 12 areas of critical importance to $21^{\text {st }}$ Century Ireland.

The Institute was founded in 1960 by a group of senior civil servants led by Dr T.K. Whitaker, who identified the need for independent and in-depth research analysis to provide a robust evidence base for policymaking in Ireland.

Since then, the Institute has remained committed to independent research and its work is free of any expressed ideology or political position. The Institute publishes all research reaching the appropriate academic standard, irrespective of its findings or who funds the research.

The quality of its research output is guaranteed by a rigorous peer review process. ESRI researchers are experts in their fields and are committed to producing work that meets the highest academic standards and practices.

The work of the Institute is disseminated widely in books, journal articles and reports. ESRI publications are available to download, free of charge, from its website. Additionally, ESRI staff communicate research findings at regular conferences and seminars.

The ESRI is a company limited by guarantee, answerable to its members and governed by a Council, comprising 14 members who represent a cross-section of ESRI members from academia, civil services, state agencies, businesses and civil society. The Institute receives an annual grant-in-aid from the Department of Public Expenditure and Reform to support the scientific and public interest elements of the Institute's activities; the grant accounted for an average of 30 per cent of the Institute's income over the lifetime of the last Research Strategy. The remaining funding comes from research programmes supported by government departments and agencies, public bodies and competitive research programmes.

Further information is available at www.esri.ie 


\section{THE AUTHORS}

Sarah Groarke and Michal Polakowski are Policy Officers at the Irish National Contact Point of the European Migration Network (EMN Ireland), within the Economic and Social Research Institute (ESRI). Emma Quinn is the Head of EMN Ireland. Frances McGinnity is an Associate Research Professor at the ESRI and Adjunct Professor at TCD.

\section{ACKNOWLEDGEMENTS}

This report was completed as part of a programme of research on Equality and Integration funded by the Department of Justice and Equality (DJE). We would like to thank our colleagues within the European Migration Network (EMN) national contact points of Belgium, Finland, Portugal and the UK, who provided valuable assistance in making contact with national officials responsible for policy on citizenship. We are very grateful to the following national officials who provided input to, and reviewed drafts of, the case studies: representatives of the Nationality Division of the Belgian Federal Public Service for Justice's Directorate General on Legislation, Fundamental Rights and Freedoms; the Nationality Unit of the Legal and Support Services within the Finnish Immigration Service; and the Passport and Nationality Policy Unit of the Borders, Immigration, Citizenship System, Policy and International Division of the UK Home Office. We would like to thank the Centre of Linguistics of the University of Lisbon (CLUL). We are also very grateful to Patrícia Jerónimo, Associate Professor at the Faculty of Law of the University of Minho, Portugal, for providing input and comments on the case study on Portugal. We would like to thank the members of the steering group for the research programme: Úna Ní Dhubhghaill (DJE), Alice Wainwright (DJE) and Philip O'Connell (University College Dublin). We thank our ESRI colleagues and the external reviewer who reviewed the draft report. We would also like to thank Anna de Courcy, who copy-edited the report, and Sarah Burns, who managed its publication.

Disclaimer: This report has been peer reviewed prior to publication. The authors are solely responsible for the content and the views expressed. 


\section{FOREWORD}

Citizenship, acquired through naturalisation, is widely acknowledged as a key measure of integration and therefore an important element of integration policy. As this report Supporting integration? International practices on civics and language requirements linked to naturalisation: policy implications for Ireland puts it: citizenship may be viewed as the highest level of 'membership' available to migrants in their host country. Over 153,000 non-Irish nationals acquired Irish citizenship through naturalisation between 2005 and 2019. With almost 12 per cent of people living here having a nationality other than Irish, and a growing second and third-generation of Irish-born children of migrants, the question of citizenship and the benefits it brings is coming ever more sharply into focus. Naturalised migrants may participate fully in the democratic process and are entitled to equal access to the institutions, employment, goods and services of the State. Acknowledging the importance of citizenship, its role and meaning in the integration journey, in turn stimulates discussion of the benefits and limitations of language and civic requirements for naturalisation.

This study has been produced under the ESRI's Equality and Integration Research Programme. This Programme is funded by the Department of Justice and Equality in line with the objective of the Migrant Integration Strategy to support research that provides independent evidence for policy on equality and integration matters.

The Migrant Integration Strategy is underpinned by the vision that migrants are facilitated to play a full role in Irish society, that integration is a core principle of Irish life and that Irish society and institutions work together to promote social inclusion.

Under Action 12 of the Strategy, the Immigration and Naturalisation Service of the Department of Justice and Equality committed to examine the introduction of civics and language tests for those seeking citizenship. This study will inform this work by giving a clear picture of international practices in this area and drawing attention to issues that Ireland would need to consider in the design of any new policy on citizenship requirements.

This is a complex area, as evidenced in the study, and the design and implementation of policy in respect of civic and language requirements for citizenship can be challenging. It prompts important questions about states' understandings of citizenship, the rights and responsibilities it confers and the expectations states may have of their citizens. As such, the study represents a 
valuable contribution to informed policy debate on the issue and will be of value to all with an interest in this area.

This is timely research, that will guide our policy formulation at this critical moment in Irish society in supporting the journey to citizenship that many of our migrants will take.

Department of Justice and Equality

September 2020 


\section{TABLE OF CONTENTS}

EXECUTIVE SUMMARY

VII

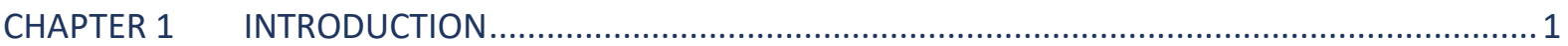

$1.1 \quad$ Civics and language tests for naturalisation........................................................... 1

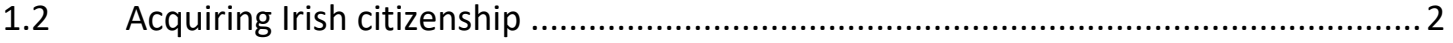

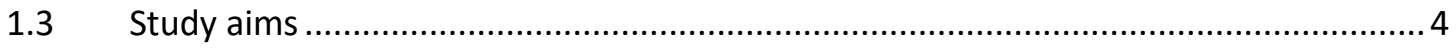

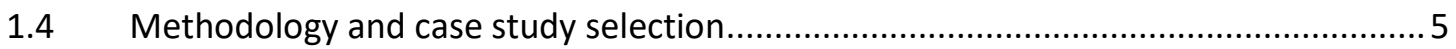

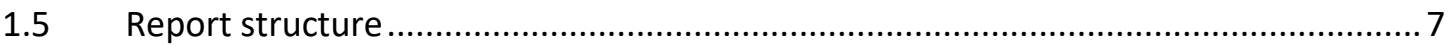

CHAPTER 2 APPROACHES TO CITIZENSHIP, NATURALISATION REQUIREMENTS AND MIGRANT

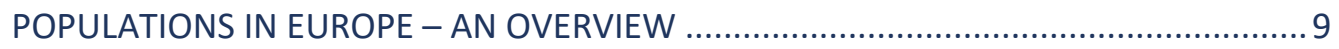

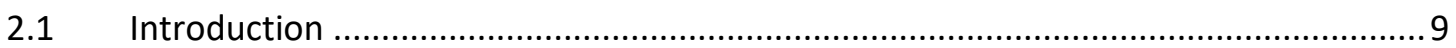

2.2 Naturalisation requirements and the 'civic turn' .................................................... 9

2.3 Dimensions and meanings of citizenship from a migration perspective ....................11

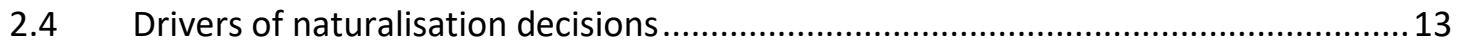

2.5 A profile of migrant populations in EU countries: Ireland in comparative perspective

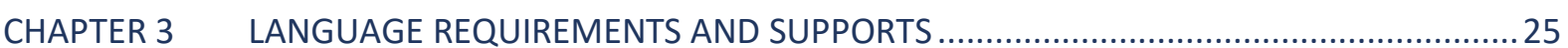

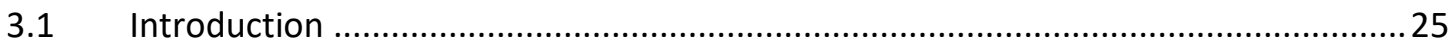

3.2 Common European Framework of Reference for Languages ......................................25

3.3 Overview of language requirements for citizenship applicants in EU Member

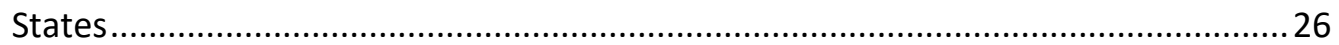

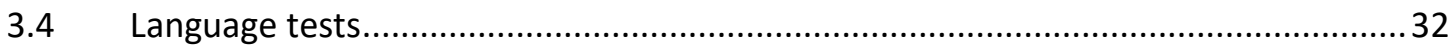

3.5 Host-country school or university certificates and other documentary evidence ......37

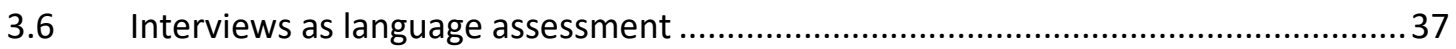

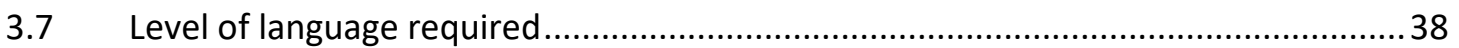

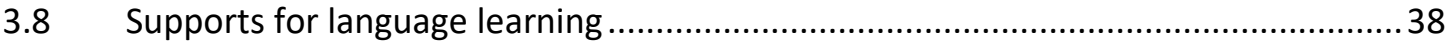

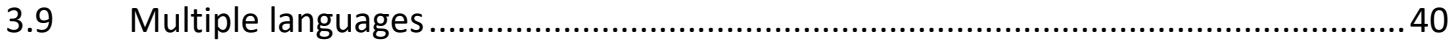

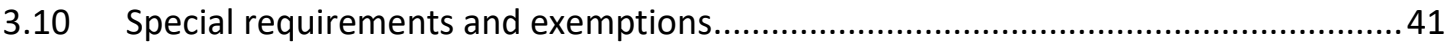

3.11 Evaluations of citizenship language requirements ...................................................42

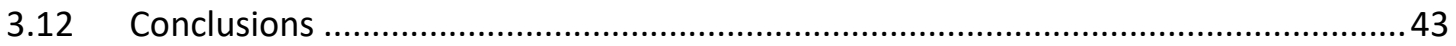


CHAPTER $4 \quad$ CIVIC KNOWLEDGE/INTEGRATION REQUIREMENTS AND SUPPORTS..........................45

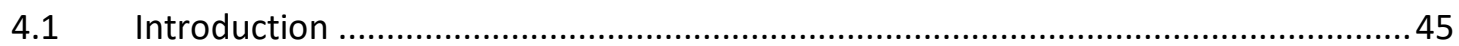

4.2 Overview of civic knowledge/integration requirements in EU Member States

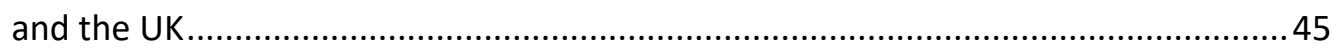

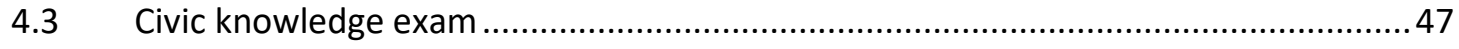

4.4 Interviews as civic knowledge assessment …..........................................................50

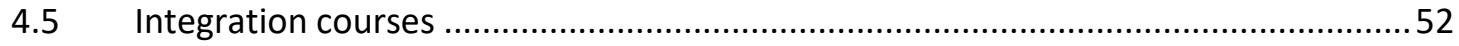

4.6 Exemptions and adapted requirements.............................................................

4.7 Evaluations of civic knowledge / integration requirements .....................................55

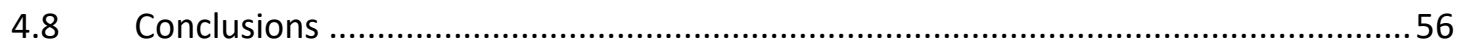

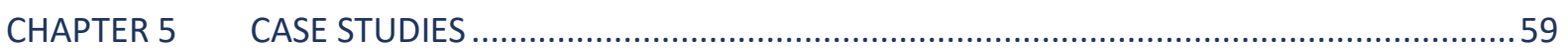

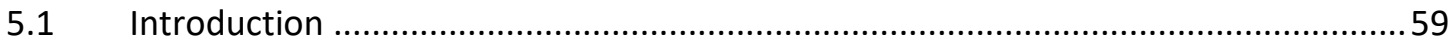

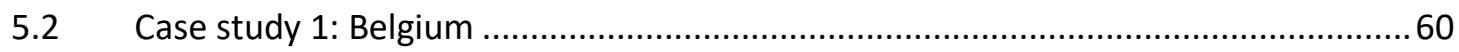

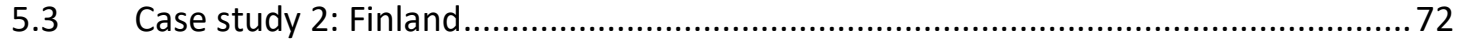

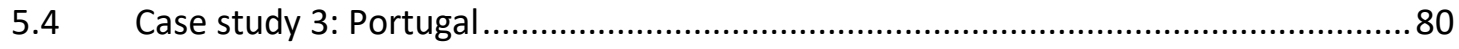

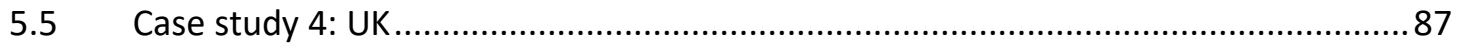

5.6 Case study 5: English language speaking countries outside the EU............................97

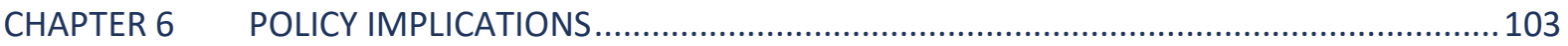

6.1 Introduction of requirements in Ireland would represent a significant new

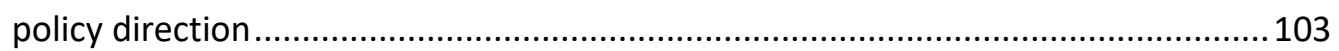

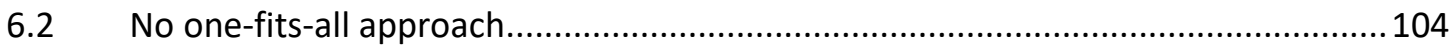

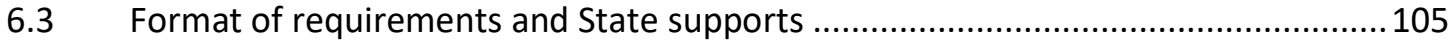

6.4 Requirements and supports tailored to individual needs......................................111

6.5 Tendency towards introduction of stricter requirements once in place .................112

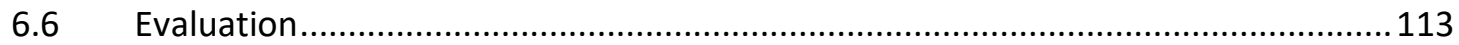




\section{LIST OF TABLES}

Table 3.1 Common European framework of reference for languages (CEFR): Global scale: common reference levels, abridged

Table 3.2 Overview of language requirements and related supports in EU Member States plus the UK.

Table 4.1 Summary of civic knowledge/integration requirements in EU Member States and the UK 46

Table 5.1 Summary of requirements in selected case studies 59

\section{LIST OF FIGURES}

Figure 2.1 The distribution of citizenship acquisition in EU Member States by origin, 2018...... 16

Figure 2.2 Share of non-citizens in the EU Member States' populations, 2018 ......................... 17

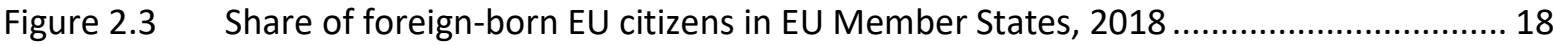

Figure 2.4 The distribution of all valid residence permits for non-EU nationals in EU Member States by reason, 2018............................................................................. 20

Figure 2.5 The employment rates of the native population, non-EU and EU migrants, Q3 2019. 



\section{EXECUTIVE SUMMARY}

Citizenship acquired by naturalisation may be viewed as the highest level of 'membership' potentially available to migrants in their host State. Naturalised citizens have rights and responsibilities identical to citizens by birth. The acquisition of citizenship is itself viewed as a key measure to facilitate the integration of migrants in the host society. Several European states have introduced language and knowledge of society (civics) requirements related to naturalisation, though there are no requirements in Ireland. Action 12 of the Migrant Integration Strategy 2017-2020 states that the introduction of both civics and language tests for those seeking citizenship will be examined. This research study, carried out on behalf of the Department of Justice and Equality, aims to contribute to such an assessment by investigating language and civic requirements for naturalisation elsewhere in Europe. The report provides an overview of requirements adopted for naturalisation in EU Member States and the UK, and a 'deep dive' into practices in selected case study countries particularly relevant for Ireland.

The introduction of language and civic requirements for naturalisation brings into sharp focus the role and meaning of citizenship, given that citizenship confers the unconditional right to enter and remain in the host country and enjoy a full spectrum of rights and duties. Devising such tests can be challenging, both in terms of the type of knowledge required and what this implies about a State's understanding of citizenship, as well as how much applicants should know. If applicants are expected to demonstrate knowledge that far exceeds that of the native-born population, this begs the question of 'super citizen' requirements (Badenhoop, 2017).

The move towards language and civics requirements has been coined the 'civic turn' in literature on the topic. The 'civic turn' has been identified as a policy response to a perceived 'crisis of integration' in some Member States. Ireland is unusual in several respects. Many migrants are labour migrants from the EU; for non-EU migrants Ireland has a selective immigration policy which promotes highlyskilled migrants, and a significant proportion of non-EU migrants come to Ireland to work or to study. Incentives to naturalise differ for migrants, particularly EU and non-EU nationals: typically, non-EU nationals are more likely to naturalise in European countries than EU nationals.

\section{LANGUAGE REQUIREMENTS}

Twenty-four EU Member States plus the UK have a language requirement in law for citizenship applicants and three do not: Ireland, Cyprus, and Sweden. Almost 
all Member States seek competence in the four components of listening, speaking, reading and writing.

The level of language skill required from citizenship applicants varies. Eight Member States set the standard at 'basic or elementary user'; ten Member States plus the UK seek evidence of competence at 'independent user' level (lower intermediate); and two Member States set a slightly higher language standard. In four countries no language level is specified. There is also considerable diversity in how the language requirement is applied in practice, from a simple declaration made by the applicant, to structured tests specifically designed for citizenship applicants or certified proof of an equivalent level of competence. Language requirements in Europe have become increasingly strict with more countries introducing or formalising a requirement in recent years.

Language tests for migrants are complex to design and implement, partly due to the significant variation among candidates in terms of demographics, literacy, education and skills background. Evaluations of the decision to introduce language requirements attached to naturalisation and their potential impact were not found in our review of the literature and practice in the EU.

\section{‘KNOWLEDGE OF SOCIETY’ REQUIREMENTS}

Eighteen EU Member States and the UK currently require applicants to demonstrate civic knowledge or 'integration' as part of the naturalisation process. There is a diverse range of approaches to such requirements, with practice varying from written exams, attendance at an interview, or completion of an integration course. All of these are carried out in the host country language.

Knowledge required may include the country's Constitution, democratic and political system, history, geography, culture and customs, current affairs and events and access to public goods and services. In more limited cases, exams also include questions on social morals and values. Little information is available on how the civics content and material have been devised in the countries examined, and in some countries, the content, and its purpose, is contested.

There is generally no cost for applicants, however in some countries applicants must pay for preparation materials for exams. The use of exemptions and adapted assessments varies significantly, but very few countries provide adapted assessment methods for people with disabilities or people with low levels of literacy or formal education. Countries with a civics requirements report that no evaluations have been conducted, so little is known about the impact of civic requirements for naturalisation on integration. 


\section{CASE STUDIES}

The report presents four European case studies - Belgium, Finland, Portugal and the United Kingdom. Case studies were selected on the basis of commonalities with Ireland in terms of population size, official languages, migration history and profile of the migrant population. We also sought diversity among the case studies in order to look at how naturalisation requirements have evolved in different contexts. A fifth case study provides an overview of requirements in three Englishspeaking countries outside of Europe - Australia, Canada and the United States.

\section{BELGIUM}

Applicants for Belgian nationality are required to provide evidence of proficiency in one of the three official languages, Flemish, French or German, as well as prove evidence of 'social integration'. Belgium offers applicants a range of options to satisfy both the language and integration requirement, including through completion of an integration course. Integration courses are offered free of charge to migrants and include an element of information provision, language training and civic education.

The Belgian case is a good example of an approach that offers an integration course instead of an examination to satisfy requirements. However, it also highlights the challenge of ensuring a consistent approach, so that applicants undertaking courses organised by a range of local organisations are treated on an equal basis in applications. Other challenges identified by community organisations and course evaluations relate to the costs of accessing integration courses, such as transport and childcare costs, and the lack of provision for persons with low levels of literacy.

\section{FINLAND}

There are multiple options for meeting the language requirement in Finland. Applicants may take the test in oral and written Finnish; oral and written Swedish; Finnish sign language; or Swedish sign language used in Finland. The method for assessing deaf applicants' sign language skills has been highlighted internationally as good practice. Finland does not have civics requirement attached to naturalisation currently. EMN Finland (2020) commented that, typically, inadequate language skills are the most commonly cited reason for rejection of applications for citizenship, although failure rates are low (3.7 per cent in 2019).

\section{PORTUGAL}

While some language requirements were already present in Portugal in the 1950s, their current shape was defined in 2006 and re-defined in 2013. There are a number of ways to satisfy the language requirement. The tests can be taken in 
Portugal and abroad. Language testing in Portugal is based on the existing infrastructure - a network of testing centres in Portugal which use centrally developed exams.

Importantly, the individuals originating from a country with Portuguese as an official language are exempted from the test. Currently, this group constitutes the majority of naturalisation applicants. Another important feature found in Portugal is the existence of a free language course for foreigners. Graduating from the course is a proof of a language level sufficient for a citizenship application: no exam is required.

No civics requirement exists in Portugal.

\section{UNITED KINGDOM}

Until relatively recently the requirements related to naturalisation in the UK included only language. The system of requirements allows for testing in three languages; English, Welsh and Scottish Gaelic. The requirements in a more defined form are a more recent phenomenon and their development can be seen as a result of a quest for more integration in parts of migrant community. The debate on citizenship tests is more politicised in the UK than the other countries studied in detail.

Whereas the system of requirements has been relatively stable, its elements evolved over time. As for the language component, the 'double route' system (which included participation in a course leading to acknowledgment of language skills) was abandoned, and currently only the test possibility exists. The civics component of testing is based on the 'Life in the UK' handbook. The handbook was changed a number of times, including a change of focus from information related to day-to-day life to more history and culture-based knowledge. While many participants rated the information contained as useful, in some cases it was out of date. Private courses in the UK are quite expensive.

\section{AUSTRALIA, CANADA, AND THE UNITED STATES}

These three countries are often seen as role models when it comes to requirements related to naturalisation, being longstanding immigrant destination countries, yet these states' requirements significantly differ from each other. In Australia and Canada, tests are written; in Australia the same test is used for the language assessment. In Australia the content of the civics test was changed a number of times in response to criticism. In the United States, in turn, the civics test is performed by an immigration officer. The assessment is oral and an integral part of it concerns the language. The civics test in the US has been criticised 
regarding content and also for being very demanding, evidenced by the fact that test results are much higher for immigrants than citizens born in the country, prompting a debate on 'super-citizens'.

\section{POLICY IMPLICATIONS}

The introduction of language or civic requirements for naturalisation would represent a significant new direction for Ireland, and potential costs are considerable. The specific migration and policy context that has shaped language and civic requirements in other countries must be borne in mind when examining how such requirements operate. Nevertheless, the countries examined provide some valuable lessons for Ireland.

The introduction of a language requirement would require first considering the availability and accessibility of English language courses and supports currently in place in Ireland and their capacity to meet demand, should language acquisition be linked to citizenship. If a language requirement were to be introduced, regard should be given to providing applicants with the option to demonstrate proficiency in Irish and Irish Sign Language, with associated supports. Similarly, the format and content of any future civic requirements would also be important to consider, in light of opportunities for acquiring civic knowledge already in place, such as courses and information currently offered by the State and NGOs.

Research and guidance from international bodies underline the need for testing not to discriminate against candidates with special requirements, such as people with disabilities and people with low levels of literacy and formal education. Otherwise testing can exclude certain candidates from acquiring citizenship.

If such requirements were to be introduced, further research into the most appropriate and fair format for requirements, and their potential impact prior to their introduction would be essential. The views of people eligible to apply for citizenship and those who have become Irish citizens through naturalisation, as well as stakeholders such as employers, educators and the wider public, should be included in considering the introduction of any citizenship requirements in Ireland. Building in some form of evaluation of whether any requirements, if introduced, are meeting their stated aims would be best practice and strongly recommended.

A key question raised during this project was to what extent language and citizenship requirements lead to better integration outcomes. Due to the sparse information on the effect of measures adopted in European countries on the integration of migrants, it is difficult to reach any conclusions about the long-term 
effects of language and civic integration requirements linked to citizenship. That said, in terms of labour market integration, English language skills are clearly associated with both having a job and having a good job in Ireland (McGinnity et al., 2020). We would concur with Rocca et al. (2020), who argue that high-quality language assessments, for example, can support migrants if they are used to encourage and guide, according to real life needs and different abilities. However, if they are used to 'measure' integration or 'success in the integration process', this logic is largely unsupported by the evidence. While English language skills are key for integration outcomes, particularly in the labour market, attaching language requirements to citizenship may not be the most appropriate way to encourage language acquisition and other options such as ensuring widely available and accessible language courses in Ireland may be more effective. 


\section{CHAPTER 1}

\section{Introduction}

\subsection{CIVICS AND LANGUAGE TESTS FOR NATURALISATION}

Citizenship acquired by naturalisation may be viewed as the highest level of 'membership' potentially available to migrants in the host State. In the words of one commentator, it is 'the most valuable resource that mobile foreigners can ever hope to obtain' (Schuck, 2003). The acquisition of citizenship is itself viewed as a key measure to facilitate the integration of migrants in the host society (Department of Justice, Equality and Law Reform, 1999; Office of the Minister for Integration, 2008). Indeed, the proportion of migrants with citizenship of their host country was proposed as an indicator of how well Member States were integrating their migrant populations at the Ministerial Conference in Zaragoza in 2010, and is used in the Irish monitoring reports on integration (McGinnity et al., 2018).

Several European countries have opted to make the naturalisation of migrants contingent on language competence and/or civic knowledge or integration. Language and civic knowledge/integration requirements are not only linked to the acquisition of citizenship, but also increasingly form part of requirements for pre-entry procedures, residence permissions, family reunification and permanent residence (Strik et al., 2010). The motivation behind civics and language requirements is often stated to be linked to facilitating integration. The EU's Common Principles on Integration state that basic knowledge of the host society's language, history, and institutions is indispensable to integration, and enabling immigrants to acquire such knowledge is essential (Council of the European Union, 2004). However, there is great diversity in the approach to such requirements. Citizenship applicants may be required to complete an exam testing the acquisition of language and/or knowledge of the country. In some countries, requirements are instead linked to courses designed to equip migrants with the language, skills and practical information on rights and services needed to support their social, political and economic integration. Where requirements are supported by provision of opportunities for learning, they may promote integration as a two-way process, requiring an investment by both the migrant and the host society (Parliamentary Assembly of the Council of Europe, 2014).

However, the adoption of such requirements calls into question the concept of citizenship itself. An element of tiered citizenship may be created whereby naturalised citizens are required to 'prove' their credentials, while nationals by birth are not. The introduction of civics or country knowledge requirements also demands some debate and agreement on what it means to be a 'good citizen' and what information should be imparted to help migrants reach this goal. Again, 
citizens by birth may, or may not, hold the same knowledge. Much literature on citizenship requirements considers that language and civic requirements set exceptionally high barriers to secure settlement in host countries, and that certain States may use integration requirements as a further layer of control on permanent immigration (Carrera, 2006; Goodman, 2010; Strik et al., 2010; Pulinx et al., 2014; Wodak and Boukala, 2015; Joppke, 2017; Orgad, 2017). Civic and language testing may not be well designed for the specific needs of certain applicants and vulnerable groups, which increases the risk of discrimination, particularly towards persons who may be illiterate or have low levels of education (Parliamentary Assembly of the Council of Europe, 2014; Carrera and Vankova, 2019). Costs involved in preparing for, and/or taking, such tests, may pose an additional obstacle to migrants and may be discriminatory against those with low levels of income (Strik, 2013).

\subsection{ACQUIRING IRISH CITIZENSHIP}

What is the current situation in Ireland? Pursuant to Section 15 of the Irish Nationality and Citizenship Act 1956 (as amended), an applicant for naturalisation in Ireland must meet the following conditions:

- be 18 years of age, or a minor born in Ireland;

- be of good character; ${ }^{1}$

- have resided in the State for at least five out of the previous nine years, including one year of continuous residence prior to the application;

- intend in good faith to continue to reside in the State after naturalisation; and

- make a declaration of fidelity to the nation and loyalty to the State and undertake to faithfully observe the laws of the State and respect its democratic values. $^{2}$

The vast majority of naturalisation applications in Ireland are successful: for most years between 2010 and 2017 for example the refusal rate was less than 5 per cent of valid applications (McGinnity et al., 2018).

While naturalisation is based on legislation from the mid-1950s, for most of the twentieth century Ireland was a country of emigration, and so the issue of immigrants naturalising was not a marked feature of Irish society or public debate. This is in sharp contrast to countries like the UK or the US, which have a much discretion to decide what factors or criteria to consider when assessing an applicant's good character. Applicants are required to provide information in their application on any offences committed or criminal charges in Ireland or another country. The Department of Justice and Equality rely on reports from An Garda Síochána in assessing the good character of applicants.

2 Applicants are required to make the declaration before a judge of the District Court in open court, a citizenship ceremony, or other manner for special reasons allowed by the Minister for Justice and Equality. 
longer history of naturalisation and debates on who should be allowed to naturalise and under what conditions.

Ireland is one of nine EU Member States ${ }^{3}$ that do not currently require a citizenship applicant to provide evidence of civic knowledge or integration. Ireland and two other EU Member States do not require proof of language skills in an official language when applying for naturalisation. ${ }^{4}$ While not subject to significant debate to date in Ireland, the introduction of language and civic requirements has been considered in various policy contexts over the past decade. The drafts of an Immigration, Residence and Protection Bill published in 2008 and 2010, which were ultimately not enacted, included a requirement to demonstrate 'a reasonable competence for communicating in the Irish or English language' and 'reasonable efforts to integrate into Irish society' for long-term residence. ${ }^{5}$

An independent review commissioned by the then Office of the Minister for Integration and Department of Education and Science was undertaken in 2008 to assist in the development of a national English language policy and framework for adult immigrants in Ireland (Horwath Consulting Ireland et al., 2008). As part of the review process, a survey was carried out with institutions involved in the provision of English language training to immigrants or those with an interest in such provision. Of 98 organisations consulted, the report noted strong support for positive incentives and measures to promote language education, while most consulted were strongly against connecting language proficiency to citizenship. Strong support was also noted for the combination of English language training with education in carrying out essential administrative tasks such as communicating with authorities, filling out tax forms and accessing health care (Horwath Consulting Ireland et al., 2008).

Subsequently in January 2012, the then Minister for Justice, Equality and Defence, Alan Shatter, stated that a key priority for 2012 would be completion of work on the development of an English language/civics test for naturalisation applicants (McGinnity et al., 2012). ${ }^{6}$ The Minister expressed the view that the ability to:

speak the language... together with some knowledge of the way business is conducted in Ireland is an essential part of the integration process for

The nine EU Member States with no civic knowledge or integration requirement are Cyprus, Finland, Ireland, Italy, Malta, Poland, Portugal, Slovenia and Sweden.

The two other EU Member States that do not require proof of language skills are Cyprus and Sweden. Immigration, Residence and Protection Bill 2008, available at

https://data.oireachtas.ie/ie/oireachtas/bill/2008/2/eng/initiated/b0208d.pdf; Immigration, Residence and Protection Bill 2010, available at https://data.oireachtas.ie/ie/oireachtas/bill/2010/38/eng/initiated/b3810d.pdf.

6 Department of Justice and Equality, 'Immigration in Ireland 2011 - a year-end snapshot - major changes and more to follow. Minister Shatter outlines plans for 2012', Press release, 3 January 2012, available at www.justice.ie/en/JELR/Pages/PR12000001. 
immigrants and must form an integral part of eligibility for naturalisation. ${ }^{7}$

NGOs at the time expressed their concern that a citizenship test would need to be carefully devised (McGinnity et al., 2012). However, no developments on the introduction of such tests were subsequently reported that year (McGinnity et al., 2013). In 2013, in the Policy document on non-EEA family reunification, the Department of Justice and Equality expressed the view that it would be reasonable to incorporate a language requirement for family reunification cases and stated that the introduction of a language and knowledge of society and culture requirement for all migration routes would be examined (Department of Justice and Equality, 2013).

Ireland's Migrant Integration Strategy 2017-2020 noted that citizenship tests featured during the Strategy's consultation process, with some commentators of the view that citizenship tests should be introduced and others opposing their introduction (Department of Justice and Equality, 2017). Action 12 of the Strategy states that the introduction of both civics and language tests for those seeking citizenship will be examined (Department of Justice and Equality, 2017; 2019).

\subsection{STUDY AIMS}

This research study, carried out on behalf of the Department of Justice and Equality, aims to contribute to such an assessment by investigating practices elsewhere in Europe. The study first maps policies and practices on civics and language requirements in all EU Member States and the UK (Chapters 2, 3 and 4), focusing on where such requirements are directly linked to the naturalisation process. The second part (Chapter 5) considers in more detail five case studies of particular interest. An in-depth analysis of the content of civics and language requirements is beyond the scope of this study. Instead our primary focus is to provide a fuller understanding of the evolution of such requirements in these countries, the reasons for their introduction and the way in which such requirements operate in practice. The study thus combines a broad overview of European countries with an in-depth understanding of how and why these policies were introduced in selected case studies. What are the key learning points for Ireland? Does evidence suggest that these requirements facilitate integration or enhance integration outcomes? The concluding chapter draws out lessons from the study about the challenge of introducing language and/or civics requirements for those seeking citizenship in Ireland.

Department of Justice and Equality, 'Immigration in Ireland 2011 - a year-end snapshot - major changes and more to follow. Minister Shatter outlines plans for 2012', Press release, 3 January 2012, available at www.justice.ie/en/JELR/Pages/PR12000001. 
This report looks at requirements which are related to citizenship acquisition only. It should be stated, nevertheless, that while the use of language and civics requirements is most common at naturalisation stage among the countries examined, in several countries civic and language requirements are applied at earlier stages - that is during an application for permanent residence, temporary residence or even before entering the territory of a host state (Strik et al., 2010; Rocca et al., 2020). In principle, the level of requirements increases along the category of residence and rights granted. The relationship between these stages is not straightforward due to the progressive nature of requirements in some countries. In the discussion of requirements in EU Member States and selected case studies in Chapters 3, 4 and 5, links are made to requirements in earlier stages where possible.

\subsection{METHODOLOGY AND CASE STUDY SELECTION}

The research was conducted from February to April 2020. Desk research was undertaken at the outset, including a review of existing international academic and policy-based literature. A mapping exercise was undertaken to gather information on the language and civic requirements for naturalisation applicable in all $27 \mathrm{EU}$ Member States and the UK. National legislation, policy documents, reports and literature relevant to each country were examined. The research was complemented by information gathered for the European Migration Network (European Migration Network, 2020) study on Pathways to citizenship for thirdcountry nationals in the $E U$, which includes some information on language and civics tests linked to naturalisation.

This report presents four European case studies - Belgium, Finland, Portugal and the United Kingdom - as well as a fifth case study providing an overview of requirements in three English-speaking countries outside of Europe; Australia, Canada and the United States. In selecting case studies, the overarching aim was to focus on countries with significant potential for learning in Ireland. We looked for countries with commonalities with Ireland, for example in terms of population size, host-country language (English), migration history and profile of the migrant population. In particular, it was considered important to include countries that have more than one official language in order to determine how language requirements in such countries are implemented. We also sought diversity among the case studies in order to look at how naturalisation requirements have evolved in different contexts. Finally, we looked for particularly interesting practices to investigate further. The United States, Australia and Canada were included briefly as English-language speaking settler countries with a much longer tradition of civics and language testing. 
Like Ireland, Belgium, Finland and Portugal are relatively small European Member States. All four European countries studied, along with Ireland, reached a historical peak in the share of foreign-born in the population in 2018: Belgium 16.8 per cent; Finland 6.8 per cent; Portugal 10.2 per cent; and the United Kingdom 13.8 per cent. Goodman (2010) groups Ireland, along with Belgium, Finland and Portugal, as countries that 'enable citizenship', arguing that citizenship is viewed in these Member States as a mechanism for establishing equal status and rights, thereby enabling instead of rewarding integration. This position is contrasted with the 'conditional citizenship' observed in the Netherlands, France and UK. Here it is argued, comparatively liberal criteria of citizenship eligibility combine with arduous civic requirements, to mean that citizenship is viewed as a reward not a mechanism for integration. ${ }^{8}$ In Belgium, Finland and the United Kingdom, there is a recognition of more than one language as a (regional) official language. Such multilingualism requires specific coordination efforts.

Naturalisation requirements evolved in the four European case study countries in very different contexts. With respect to migration history, three of the countries selected (Belgium, Portugal and the United Kingdom) were colonial powers and receive significant flows from former colonies, while Finland is an exception in this regard. The countries also differ with respect to how recent or well-established migration flows are. As discussed, in Finland and Portugal the current migration situation results from relatively recent developments. In Belgium and the UK the migration flows are more established. In 1950 the share of the foreign-born population in Belgium was already 4.3 per cent, whereas in Portugal it was 0.2 per cent, in Finland 0.3 per cent and in the UK 0.8 per cent (Bonifazi and Strozza, 2001). Finally, while Belgium, Finland and Portugal belong to a group of countries with a higher than OECD average rate of naturalisations, the UK remains slightly below this average. The combination of these factors points to the diversity of contexts in which naturalisation policies take place. Importantly, as this report will demonstrate, there is no single answer to such diversity; while this might be a valuable message itself, from a policymaking perspective it is relevant to present and analyse different approaches to requirements related to naturalisation.

Finally, we looked for particularly interesting practices. In 2015, the Migration Policy Index (MIPEX) ranked countries according to access to nationality. Highestranked countries include those in which the requirement to pass a basic language test and a citizenship course encourages an applicant to succeed through free, flexible and professional courses and tests. Portugal ranked first as most 
favourable, followed by Sweden, Germany, Belgium, Luxembourg, Netherlands, Finland, France and UK; Ireland was ranked $14^{\text {th }}$ (Huddleston et al., 2015). As will be discussed in Chapter 5 unlike most other countries that require applicants for naturalisation to take a civics/integration test, Belgium offers a range of options to satisfy 'integration' requirements, one of which is an integration course freely available to immigrants. Completion of the course, as opposed to a test, is the requirement.

Following the selection of case studies, requests for information and interviews were issued to officials and country experts based in the four countries selected. The EMN national contact points of Belgium, Finland, Portugal and the UK provided assistance in making contact with national officials responsible for policy on citizenship. Information and data, where available, were obtained in writing from officials of the Nationality Division of the Belgian Federal Public Service for Justice and the Nationality Unit, Legal and Support Services, of the Finnish Immigration Service. Phone interviews were undertaken with an official of the Passport and Nationality Policy Unit of the Borders, Immigration, Citizenship System, Policy and International Division of the UK Home Office, and Patrícia Jerónimo, Associate Professor at the Faculty of Law of the University of Minho, Portugal and country expert for Portugal for the GLOBALCIT Observatory of the European University Institute.

\subsection{REPORT STRUCTURE}

Chapter 2 examines the context for citizenship. It briefly discusses debates about the concept of citizenship in the context of migration, and how this informs policies governing who can acquire citizenship and under what conditions. A particular focus of this report is language and knowledge of society requirements for citizenship. It also presents the profile of migrants in EU Member States in terms of their overall share in the population, reasons for residence of non-EU nationals, employment rates and citizenship acquisition patterns, setting Ireland in comparative perspective. Chapter 3 provides an overview of language requirements in the context of citizenship in EU Member States and the UK. Chapter 4 provides an overview of knowledge of society or integration requirements for citizenship applicants, if any. Chapter 5 includes case studies on Belgium, Finland, Portugal and the UK, in addition to a brief overview of language and civic requirements in Australia, Canada and the United States. Chapter 6 concludes the study and looks at policy implications for Ireland in light of the overview of EU Member States and case studies. 

CHAPTER 2

\section{Approaches to citizenship, naturalisation requirements and migrant populations in Europe - an overview}

\section{$2.1 \quad$ INTRODUCTION}

This chapter has two main purposes. First, it introduces the main debates on citizenship in the context of migration. The concept of a 'civic turn' is discussed, which refers to the introduction of language and civic requirements for residence and citizenship in several EU Member States. The chapter also explores the meanings of citizenship, its value to individuals who can apply for it and reasons why they do so. While the debate on citizenship might be seen as academic, its conclusions have direct consequences for citizenship policy and guide questions on who should be included in a national community, whether requirements should be introduced and, if so, what kind of knowledge or values this person should be asked to demonstrate. In short: who belongs, or ought to belong, to the national community (Orgad, 2017). Setting the boundaries of citizenship in any country requires difficult decisions about who 'we' are and what kind of community 'we' want to be.

Second, in the remainder of the chapter, comparative data on the profile of foreign-born individuals in the EU are presented, as well as some indicators of integration. The motivation for providing such a broad overview is the view expressed by some researchers (Joppke, 2007) that civic and language requirements, including those related to naturalisation, have been introduced as a response to an 'integration crisis'. Compared to other European countries, we show that Ireland performs relatively well in this respect.

\subsection{NATURALISATION REQUIREMENTS AND THE 'CIVIC TURN'}

Language and civics or 'knowledge of society' requirements have become more common in granting migrants various types of residence status among Member States of the European Union. While in the majority of the states, requirements are applied to permanent residence or naturalisation applications, in countries such as the Netherlands, some requirements need to be met even before entering the territory. Furthermore, the increased mobility of EU citizens to other Member States following EU enlargements in 2004 and 2011, as well as the overall increase in immigration of non-EU nationals to the EU for work, education and protection, has also contributed to the discussions on the need to integrate migrants into host societies. For policymakers, the introduction of such requirements is seen as a way of promoting or assuring integration with a host society; a person who passes a test is seen to have knowledge of the language, and some cultural norms prevailing 
(or defined as prevailing) in a given country. Some observers (Etzioni, 2007; Van Oers, 2014), nonetheless, perceive the emergence of requirements as a means of regulating the acquisition of citizenship and in some cases, reducing possibilities to reside on a permanent basis. Indeed Joppke (2017) argues the recent focus on 'civic integration' is a merging of integration policy with immigration control.

The most advanced form of recognition of foreign-born individuals by a host society is naturalisation, that is granting citizenship based on proof of residence for a given period and evidence of meeting other conditions, such as knowledge of language, knowledge of society and lack of a criminal record. The status of citizen is linked to some duties (e.g. military service, sitting on a jury board), but also several unique privileges like the right to non-expulsion from the host country, the right to reside and the right to vote.

The introduction of requirements in several European countries has been interpreted by many researchers as evidence of a 'civic turn' in migrant integration policy (Joppke, 2007; Goodman, 2014; Borevi et al., 2017). The reason for talking about a 'turn' rather than 'convergence' lies in the absence of such requirements until recently on the one hand, and the diversity of newly introduced policy approaches on the other. The resulting integration and citizenship policies have not been overhauled to a large extent, rather, citizenship requirements have created an additional pillar of these policies. This section is concerned with identifying why the 'civic turn' has been observed in Europe and how we can locate Ireland in this discussion. According to the literature, such reasons can be grouped into two categories - responses to a 'problem pressure' ('insufficient integration of immigrants' in economic and social life) as well as reasons rooted in politics (Goodman, 2014).

Joppke (2007) presents several factors as contributing to the civic turn. They include the characteristics of the migrant population in the receiving countries, especially in relation to integration, but also taking account of broader political factors. These factors will be discussed below in light of the empirical material, in order to illustrate the position of Ireland vis-à-vis other EU countries, in some of which integration debates are particularly heated.

The growing importance attached to civics and language requirements is often associated with the specific migration population in a given country and the growing share of non-EU nationals in naturalisations, or low employment rates among the migrant population. The process of preparation, leading to the granting of citizenship (e.g. passing related tests) might be thus seen by policymakers as an integration exercise itself. 
Yet as Winter (2018) discovers when interviewing recently naturalised Canadian citizens, testing as part of the naturalisation process is differentiated by social class and education - even more than along ethnocultural grounds - rewarded those who have the skills to easily 'pass the test'.

More recent research by Joppke (2017) summarises the debates on citizenship requirements and the 'civic turn' by making three points. First, he claims that the introduction of civic requirements in several countries does not mean an end to the national models of integration. Second, he asks whether the introduction of civic requirements represents a retreat from multiculturalism. The answer is not simple; to start with, there is a general question as to whether multiculturalist policies existed at all. Further, while civic requirements can have some antimulticulturalist ingredient, they are only a part of wider integration agenda in each state where local and national policies interact. Finally, he analyses the issue of citizenship requirements from the perspective of a revival of assimilationist policies. He argues that a majority of policies reflect a liberal spirit in the sense of building knowledge about various aspects of a host society rather than creating uniform national identity among migrants.

\subsection{DIMENSIONS AND MEANINGS OF CITIZENSHIP FROM A MIGRATION PERSPECTIVE}

This section presents the contemporary interpretations of citizenship and sheds some light on the very fundamental issue: what does it mean to be a citizen of a given country? The context of migration amplifies the understanding of what citizenship entails; on the one hand because of the already mentioned right to move and return. On the other hand, migration challenges the traditional notions of a homogeneous community sharing a certain history and a set of values, as both sending and receiving societies are affected by processes of cultural influence (cosmopolitanism, multiculturalism and transnationalism) (Van Den Anker, 2010). Bauböck comments on this issue: 'citizenship marks a distinction between members and outsiders based on their different relations to particular states' (Bauböck, 2006, p. 15). In the debate on citizenship, several authors point out a number of factors or dimensions that constitute citizenship (Bauböck, 2006; Brubacker, 1992; Honohan, 2017, Koopmans, 2005). Bauböck analyses citizenship by considering three dimensions: legal status, membership and rights. In this section, we follow Bauböck's (2006) approach. ${ }^{9}$ 
From the legal status perspective, citizenship is a 'sorting device' which allocates individuals to a specified sovereign state and creates a legal bond which specifies the rights and duties between the two. Citizenship therefore relates to a right of (re)admission to a country of own nationality (including those who inherited this status). Nationality can also be related to free admission to other states while restricting access to others, for example acquiring Irish citizenship permits freedom of movement within the EU. ${ }^{10}$

A second dimension of citizenship involves membership. Therefore it departs from individual's identity and focuses more on his/her relations and ties with others in society in social, cultural, economic and political terms.

The third dimension is rights. There is a large and growing body of literature on the contents of citizenship founded upon T.H. Marshall's (1950) work. Marshall differentiated between three types of rights: civil, political and social. The discussion about these three types of right is particularly relevant in the context of immigration and leads to some important questions.

How do different migrant statuses regulate access to these three dimensions of citizenship (legal status, membership and rights)? As argued by Bauböck, some rights can be claimed even by irregular migrants as they stem from inalienable human rights. Yet many other rights are deduced from the very fact of legal residence and the difference between regular and irregular residence might result in the different extent of available rights. Especially in the field of social rights a significant extension for legal migrants has taken place over recent decades. Yet, in the European context, big differences remain with respect to non-EU citizens and EU citizens residing in another EU Member State. The latter group enjoys considerably more rights as compared to non-EU citizens.

Finally, the question of rights is often contrasted with that of duties. If one goes beyond the duties which rarely occur (such as jury service) or fade with time (e.g. mandatory military service), most rights are linked to residence and to performing work. Such duties involve paying taxes and other contributions, participating in compulsory education etc. However, an increasingly important set of duties of migrants concerns the requirement to integrate into their host society. In a growing number of countries certain categories of migrants are requested to attest their language skills and the knowledge of society, culture and political institutions in a host state. Orgad (2017) argues that some naturalisation policies are aimed at protecting different forms and expressions of the national culture, a sort of 
'cultural defence policy', though this has been contested. These issues constitute the core of this report with respect to naturalisation, but also other aspects of residence in host countries.

To summarise, citizenship encapsulates a number of concepts, meanings and dimensions which are deeply embedded in each state's legal, cultural, social and economic order. From a more practical point of view, citizenship policies might be seen as a 'series of policies that make it easier or more difficult for immigrants to naturalise, and for their children to become citizens at birth' (Goodman and Howard, 2013).

\subsection{DRIVERS OF NATURALISATION DECISIONS}

The overview of topics related to citizenship leads to a fundamental question: why should migrants claim citizenship of another country? And why should states grant citizenship to migrants? First and foremost citizenship provides security of residence, particularly in the EU for non-EU nationals. It typically confers work rights that do not rely on a special permission or permit. In some states, family reunification procedures are significantly simplified if a sponsor (family member already residing in the host country) has citizenship of the host country. Further, in several democratic states, citizenship is intrinsically linked to the possibility of participation in political life - both active and passive voting rights. Thus, from this perspective, citizenship can be seen as beneficial for migrants, however, as the following paragraphs demonstrate, the decision to naturalise depends on a number of factors.

So which migrants naturalise? Dronkers and Vink (2012) analysed the propensity to naturalise among migrants from different backgrounds. Their results obtained by the analysis of the European Social Survey data for $15 \mathrm{EU}$ countries indicate that, in general, citizenship policies have an impact on citizenship acquisition. Therefore the obstacles to citizenship might hamper the propensity to naturalise. However, individual characteristics of immigrants play a role as well. Second-generation immigrants and first-generation immigrants with a long period of stay in a receiving country are more likely to acquire citizenship. Also, citizenship acquisition is more probable among immigrants with one parent born in the host country, retired workers and individuals speaking the language of the host country at home. Significantly, neither employment nor education statuses played an important role.

This research has also shown that the unfavourable economic situation and the political instability in a country of origin plays a role for the decision to naturalise, and thus migrants might value citizenship depending on their origin. In the 
European context, a differentiation between EU and non-EU individuals in their naturalisation decisions can be found. Accordingly, non-EU nationals tend to have a higher propensity to naturalise in general and base their decision on the grounds of the economic situation in their host countries (but also on what benefits are associated with having a 'good passport'), whereas their EU counterparts base their decisions on their attachment to the host country (ibid.). For example, as Reichel and Perchinig demonstrate for Austria, holding EU citizenship is a strong predictor of the decision not to naturalise (Reichel and Perchinig, 2014). The research by Paparusso on six European countries is consistent with this, but provides more nuance to the understanding of the decision to naturalise (Paparusso, 2019). The research found migrants from Sub-Saharan Africa and Latin America have the highest propensity to naturalise, followed by Eastern Europeans, with migrants from the Middle East and North Africa least likely to have citizenship status in the countries examined. Migrants from a country which was a former colony of the country to which they migrated also appear to be more likely to become citizens. Further, the length of stay in a host country increases the probability of naturalisation. Also, migrants who arrived in a host country as children tend to naturalise more when compared to those who migrated as adults. Individuals who migrate on the basis of family reunification show a high probability of naturalisation, followed by those who migrated on humanitarian grounds (ibid.). Kostakopoulou, on the other hand, argues that from the state's perspective, granting citizenship to non-nationals is a matter of increasing their allegiance to their host country (Kostakopoulou, 2001).

Further, Joppke (2010) argues that several states have witnessed an emergence of 'citizenship light'; that is a status where citizenship is no more the main gateway for enjoying a plethora of rights. In Joppke's words, citizenship light is:

easy to access, whose rights do not go much beyond the rights that many non-citizens already enjoy, and whose identity is thin and procedural, incapable of sharply setting apart one nation-state society from other such societies (Joppke 2010a: 12).

In some European states, permanent residence status opens access to the majority of rights, particularly socio-economic rights, and thus the additional advantage of acquiring citizenship is minor. While topical in other European countries, this is not the case in Ireland, as there is as yet no long-term residence status enshrined in law, and applications for long-term residence, which can only be made on the basis of an administrative scheme, are very low (McGinnity et al., 2018). Indeed MIPEX ranks Ireland as $35^{\text {th }}$ out of 38 countries on access to permanent residence (Huddleston et al., 2015). That said, it is useful to bear in mind that for some countries, tests are applied at an 'earlier stage' of the process. 


\subsection{A PROFILE OF MIGRANT POPULATIONS IN EU COUNTRIES: IRELAND IN COMPARATIVE PERSPECTIVE}

The previous section set the scene regarding meanings of citizenship in modern societies and debates surrounding naturalisation. Also, possible drivers of naturalisation among different migrant groups were presented. The current section explores in more detail the background to the introduction of civic and language requirements related to naturalisation. One of the main arguments made in the research concerns a perceived unsatisfactory integration of migrants which may be seen as a 'problem pressure' to which a number of states have responded. This is why the following section first presents the size of migrant populations from different perspectives in European states, followed by EU-wide comparisons of a number of dimensions related to integration.

This section provides a brief empirical illustration of these phenomena and locates Ireland in this landscape. This comparison is conducted for the Member States of the European Union. ${ }^{11}$ It looks at the population data, related to stocks and flows of migrants, labour market situation of this group as well as educational outcomes.

\subsubsection{Size and composition of immigrant populations in European countries}

As mentioned in the opening sections of this chapter, the acquisition of citizenship by a migrant is viewed by some Member States as the crowning of the integration process, while in other Member States citizenship is itself viewed as part of the integration process. Figure 2.1 presents EU-wide data on citizenship acquisition. When it comes to acquisitions themselves, there is a striking difference in the composition of migrants who receive citizenship. Only in two Member States, Hungary and Luxembourg, were most new citizens nationals of other EU countries. In the remaining states non-EU nationals constitute the majority of those naturalised. Countries of Eastern Europe as well as Southern Europe report the highest share of non-EU citizens who naturalise. In Ireland, the share of EU and non-EU nationals among those who naturalise is more even, with 47.5 per cent of those gaining Irish citizenship in 2018 being citizens of other EU countries, though the proportion of EU citizens acquiring citizenship has not always been so high (see Barrett et al., 2017). 
FIGURE 2.1 THE DISTRIBUTION OF CITIZENSHIP ACQUISITION IN EU MEMBER STATES BY ORIGIN, 2018

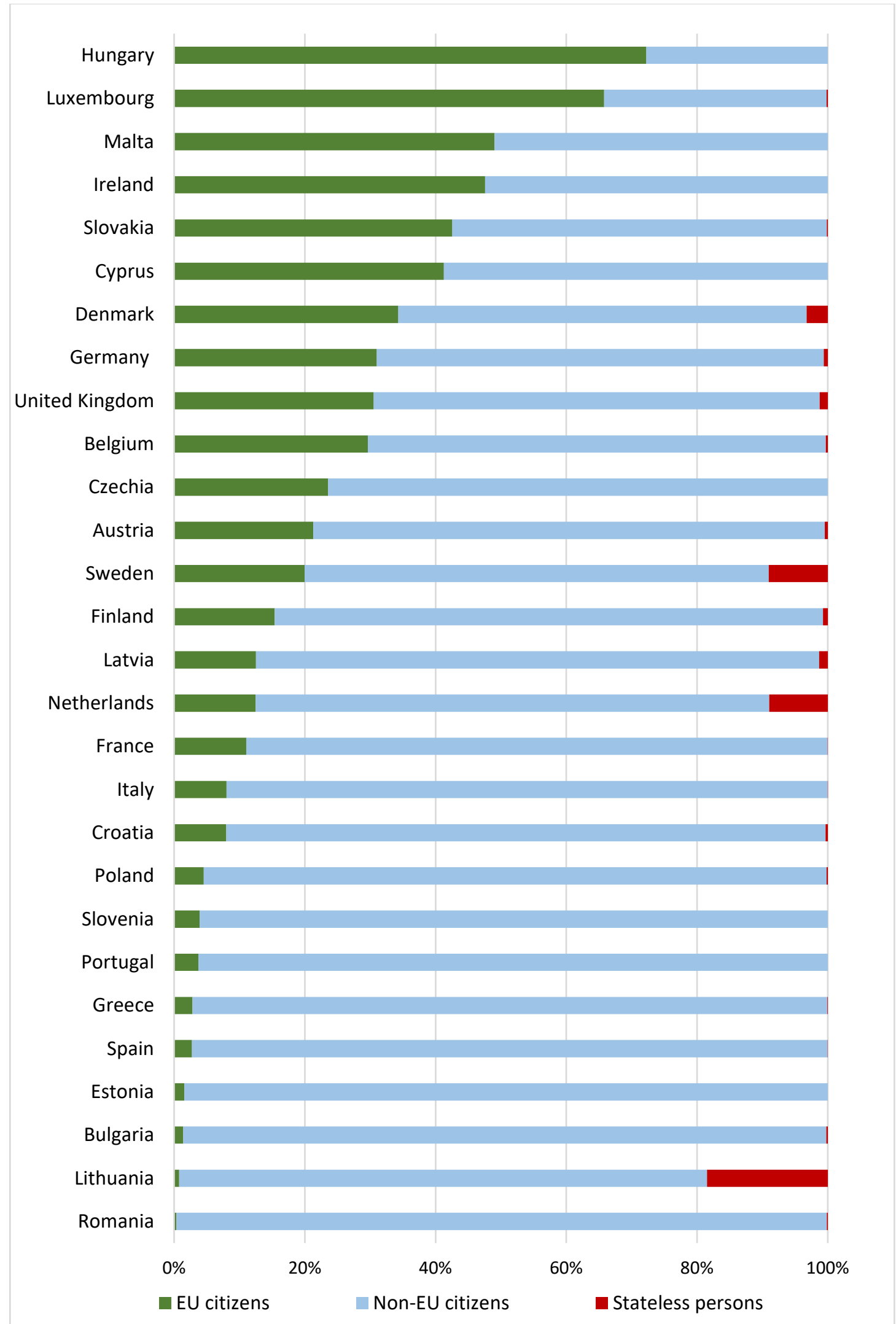

Source: Eurostat, [migr_acq], https://bit.ly/3i7lRme, own compilation. 
Continuing with more general indicators of migrants in EU Member States, it should be stated first that the European Union is very diverse when it comes to non-citizen residents. Figure 2.2 illustrates the share of non-citizens in EU Member States. In 2018, the share of the population with a citizenship different to that of the host country ranges from less than 0.6 per cent in Romania to as much as 48 per cent in Luxembourg. Almost 12 per cent of the Irish population is of foreign citizenship, which is relatively high compared to other EU Member States. The most recent estimates from the Central Statistics Office indicate that 12.7 per cent of residents in Ireland were non-Irish nationals in 2019. Non-EU nationals constituted 3.4 per cent of the population residing in Ireland (CSO, 2019).

FIGURE 2.2 SHARE OF NON-CITIZENS IN THE EU MEMBER STATES' POPULATIONS, 2018

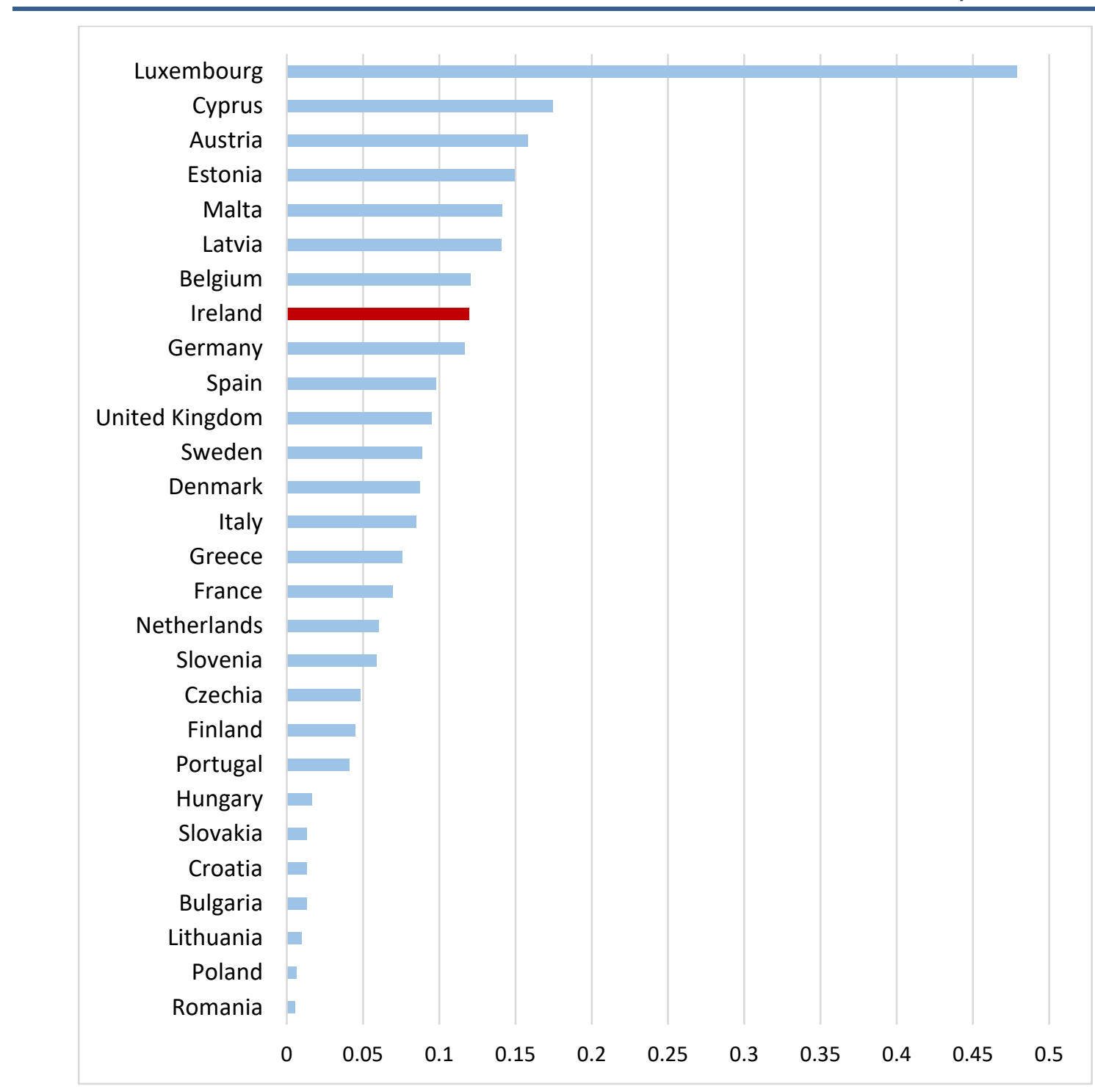

If one looks in more detail at the composition of the foreign-born population, Ireland has a very high share of EU citizens, which constitute three-quarters of all 
foreign-born residents in Ireland (Figure 2.2). As shown in Figure 2.3, the share of EU-born residents is highest in the case of Luxembourg, but Ireland falls close to Cyprus and Slovakia in fourth place. The states with the lowest shares of EU-born citizens in the foreign population are Latvia, Estonia and Poland.

FIGURE 2.3 SHARE OF FOREIGN-BORN EU CITIZENS IN EU MEMBER STATES, 2018

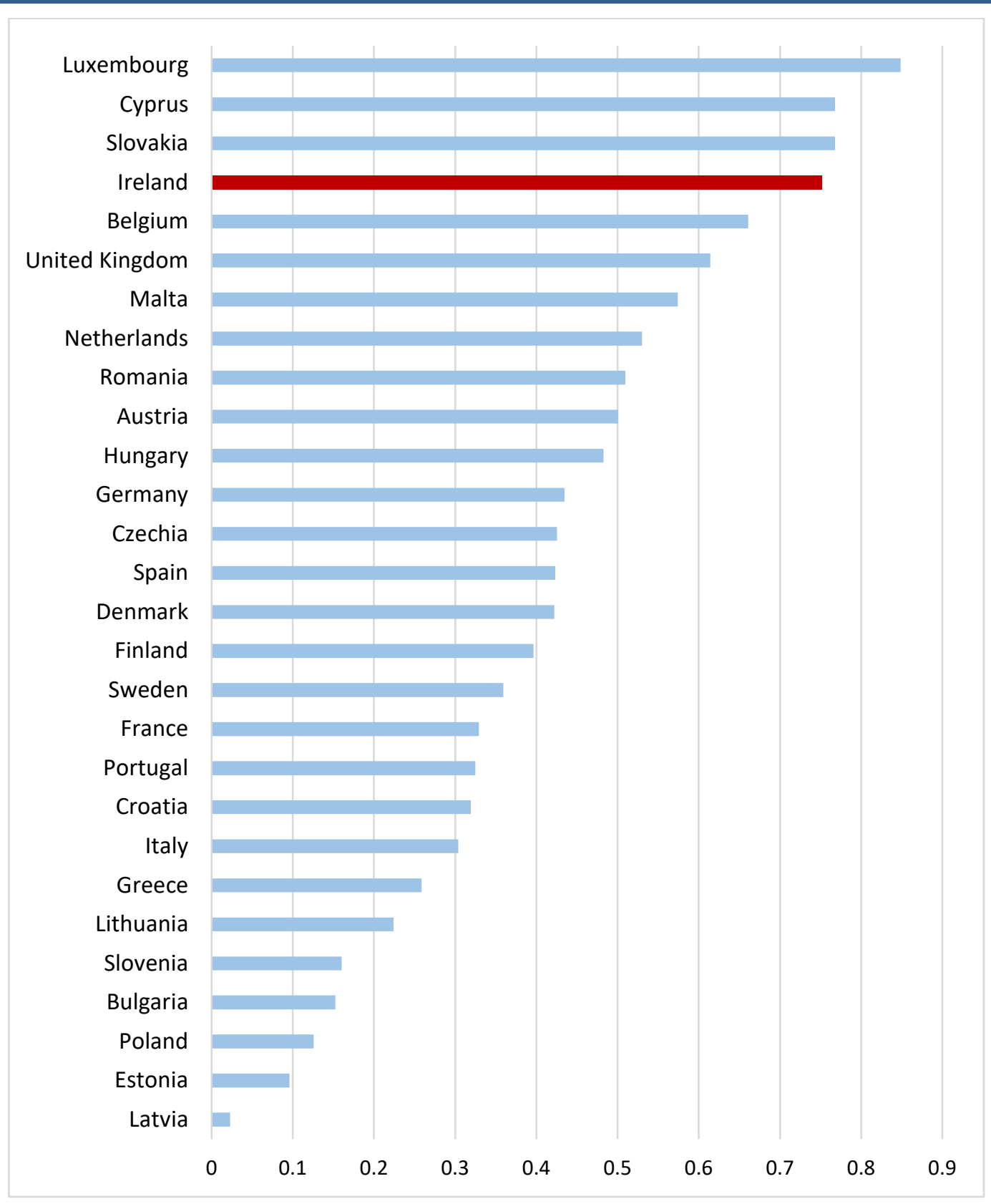

Source: [migr_pop1ctz], https://bit.ly/3hZRpKU, own compilation

Joppke (2007) contends that the rise of the civic turn in several states could be associated with a growing number of immigrants in Europe. This trend brought the issue of integration to the top of the agenda in some Member States. Experience tells us that the type of migrant in most demand by European governments is the economic migrant. Other categories, such as individuals looking for international 
protection and beneficiaries of family reunification programmes, often with lower educational attainment, have been identified by some Member State governments as in more need of integration support. This is why the distribution of residence permits by reason is presented.

As far as the purpose of non-EU nationals' stay is concerned (reasons for residence permits issued to non-EU nationals), Figure 2.4 distinguishes between four broad categories: family (reunification), education, work and refugee and subsidiary protection. Typically education permits are temporary, and people are expected to leave after they finish their education; ${ }^{12}$ family reunification refugee status and other protection statuses are supposedly permanent. Work permits could indicate either a temporary (circular) migration or an intention to settle.

Among the EU Member States Ireland has the highest share of permits issued in 2018 for the purpose of education; 30.7 per cent whereas the EU28 average is 5.8 per cent. The other area where Ireland ranks high is employment: 21.7 per cent permits were issued for this reason with the EU28 average at 15.8 per cent. It should be noted that, in principle, some of the reasons - such as education or work reasons - might be more short-term whereas family reunification or international protection reasons have a more long-term character. From this perspective, the situation with respect to integration challenges in states with high shares of employment and education-related permits might be significantly different to those where family and international protection reasons play a more important role.

12 Though Ireland allows students with an honours degree or higher to remain in the State for 12 to 24 months after their studies to look for work under the Third Level Graduate Programme; this is uncommon among EU countries (Groarke and Durst, 2019). 
FIGURE 2.4 THE DISTRIBUTION OF ALL VALID RESIDENCE PERMITS FOR NON-EU NATIONALS IN EU MEMBER STATES BY REASON, 2018

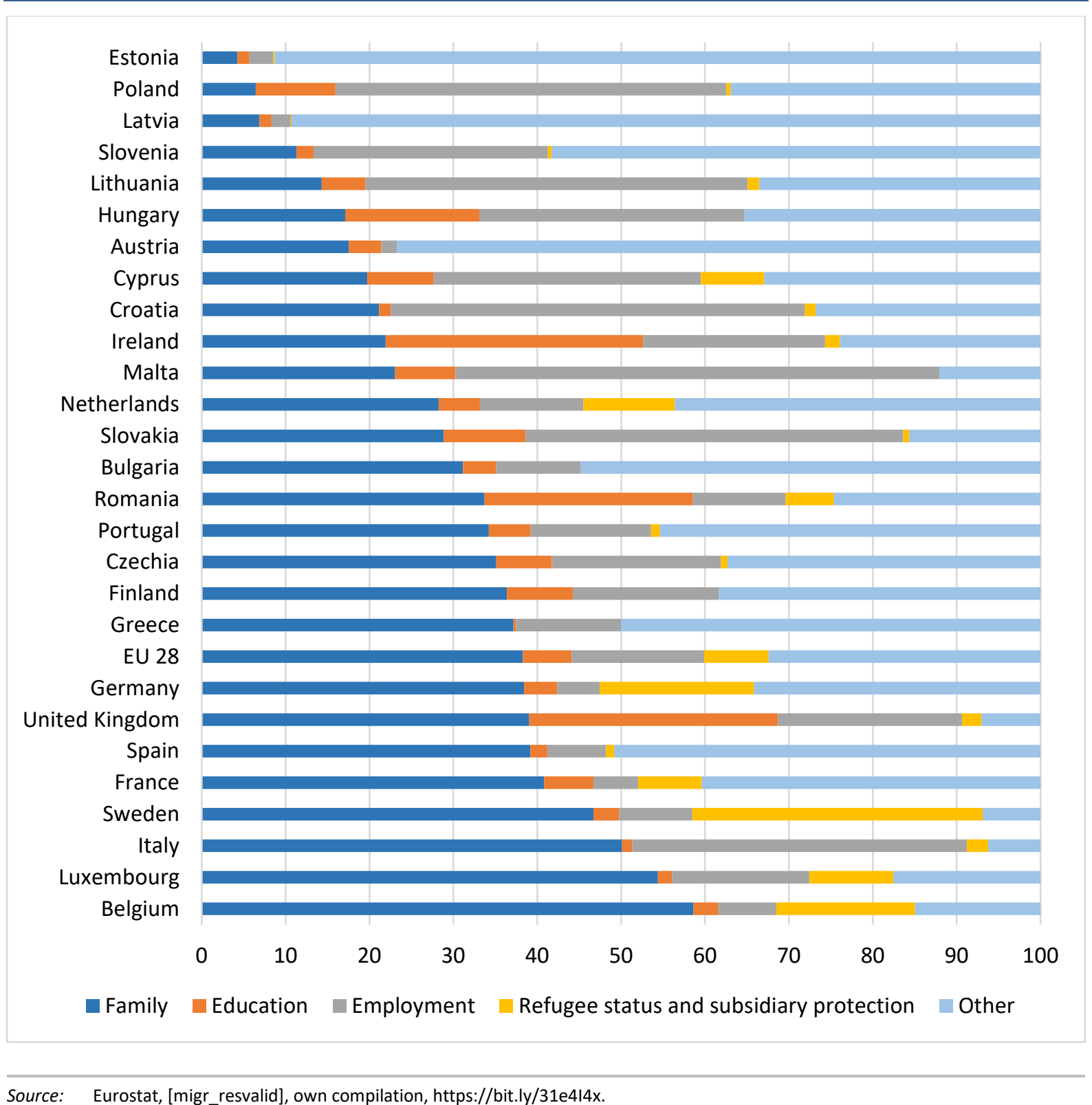

As can be seen in Figure 2.4, in Member States such as Germany, United Kingdom, Spain, France, Sweden or Italy, the share of permits issued on the basis of family reunion constitute roughly 40 per cent to 50 per cent of all permits. Together, these countries issued almost three-quarters of all valid residence permits in 2018.

Ireland has one of the highest proportions of education related permits. The position of Ireland in the rank is even higher when one looks first-time permits issued in 2018. In this case, more than 60 per cent of all first-time permits were issued for the purpose of education. This is by far the highest share of permits issued for education reasons by Member States in the EU (EU28 average: 20 per cent). As the issue of labour market activity plays a major role, the following paragraphs will be devoted to this topic. 


\subsubsection{Labour market situation of migrants}

Joppke (2007) argues that the 'integration crisis' and 'integration failure' has been seen through the prism of low employment rates and higher unemployment or inactivity among migrants as compared to native populations. Some of the statements he refers to can be supported by public opinion surveys. For instance, the most recent Eurobarometer survey, conducted in 2017 demonstrates that in the Netherlands, Sweden, France, Germany or Sweden (EU Member States with a longer history of immigration), there is a strong feeling of failed integration as 50-70 per cent of respondents believed this to be the case. In contrast, as little as 18 per cent of the respondents in Ireland think that integration of immigrants has not been successful. Eighty per cent of respondents in Ireland see migrant integration as a success, which is the best score on this dimension of any of the countries. Whether or not this is a correct assessment of the situation, the point is that integration is not perceived to be a problem by the general population.

The topic of economic activity takes a central place in the debate on the integration of migrants in host societies. Looking at the European averages, two phenomena can be noted. First, the employment rate of EU citizens born outside of host EU states is higher by approximately 5.8 percentage points than that of the host society. Second, the employment rate of non-EU nationals is lower when compared to the host country nationals (with a difference of 10.3 percentage points). The difference between the native and non-EU individuals' employment rates is the biggest in Sweden, where it exceeds 26 percentage points. Ireland fares well on this dimension - the employment rate gap between non-EU and Irish nationals is small at only 3.6 percentage points, while employment rate of other EU citizens is higher by 8.1 percentage points. 
FIGURE 2.5 THE EMPLOYMENT RATES OF THE NATIVE POPULATION, NON-EU AND EU MIGRANTS, Q3 2019

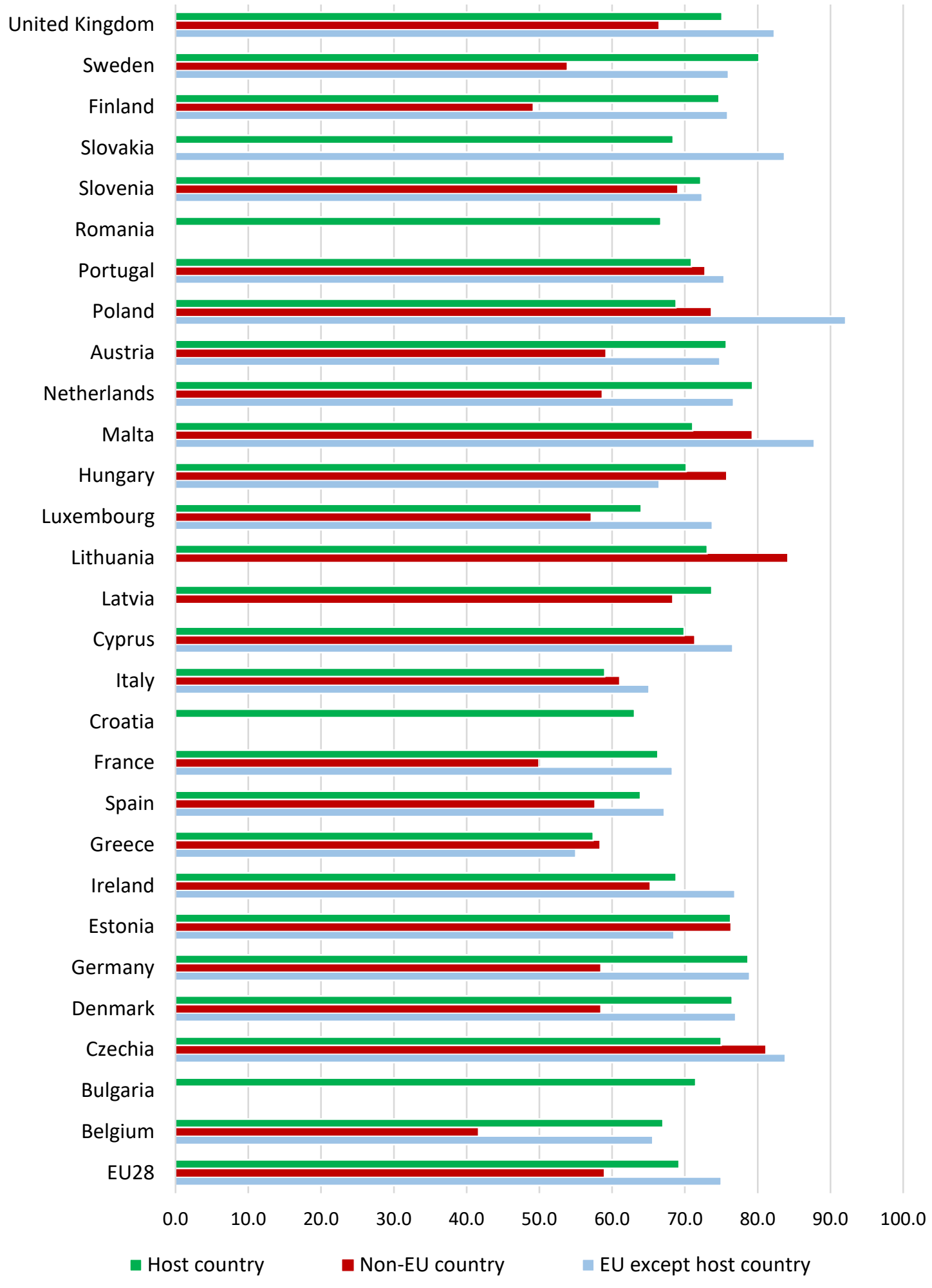

Source: Eurostat, [lfsq_ergan], https://bit.ly/3if2Pe2, own compilation. Data are missing where no value is shown.

In terms of the regulatory frameworks which govern the flows of migrants in the EU countries, the major differentiation is between EU citizens and non-EU citizens. 
When it comes to the former group, Article 20 of TFEU grants them unrestricted mobility within the EU. A special case in this respect was the introduction of the Transitory Agreement affecting individuals from the 2004 and 2007 enlargement Member States (Central and Eastern Europe) which temporarily prohibited workers from these countries from entering the majority of labour markets. The countries which did not apply the Agreement were Ireland, United Kingdom and Sweden, so Central and East European nationals could work immediately after enlargement in these countries.

The conclusions which can be drawn from such a comparison of employment rates are the following. An important share of EU citizens moves between Member States for the purpose of gainful employment which contradicts the notion of 'welfare tourism' (Doyle et al., 2006). As for non-EU nationals, their migration stories are more complex and, in some countries, economic migration might constitute a minority of flows.

An important note should be added here. As shown above, in some European states, the share of beneficiaries of international protection and individuals covered by family reunification programmes is quite sizeable. The research shows that the employment rates of these groups remain low even ten years after arrival. Yet it has to be emphasised that by definition these are not economic migrants, and their skillset, language proficiency and reasons why they leave their home countries differ (Papademetriou and Benton, 2016). The recent study by EMN on the labour market integration of non-EU nationals emphasises a number of integration challenges in this field (Arnold et al., 2019).

\subsubsection{Educational attainment and achievements}

Finally, indicators related to educational attainment and school performance are essential proxies of integration (Huddleston et al., 2013). According to a recent OECD study (2018a), Ireland is clustered in a group of states which are recent destination countries with many immigrants. However, while Spain, Italy, Portugal or Greece also belong to this group, their migrant populations display low levels of education. Ireland, along with Iceland and Malta have migrant populations characterised by high levels of educational attainment, but also on several other dimensions they score on par or better than migrant populations in other OECD countries. Such results for Ireland might be associated with the presence of EU citizens who report high levels of educational attainment overall, as well as Ireland's economic immigration policy, which focuses on high skills that cannot be found among EEA citizens. Finally, migrants who come to Ireland to pursue higher education might contribute to this phenomenon (Gusciute et al., 2015). 
On average, the migrant population is highly educated and this applies to both EU citizens and third-country nationals. ${ }^{13}$ When it comes to the last group, in Ireland the share of individuals with higher education is significantly higher than within the native population (62 per cent and 38 per cent, respectively) (OECD, 2018a).

\subsubsection{Conclusions}

To sum up, one could argue that Ireland is in a comparatively good position, as its foreign-born population may be less prone to the integration challenges identified in research in other European countries. In this sense, there are few signs of an 'integration crisis'. The vast majority of foreign-born individuals reside in Ireland with the purpose of work or education. This means that relative to other groups they already are integrated to some extent into important aspects of social and economic life. This, however, does not mean the challenges of integration are completely resolved, nor that foreign-born individuals are not victims of discrimination on various grounds (McGinnity et al., 2018; 2020). There are big differences between two broad groups of migrants. While the vast majority of EU citizens come to Ireland in order to work, non-EU nationals primarily arrive in Ireland for education, though many also come to work (Arnold et al., 2019).

It should be stated that European countries differ to a large extent with respect to their demographic structures and integration indicators. These may present as a 'problem pressure' of poor integration, which States may seek to address in part by stricter access to citizenship (Joppke, 2007). First, in many of them, their migrant population is made up primarily of non-EU nationals. Ireland stands out in this respect as its migrant population is primarily made up of nationals of EU Member States and the UK. Second, a significant difference between Ireland and traditional immigrant EU countries is the reason for stay, both in terms of stocks and flows. Most non-EU immigrants reside in Ireland in order to either study or work. In most other countries, one of the main reasons is family reunification. Third, as a consequence, on average, the immigrant population in Ireland is almost as active in the labour market as the native one and when looking at the numerically dominant EU citizens, their employment levels are significantly higher than Irish citizens. Finally, the Eurobarometer study suggests that Irish society sees the integration of immigrants as a success - the highest such score in the EU. One could argue that such positive picture of Ireland emerging from the international comparison presented above, especially concerning non-EU migrants, can be seen in part as a result of immigration policy (Arnold et al., 2019). Having reviewed the context for citizenship policies, the next chapter reviews language requirements. 


\section{CHAPTER 3}

\section{Language requirements and supports}

\subsection{INTRODUCTION}

Language skills facilitate integration in the labour market, education and society more generally. In many European countries a language proficiency test is a requirement for accessing citizenship. Language requirements in Europe have become increasingly strict with more countries introducing or formalising a requirement in recent years (Bauböck and Goodman, 2012). However, limited research exists on whether language tests are effective in achieving better integration (Strik, 2013; Rocca et al., 2020). Some types of language requirements may act as barriers, particularly for illiterate and poorly educated groups (Strik, 2013).

Most EU Member States have a language requirement in place for citizenship applicants. The majority are aligned to the Common European Framework of Reference for Languages (CEFR). See Table 3.1.

The following section provides a broad overview of language requirements in place in the EU plus the UK that are specifically related to citizenship acquisition, and related supports available. The discussion is based on the findings of a mapping exercise, which drew on information mainly from government websites, templates submitted for the EMN study on Pathways to Citizenship, GLOBALCIT publications and other publications where available. Information was gathered on which countries have language requirements in place for citizenship applicants; how that requirement may be met, including the method of assessment, if any; which languages are required; and what level of competence is foreseen. Where possible, information was gathered on costs to the applicants and the type of supports, if any, offered by the State.

\subsection{COMMON EUROPEAN FRAMEWORK OF REFERENCE FOR LANGUAGES}

The CEFR was developed by the Council of Europe to provide a transparent basis for the assessment of foreign language proficiency, among other objectives. ${ }^{14}$ It supports the Council of Europe position that knowledge of a host country's language facilitates migrant integration. However, it has been noted that the Framework was not designed as an instrument for measuring integration 
(Strik, 2013). The Linguistic Integration of Adult Migrants (LIAM) project was established in 2006, to help strengthen policy and practice on language teaching and learning that recognises migrants' human rights (Beacco et al., 2017).

TABLE 3.1 COMMON EUROPEAN FRAMEWORK OF REFERENCE FOR LANGUAGES (CEFR): GLOBAL SCALE: COMMON REFERENCE LEVELS, ABRIDGED

\begin{tabular}{|c|c|c|}
\hline \multirow{2}{*}{$\begin{array}{l}\text { Proficient } \\
\text { user }\end{array}$} & $\mathrm{C} 2$ & $\begin{array}{l}\text { Can understand with ease virtually everything heard or read. Can express him/herself } \\
\text { spontaneously, fluently and differentiating finer shades of meaning. }\end{array}$ \\
\hline & $\mathrm{C} 1$ & $\begin{array}{l}\text { Can express him/herself fluently and spontaneously, using language flexibly for social, } \\
\text { academic and professional purposes. Can understand and produce detailed text on } \\
\text { complex subjects. }\end{array}$ \\
\hline \multirow{2}{*}{$\begin{array}{l}\text { Independent } \\
\text { user }\end{array}$} & B2 & $\begin{array}{l}\text { Can understand the main ideas of complex text on both concrete and abstract topics, } \\
\text { including technical discussions in his/her field of specialisation. Can interact with a } \\
\text { degree of fluency and spontaneity. Can produce clear, detailed text on a wide range } \\
\text { of subjects and explain a viewpoint on a topical issue. }\end{array}$ \\
\hline & B1 & $\begin{array}{l}\text { Can understand the main points of clear standard input on familiar matters regularly } \\
\text { encountered in work, leisure, etc. Can deal with most situations likely to arise. Can } \\
\text { produce simple connected text on familiar topics. Can describe experiences and events } \\
\text { and briefly give explanations for opinions and plans. }\end{array}$ \\
\hline \multirow{2}{*}{ Basic user } & $\mathrm{A} 2$ & $\begin{array}{l}\text { Can understand sentences and frequently used expressions related to areas of most } \\
\text { immediate relevance (e.g. very basic personal information, shopping, local geography, } \\
\text { employment). Can communicate in simple and routine tasks. Can describe in simple } \\
\text { terms in areas of immediate need. }\end{array}$ \\
\hline & A1 & $\begin{array}{l}\text { Can understand and use familiar everyday expressions and very basic phrases. Can } \\
\text { introduce him/herself and others and can ask and answer questions about personal } \\
\text { details. Can interact in a simple way provided the other person talks slowly and clearly } \\
\text { and is prepared to help. }\end{array}$ \\
\hline
\end{tabular}

Source: Council of Europe, www.coe.int/en/web/common-european-framework-reference-languages/table-1-cefr-3.3-commonreference-levels-global-scale.

\subsection{OVERVIEW OF LANGUAGE REQUIREMENTS FOR CITIZENSHIP APPLICANTS IN EU MEMBER STATES}

Within the EU, 24 Member States ${ }^{15}$ plus the UK have a language requirement in law for citizenship applicants and three do not: Ireland, Cyprus, and Sweden. In Cyprus although a formal language requirement does not exist, language competence at the naturalisation interview may feature in final decision-making (Charalambidou, 2013). In Sweden, a previous language requirement ceased to be applied in the early 1980s, but its reintroduction is currently under consideration (European Migration Network, 2020). While the majority of EU Member States have a language requirement in place in law, there is considerable diversity in how it is applied. National practices vary from a simple declaration made by the applicant, as is in the case in Malta, to structured tests specifically designed for

15 Austria, Belgium, Bulgaria, Croatia, Czech Republic, Denmark, Estonia, Finland, France, Germany, Greece, Hungary, Italy, Latvia, Lithuania, Luxembourg, Malta, Netherlands, Poland, Portugal, Romania, Slovakia, Slovenia, Spain, United Kingdom. 
citizenship applicants as in Latvia and Lithuania. Although there is no specific language test in Hungary, language skills are required to pass the citizenship test and interview (EMN Hungary, 2019). Table 3.2 provides an overview of language requirements and related supports in EU Member States plus the UK. 
TABLE 3.2 OVERVIEW OF LANGUAGE REQUIREMENTS AND RELATED SUPPORTS IN EU MEMBER STATES PLUS THE UK

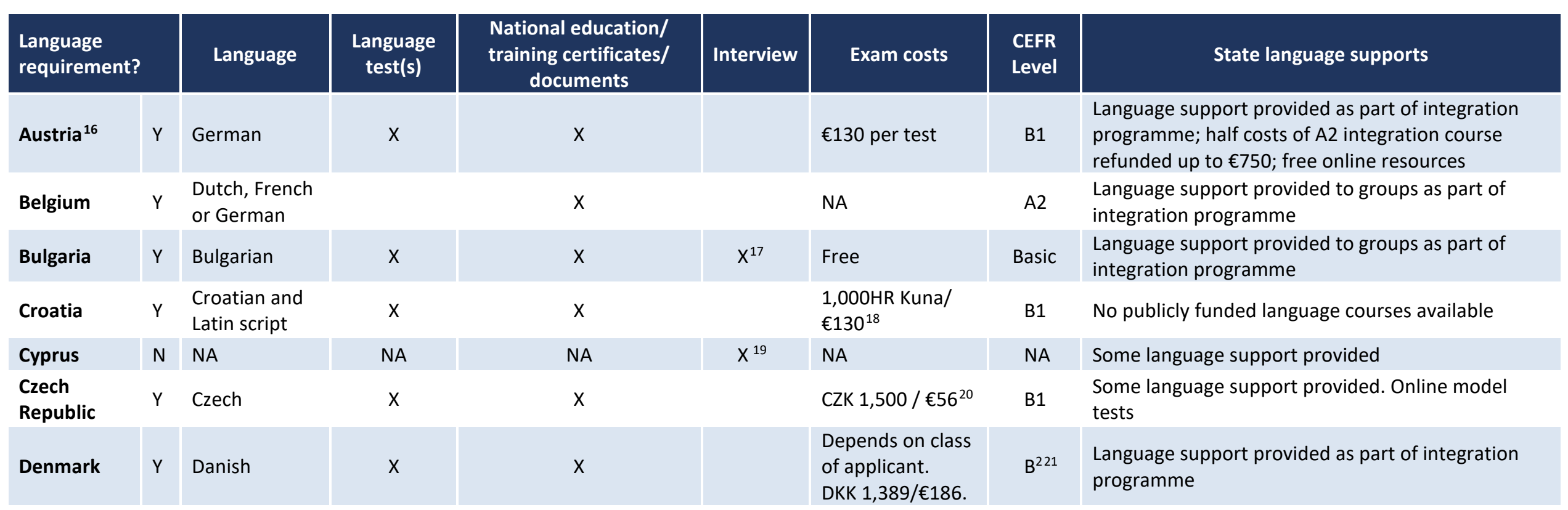

Prove by fulfilling Module 2 of the Integration Agreement by exam or by exception.

An interview in the national language is part of the overall process.

Sajfert, 2013.

An interview in the national language is part of the overall process.

The first attempt at taking the exam is paid for by the State.

1 Rocca et al., 2020 


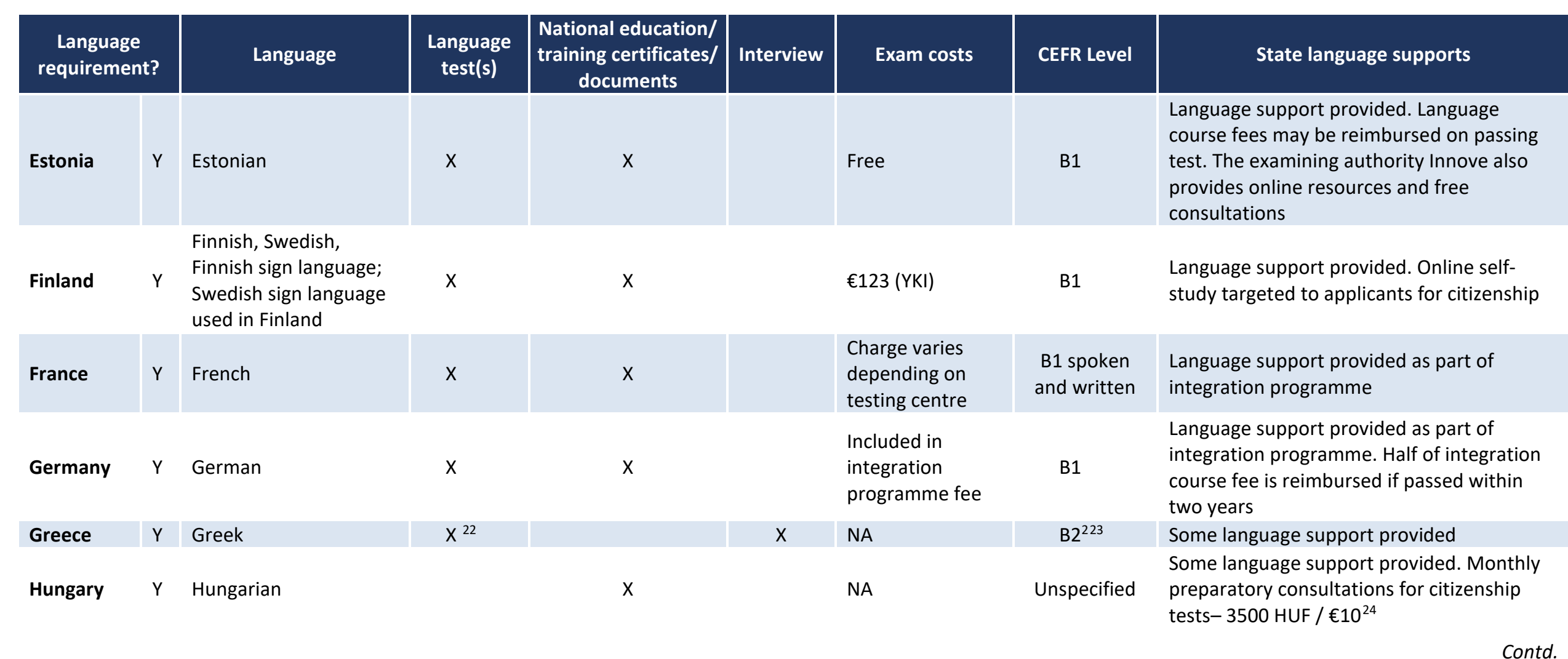

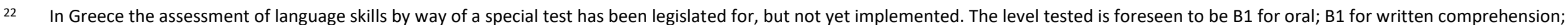
A1 for written (EMN Greece, 2019).

23 Rocca et al., 2020.

24 Pogonyi, 2013. 


\begin{tabular}{|c|c|c|c|c|c|c|c|c|}
\hline \multicolumn{2}{|c|}{$\begin{array}{l}\text { Language } \\
\text { requirement? }\end{array}$} & Language & $\begin{array}{l}\text { Language } \\
\text { test(s) }\end{array}$ & $\begin{array}{l}\text { National education/ } \\
\text { training certificates/ } \\
\text { documents }\end{array}$ & Interview & Exam costs & CEFR Level & State language supports \\
\hline Ireland & $\mathrm{N}$ & NA & NA & NA & NA & NA & NA & Some language support provided \\
\hline Italy & $\mathrm{Y}$ & Italian & $x$ & $x$ & & No information & B1 & Some language support provided \\
\hline Latvia & $\mathrm{Y}$ & Latvian & $x$ & $x^{25}$ & & No information & B1 & $\begin{array}{l}\text { Some language support provided. } \\
\text { Information days with sample tests }\end{array}$ \\
\hline Lithuania & $\mathrm{Y}$ & Lithuanian & $x$ & $x$ & & $<€ 3^{26}$ & $\mathrm{~A} 2$ & $\begin{array}{l}\text { Some language support provided. } \\
\text { Downloadable manual }{ }^{27}\end{array}$ \\
\hline Luxembourg & Y & Luxembourgish & $x$ & & & $\begin{array}{l}€ 75 \text { - may be } \\
\text { reimbursed }\end{array}$ & $\begin{array}{l}\text { A2 (speaking); } \\
\text { B1 (listening) }\end{array}$ & $\begin{array}{l}\text { Language support provided as part of } \\
\text { integration programme. Courses fees may } \\
\text { be reimbursed up to } € 750\end{array}$ \\
\hline Malta & $\mathrm{Y}$ & $\begin{array}{l}\text { Maltese, } \\
\text { English }\end{array}$ & & $\mathrm{x}$ & Declaration & NA & Not specified & Some language support provided \\
\hline Netherlands & Y & Dutch & $x$ & $\mathrm{x}$ & & $\begin{array}{l}€ 290 \text {, Inburgeren } \\
\text { (Integration) exam - } \\
€ 180, \text { Nt2 exam }\end{array}$ & $\mathrm{A} 2$ & $\begin{array}{l}\text { Language support provided as part of } \\
\text { integration programme but all costs paid } \\
\text { by applicant. DUO offers loans towards } \\
\text { financing courses and exam }\end{array}$ \\
\hline Poland & $\mathrm{Y}$ & Polish & $\mathrm{x}$ & $x$ & & $\begin{array}{l}\text { Maximum } € 150 \text { plus } \\
€ 20 \text { for issuing a } \\
\text { certificate }\end{array}$ & B1 & $\begin{array}{l}\text { Language support provided as part of } \\
\text { integration programme }\end{array}$ \\
\hline Portugal & Y & Portuguese & $x$ & & & NA & $\mathrm{A} 2$ & $\begin{array}{l}\text { Language support provided. Free } \\
\text { Portuguese for All (PPT) Programme }\end{array}$ \\
\hline Romania & $\mathrm{Y}$ & Romanian & & & $x$ & NA & Not specified & $\begin{array}{l}\text { Language support provided as part of } \\
\text { integration programme }\end{array}$ \\
\hline
\end{tabular}

25 Persons who have undertaken specified levels of education in Latvia are exempt.

26 Ruškyte (2013).

$27 \quad$ lbid. 


\begin{tabular}{|c|c|c|c|c|c|c|c|c|}
\hline \multicolumn{2}{|c|}{$\begin{array}{l}\text { Language } \\
\text { requirement? }\end{array}$} & Language & $\begin{array}{l}\text { Language } \\
\text { test(s) }\end{array}$ & $\begin{array}{l}\text { National education/ } \\
\text { training certificates/ } \\
\text { documents }\end{array}$ & Interview & Exam costs & $\begin{array}{l}\text { CEFR } \\
\text { Level }\end{array}$ & State language supports \\
\hline Slovak Rep. & Y & Slovakian & $x$ & & $x$ & No information & $\begin{array}{c}\text { Not } \\
\text { specified }\end{array}$ & $\begin{array}{l}\text { No publicly funded language } \\
\text { courses available for adults }\end{array}$ \\
\hline Slovenia & Y & Slovenian & $x$ & $x$ & & $\begin{array}{l}\text { Free if attended } 80 \% \text { of } \\
\text { language course. } € 23 \text { for } \\
\text { certificate }\end{array}$ & $\mathrm{A} 2$ & $\begin{array}{l}\text { Language support provided as } \\
\text { part of integration } \\
\text { programme }\end{array}$ \\
\hline Spain & Y & Spanish & $x$ & & & $\begin{array}{l}\text { Approx. } € 130 \text { for DELE } \\
\text { depending on the } \\
\text { examination centre }\end{array}$ & $\mathrm{A} 2$ & No information \\
\hline Sweden & $\mathrm{N}$ & NA & NA & NA & NA & NA & NA & $\begin{array}{l}\text { Language support provided as } \\
\text { part of integration } \\
\text { programme }\end{array}$ \\
\hline $\begin{array}{l}\text { United } \\
\text { Kingdom }\end{array}$ & Y & $\begin{array}{l}\text { English, Welsh, } \\
\text { Scottish Gaelic }\end{array}$ & $x$ & $x$ & & NA & B1 & $\begin{array}{l}\text { Some language support } \\
\text { provided }\end{array}$ \\
\hline
\end{tabular}

Source: Unless stated otherwise source is EMN (2020) EMN National reports or official government websites. Information on state supports is drawn from FRA, 2017 and official government websites. 


\subsection{LANGUAGE TESTS}

\subsubsection{Types of test}

Table 3.2 shows that in most Member States applicants may take a test to demonstrate language skills for the acquisition of citizenship. In the case of Estonia, Croatia, Luxembourg, Latvia, Lithuania and the Slovak Republic, a targeted test caters for citizenship applicants (European Migration Network, 2020). In Luxembourg for example, applicants must prove knowledge of Luxembourgish by holding a language certificate issued by the National Institute of Languages, which is under the auspices of the Ministry of Education, Children and Youth. In the Czech Republic one test targets all potential permanent residents. ${ }^{28}$ However, most tests have broader target groups, for example in Finland where the main test for naturalisation applicants is also targeted at people seeking a job or language bonus at work. ${ }^{29}$

There may also be several tests available to citizenship applicants. In Portugal and Finland two language tests are approved for naturalisation applicants (CAPLE and IAVE in Portugal; YKI and the civil service language test in Finland) (see Chapter 5). In France the main test targeted at naturalisation applicants is the TCF ANF, but other options are possible. ${ }^{30}$ Similarly in Germany while the Integration course leads to the DTZ test, a number of other ALTE ${ }^{31}$-approved tests are permissible. ${ }^{32}$

In reference to the DELE test used in Spain, Bruzos et al. (2018) highlight that using a pre-existing language test with a broad target group as a means of also meeting citizenship requirements, can raise concerns about the validity of the test because its purpose is too vague. ${ }^{33}$

Rocca et al. (2020) noted that civics tests can also act as a form of language test, for which the required proficiency level is unspecified, and may in some cases exceed the level required in those countries which also include a language requirement. In Hungary the completion of a test on knowledge of history, geography, law, culture and literature in Hungarian is the way in which language is tested (EMN Hungary, 2019). Pogonyi (2013) comments that these successful

'TCF pour l'accès à la nationalité Française (ANF)'. Available at www.ciep.fr/tcf-anf. Accessed March 2020.

Association of Language Testers in Europe. See Section 3.4.3.

'The content and stages of the procedure' Available at www.bamf.de. Accessed March 2020.

The DELE was created in 1988 and amended in 1992 as part of an effort to standardise the teaching of Spanish as a foreign language. Bruzos et al. (2018).

'National certificates of language proficiency (YKI): Frequently asked questions'. Available at www.oph.fi/en. Accessed 
applicants therefore require language skills at an advanced level, suggested by Tóth (2010) to reach C1 level.

\subsubsection{Integration courses and requirements}

The language test required for naturalisation intersects with a broader integration requirement in several Member States. In Austria applicants for long-term residence and citizenship are required to prove their language skills by fulfilling Module 2 of the Integration Agreement. Module 2 is intended to provide German language skills and to obtain advanced knowledge of the fundamental values of the legal and social systems. This module may be deemed completed if the applicant completes the integration exam ('Integrationsprüfung B1'), which tests language skills at B1 level as well as knowledge of values and orientation content. ${ }^{34}$

In the Netherlands a third-country national must pass the integration exam and obtain the diploma (or have been exempted) in order to naturalise. The integration exam consists of several different components, one of which is the language exam. The responsible authority for the civic integration exam is the Executive Agency for Education (DUO). Most third-country nationals are obliged to pass the civic integration exam within three years of receiving a non-temporary permit. Only people who had no earlier obligation to pass the integration exam have to pass the naturalisation test (EMN Netherlands, forthcoming).

In Germany a language test is not directly linked to the naturalisation process, but an applicant must show competence in German at B1 level in order to naturalise. Participants in an integration course may take the 'German language test for immigrants' (DTZ) and the 'Life in Germany' test at the end of the course. ${ }^{35}$ The DTZ is at B1 level and satisfies the naturalisation requirement. Participation in an integration course is mandatory for migrants with poor language skills and unemployed persons may also be required to attend. The immigration authority determines if a person must participate when it issues a residence permit. ${ }^{36}$

Successful attendance at an integration course in Germany also reduces the required residence period for naturalisation from eight to seven years (Farahat and Hailbronner, 2020), reduced further to six years for people with B2 language skills (EMN Germany, 2018). In Finland too, the value placed on language skills is reflected in the fact that the required residence period for naturalisation is reduced 
by one year if an applicant meets the language skills requirement, has strong ties with Finland and has their primary place of residence in Finland (see Chapter 5).

In Belgium, while it is possible to demonstrate compliance with the language requirement by taking a test and submitting the relevant certificate, many more options are available as discussed in Chapter 5. In all three communities and the Brussel-Capital region, the integration course offered includes training at A2 level, which will meet the language requirement.

In Italy, as of December 2018, applicants for naturalisation must prove that they have reached B1 level in Italian. The requirement does not apply to applicants who have fulfilled an integration agreement or to those who have gained permanent residence and have shown their language skills in other ways. There are two main ways for applicants to prove language skills: with a language certificate from a school/centre approved by the Ministry of Education/Ministry of Foreign Affairs or with a school qualification. ${ }^{37}$

\subsubsection{Design and organisation of tests}

The Association of Language Testers in Europe (ALTE) ${ }^{38}$ has produced a booklet to support decision-makers where mandatory testing is in place, or under consideration for migration purposes. Decision-makers are urged to reflect on the impact of using tests, both on individual migrants and on wider society, any unintended consequences that could arise (e.g. segregation of particular groups), groups that may be discriminated against and whether another form of assessment might be more appropriate. It is argued that a needs analysis is essential, in order to collect information about migrants' geographical, language and skills backgrounds and the linguistic demands they are likely to encounter, as well as the needs of stakeholders such as employers, educators and the wider public (Council of Europe, 2016).

The authors stress that test fairness is particularly important when tests are used for migration purposes, as unfair tests may result in migrants being denied civil or human rights. Ensuring fairness begins in the planning stages and continues throughout the operation of the test. The purpose of the test must be explicit - to test takers and to other members of society who will interpret and use test results. The booklet recommended that the test is continually monitored to ensure quality,

37 'Language'. Available at: www.integrazionemigranti.gov.it. Accessed June 2020.

38 ALTE is a multilingual organisation that has the status of an International Non-Governmental Organisation, (INGO) with Participatory Status in the Council of Europe. The activities of ALTE include helping members to develop the quality of their tests and auditing the tests of its members. See www.alte.org. 
and quality assurance procedures, such as the ALTE Q-mark, should be in place (Council of Europe, 2016).

In a 2018 survey of Council of Europe member states/regions, eight of 33 respondents which have language proficiency or knowledge of society requirements related to migration (i.e. as a precondition to entry, residency or citizenship) in place, ${ }^{39}$ indicated that the requirements are based on research, in most cases in the form of consultation with language professionals rather than empirical research. The survey found that around half of states/regions used standardised measurement instruments. The quality of the test instrument was checked in 12 member states, but just seven tests used for migration purposes had an ALTE Q-mark (Rocca et al., 2020).

In the EMN study Pathways to Citizenship, National Contact Points (NCPs) were asked about evaluation of citizenship language tests specifically. Several National Contact Points reported that the main tests relevant to naturalisation applicants are associated with ALTE and as such undergo quality audits: Austria, ${ }^{40}$ Czech Republic, Estonia, Finland, Slovenia, Spain. The Latvian test was audited by ALTE in 2007. Several NCPs reported that no evaluations have taken place (Belgium, Estonia, France, Croatia, Greece and Hungary) while Bulgaria reported an internal review. The University of Luxembourg conducts periodic psychometric analyses of the language test and, based on these analyses, some elements are either modified or removed. This type of review does not evaluate if the test led to better knowledge of the Luxembourgish language (EMN Luxembourg, 2019).

In Germany an evaluation committee evaluates and develops the structure and content of integration courses, including test content. The committee comprises representatives of the federal government, the federal states, local authorities, academia and practice (Schuller et al., 2011).

Member states adopt a variety of approaches to appointing organisations to design and administer the language test. The Council of Europe $(2013 ; 2016)$ stresses that close cooperation is needed between policymakers - who take the decision to implement a language test for citizenship - and test providers, including on defining the precise purpose of the test, the appropriate allocation of resources and test fairness. In Latvia, the immigration service administers the test and in participate), in addition to Albania, Andorra, Armenia, Iceland, Monaco, North Macedonia, Norway, Moldova, Russia, San Marino, Switzerland, Turkey and the UK. In the survey, the Flanders and Walloon region of Belgium were considered as two distinct regions. 
Austria the State Austrian Integration Fund (ÖIF) develops and runs tests, some of which may also be taken at institutes certified by ÖIF. ${ }^{41}$ Often agencies under the auspices of the Education ministry are responsible for the test, such as the Finnish National Agency for Education and the National Institute of Languages ('Institut National des Langues' - INLL), which operates under the Luxembourgish Ministry of Education, Children and Youth.

Several member states, for example Portugal, France, Spain as well as the UK use external service providers to develop and to implement the test. In Portugal the two main tests are operated by CAPLE (Centre for Evaluation of Portuguese as a Foreign Language), which is developed and accredited with the University of Lisbon, and IAVE (Institute for Educational Assessment). These approved tests may be used locally by other organisations. In the UK, providers must be listed on the Secure English Language Test List and currently just two test providers are approved: Trinity College London and IELTS SELT Consortium. ${ }^{42}$ In Spain the Cervantes Institute designs and administers the tests. Test providers may be restricted to prevent fraud, and to ensure quality standards are met. In contrast Croatia has moved to broaden the range of test operators from a limited number of universities, to include vocational training institutions and high schools (Sajfert, 2013).

Almost all member states seek competence in the four components of listening, speaking, reading and writing except for Luxembourg where only speaking and listening is tested. In France the requirement for B1 oral language skills was introduced in 2011. At the end of 2019 the requirement was raised to B1 oral and written, effective from April 2020 (EMN France, 2019). In Germany and Slovenia the written test lasts approximately 100 minutes which includes listening and reading exercises, as well as an oral test lasting approximately 15 minutes. ${ }^{43}$ Portugal and France follow a similar format.

If the language test must be passed prior to applying for naturalisation (as in Austria, Finland and the UK), failure can delay or prevent an application being made. If an applicant fails, a repeat exam is usually possible, but time limits often apply. For example, in Estonia a candidate who scores less than 35 per cent may

41 'German tests'. Available at: www.integrationsfonds.at/en/news/detail?tx_news_pi1\%5Baction\%5D=detail\&tx_news_pi1\%5Bcontroller\%5D=New s\&tx_news_pi1\%5Bnews\%5D=3084\&cHash=01bf9bcc4bb4ccb2adc6daca4bf4e660. Accessed March 2020.

42 'Approved Secure English Language Tests'. Available at: https://assets.publishing.service.gov.uk/government/uploads/system/uploads/attachment_data/file/834327/201910-01_-_Approved_secure_English_language_tests.pdf. Accessed March 2020.

43 'The final examination and the certificate'. Available at: www.bamf.de/EN/Themen/Integration/ZugewanderteTeilnehmende/Integrationskurse/Abschlusspruefung/abschlus spruefung-node.html ; https://centerslo.si/en/exams/slovene-language-\%20exams/the-basic-level-\%20exam. Accessed March 2020. 
not re-sit for six months. In Latvia and Slovenia the language test is part of the naturalisation application. In Latvia an applicant may resit after three months, up to three times, after which the application for naturalisation is rejected. In both Latvia and Slovenia candidates may repeat only failed component(s). The frequency of exam scheduling can elongate the process in some countries, ranging from a few days (e.g. in UK) to months (e.g. in Portugal and Finland). In Denmark the tests are held just twice per year. Detailed feedback is generally not provided, however in Slovenia candidates may discuss their examination paper with 'expert staff'. Appeals of exam results were possible in most states. Strik (2013) stresses that checks should be in place to ensure that failure rates, which can be high, do not have a discriminatory effect and should not lead to the denial of citizenship.

\subsection{HOST-COUNTRY SCHOOL OR UNIVERSITY CERTIFICATES AND OTHER DOCUMENTARY EVIDENCE}

In most Member States ${ }^{44}$ applicants also have the option to supply official language diplomas from a range of educational institutions or proof of work experience in the country (European Migration Network, 2020). In Austria evidence of also having completed German classes must usually be provided (except for primary school-going children). ${ }^{45}$ In Belgium significant flexibility is offered regarding the type of document that may be submitted. These range from certificates issued by educational institutions (the training does not have to be language-related) to evidence that the applicant has worked in Belgium for at least five years. However, legal challenges have arisen where third-country nationals are deemed to have insufficient knowledge of the languages even though they could produce one of the documents required by the law (EMN Belgium, forthcoming).

\subsection{INTERVIEWS AS LANGUAGE ASSESSMENT}

In Greece, applicants are required to attend a personal interview before a Naturalisation Committee, which verifies adequate knowledge of Greek (Christopoulos, 2013). Greece has legislated for the introduction of a targeted test for naturalisation, but it has not yet been implemented (EMN Greece, 2019). In the Slovak Republic, authorities assess the applicant's command of the Slovak language during a test which includes an interview in which the applicant is asked personal questions as well as questions on the country's history, geography and social and political development (European Migration Network, 2020). During the interview the applicant is required to read aloud and later summarise a newspaper 
article. ${ }^{46}$ The naturalisation interview is also the means for assessing language skills in Romania, but Barbulescu (2013) observes that no guidelines are available on what constitutes sufficient knowledge of language (or culture) to pass the interview.

\subsection{LEVEL OF LANGUAGE REQUIRED}

In terms of the level of language skills required from citizenship applicants, seven Member States set the standard at A2 or 'basic user' ${ }^{47}$ on the Common European Framework of References (CEFR). As shown in Table 3.1 this means users should be able to understand and use familiar everyday expressions and very basic phrases aimed at the satisfaction of concrete needs. Some ten Member States plus the UK seek evidence of competence at level B1 'independent user', ${ }^{48}$ meaning that users should be able to understand the main points of clear standard input on familiar matters, and produce simple connected text on topics which are familiar or of personal interest. A further two Member States - Greece and Denmark - are recorded as setting the standard at $B 2$ which demands an understanding of the main ideas of complex text on concrete and abstract topics, including technical discussions in his/her field of specialisation. (In Greece the introduction the of a language test at level B1/A1 is foreseen.) In addition, in Bulgaria the language level is set at 'elementary/basic', while in Hungary, Malta, Romania and the Slovak Republic no language level is specified. Only in Luxembourg are different levels set for speaking (A2) and listening (B1).

The Council of Europe detects an increase in the level of language required by its member countries: Rocca et al. (2020) found that while one Council of Europe country had a B2 requirement for citizenship in 2007, this had increased to four countries in 2018. Strik (2013) recommends that language levels are set at levels that are reasonably attainable: level A2 for speaking and listening and the basic level of $A 1$ for writing and reading. Learners with limited literacy and low levels of schooling may never achieve higher than A1, regardless of how many hours are spent (Rocca et al., 2020). The lack of consistency across countries as to the level of proficiency required is also highlighted. Böcker and Strik (2011) argue that these differences throw doubt on the argument that immigrants need the proficiency level they are required to demonstrate, in order to successfully integrate.

\subsection{SUPPORTS FOR LANGUAGE LEARNING}

Bauböck et al. (2013) emphasise the need for any language requirements linked to naturalisation to reflect the level of state language support provided. 
A comprehensive overview of language supports available in each Member State was beyond the scope of this research. FRA (2017) found that all EU Member States provided some form of funding for language-learning programmes, other than Croatia and Slovakia; in the latter case supports are available for children only. No data were available for Spain. Rocca et al. (2020) found that of 36 responding Council of Europe states, half provided language courses free of charge for all migrants, while one-third provided free courses for certain groups of migrants. The particular focus in this section is on language supports designed to help participants meet the requirements for citizenship, and Table 3.2 includes available information on the diverse approaches taken across the Member States.

In Austria, Belgium, Bulgaria, Germany, Denmark, France, Luxembourg, Poland, Romania, Slovenia and Sweden, language support is provided as part of special integration programmes (FRA, 2017). In Germany the standard integration course of 700 hours costs $€ 1,365$, but costs may be waived for recipients of unemployment benefit or social assistance. If the DTZ test is passed within two years, half of the costs may be refunded. ${ }^{49}$ In Austria applicants may apply for partial reimbursement of integration course costs on successful completion of a language exam up to A2 integration test from the ÖIF. ${ }^{50}$ Partial reimbursement of language course costs is also possible in Estonia and Luxembourg.

In Belgium, one of several options for proving language skills is the completion of an integration course, while in France and Finland language courses offered in the context of an integration plan can help to meet the requirement. In Denmark as part of general integration measures, free language classes are provided depending on the status of the individual. Subject to the payment of a refundable deposit, 'self-supporting' persons may access free language classes for 4-5 years. These are compulsory for refugees and people receiving unemployment benefit (Council of Europe, 2016).

In Portugal free language tuition is offered to immigrants under the Portuguese for All programme (PPT) which targets prospective applicants who want to achieve permanent residence or citizenship by naturalisation. It receives co-financing from the European Social Fund and is operated by High Commission for Migration (ACM) (see Chapter 5).

49 'Foreign nationals with residence titles issued from 2005 onwards'. Available at: www.bamf.de/DE/Themen/Integration/ZugewanderteTeilnehmende/Integrationskurse/TeilnahmeKosten/Titelab200 5/titelab2005.html. Accessed March 2020.

50 'Information for migrants'. Available at: www.integrationsfonds.at/sprache/integrationsvereinbarung/integrationsvereinbarung-2017-und-intg-dv/infos-fuermigrant/innen. Accessed March 2020. 
In the Netherlands, integration courses - including language courses - and exams must be paid for by the applicant. DUO offers loans towards financing courses for approved schools, the NT2 exam and Inburgering (Integration) exam. Some childcare costs may be reimbursed to allow parents to attend classes. ${ }^{51}$

Many Member States provide online resources including manuals, tutorials and practice exams, for example Austria, Estonia, Finland, France and Lithuania. In Latvia information days are held, with access provided to sample tests.

The Council of Europe (2013) stressed the importance of providing adequate financial support for preparatory courses linked to language tests, arguing that when migrants are required to pay for courses, this can act as a major barrier. Rocca et al. (2020) argues that in most Council of Europe countries low-literate language learners rarely receive more hours to compensate for their learning pace.

\subsection{MULTIPLE LANGUAGES}

In three Member States the language requirement may be met in multiple languages: Belgium (Dutch, French and German), Finland (Finnish and Swedish, Finnish sign language and Swedish sign language used in Finland) and Malta (Maltese and English). Finland was the only country identified as allowing for sign language testing (Council of Europe, 2016), thus facilitating the integration of groups who may not have access to general language/integration programmes. In Luxembourg, from 2001, applicants were required to have knowledge of one of the three official languages: French, German and Luxembourgish, and demonstrate basic knowledge of Luxembourgish. A test was subsequently introduced in 2009 following revised requirements that applicants should prove sufficient knowledge of Luxembourgish only.

In the UK applicants must have sufficient knowledge of English, Welsh or Scottish Gaelic. However in official guidance, mention is predominantly made of satisfying English language requirements, with no reference to Welsh and only limited reference to Scottish qualifications (see Chapter 5).

In Luxembourg, although French and German are official languages, Luxembourgish is the only language tested for at naturalisation. Luxembourgish is predominantly used as a means of oral rather than written communication by nationals (Horner, 2017). Applicants' knowledge of Luxembourgish must be evidenced by the Luxembourgish language test, which covers oral and hearing comprehension only (EMN Luxembourg, 2019). In reference to Spain, Bruzos et al. 
(2018) argue that establishing a requirement for new citizens risks reinforcing the subordination of other co-official languages such as Galician, Basque and Catalan (Bruzos et al., 2018).

\subsection{SPECIAL REQUIREMENTS AND EXEMPTIONS}

The Council of Europe (2016) stresses the importance of fairness in testing for migration purposes, to avoid civil or human rights being impacted. A contrast is drawn between language tests taken for study and work where, in most cases, candidates are relatively homogeneous in terms of educational background and cognitive skills. Tests for migration purposes must cater for a wide range of possible candidates. They must also take account of the special needs and abilities of vulnerable persons and groups with other difficulties, such as the elderly and refugees. Low literacy groups must be supported to achieve literacy, before any writing or reading tests can be undertaken. As Rocca et al. (2020) point out, decision-makers should be aware that learners with limited literacy and low levels of schooling may never achieve higher than A1.

A testing system must take account of physical, mental or emotional impairments or disabilities, learning disorders, dyslexia, regulations related to religion, etc. that could make it more difficult for a candidate to take the test. States must also decide whether any candidates with special requirements will be exempt and which special conditions apply in any given case (e.g. provision of an assistant, extended time, additional rest breaks, sign language interpreter etc.). Information on these regulations and exemptions should be made publicly available and accessible to the candidates. If a decision is made not to provide any special provision, appeal should be facilitated (Council of Europe, 2016).

Rocca et al. (2020) found that vulnerable groups including minors, low-literate learners and refugees are only rarely catered for on language or knowledge of society courses and few Council of Europe states provide systematic exemptions from language or civics requirements for vulnerable groups. Furthermore, the research found that low-literate learners were not generally provided with sufficient hours of instruction to reach the language level that was required.

European Migration Network (2020) found that 13 Member States permitted exemptions from language requirements for people with severe health 
impairments and/or disabilities, ${ }^{52}$ while ten states exempted older people ${ }^{53}$ usually aged 60-65 years and up.

In Luxembourg the law was amended in 2017 to allow for special accommodation to be made for the needs of persons with intellectual or physical disabilities. A request for special conditions may be submitted to the Director of the 'Institut National des Langues' (INL), who may take advice from a Reasonable Accommodation Commission. Possibilities foreseen include separate room for testing, increased rest breaks, technological aids etc. A request for full exemption from the language and civics requirement may be submitted to the Minister for Justice, together with medical certificates. ${ }^{54}$

In the Netherlands applicants who can show that they have tried and failed to pass the integration exam multiple times may make a case for exemption. ${ }^{55}$ Requirements may be reduced for applicants who make a 'special contribution' to the State, for example in the Slovak Republic.

Portugal, Denmark, the United Kingdom and Spain have exemptions/concessions in place for applicants originating from countries where the language of the country of application is spoken. For example, applicants from Australia, Englishspeaking Canada and the US are not required to prove English language skills to obtain UK citizenship. In Denmark, applicants from the Faroe Islands or Greenland have a reduced language requirement, while Swedish or Norwegian speaking applicants must show only a passing examination from a Swedish or Norwegianlanguage elementary school. ${ }^{56}$

\subsection{EVALUATIONS OF CITIZENSHIP LANGUAGE REQUIREMENTS}

Evaluations of the decision to introduce language requirements attached to naturalisation were not found. This may be related to the fact that in several countries, for example Finland, UK and Portugal, the decision to introduce a language requirement for citizenship was taken long ago, in the early decades of the 20 Century, and the relevant policy changes have served to formalise this preexisting position. ${ }^{57}$ Rocca et al. (2020) argue that high-quality language assessments can support migrants if they are used to encourage and guide,

52 Austria, Belgium, Czech Republic, Estonia, Germany, Latvia, Lithuania, Luxembourg, Spain, Netherlands, Portugal, Spain, UK.

53 Belgium, Czech Republic, Germany, Estonia, Croatia, Lithuania, Latvia, Portugal, Spain, UK.

54 EMN ad hoc query number 2020.38 (forthcoming).

55 'Integration in the Netherlands'. Available at www.inburgeren.nl/en/integration-in-the-netherlands/naturalisation.jsp. Accessed March 2020.

56 'Danish Knowledge'. Available at https://uim.dk/arbejdsomrader/statsborgerskab/udenlandskestatsborgere/betingelser/danskkundskaber. Accessed March 2020.

57 See Section 5 for more information. 
according to real life needs and different abilities. However, if they are used to measure integration or capacity to integrate, this logic is largely unsupported by research. Strik et al. (2010) finds that it remains doubtful whether naturalisation tests lead to better integration in society in most of the nine countries examined, with migrant respondents less likely to feel the test contributed to their integration than, for example, language teachers.

The German integration course was evaluated in 2011. A self-assessment instrument ${ }^{58}$ was used to compare the language skills of integration course participants to a control group of new migrants. The research found that course attendees improved more than people who did not attend an integration course. Some 93 per cent of participants saw their German language proficiency improve during the integration course; 51 per cent improved their language skills during the year after the end of the course (with some attending further language education), while 7 per cent kept them at the same level. The research concludes that language skills of certain groups improve particularly well as a result of participating in the integration course; those who don't live in a German-speaking environment, who have lower education, long-term residents and those who have come to Germany as refugees or through family reunification (Schuller et al., 2011). The Netherlands published an evaluation of the Civic Integration Act in 2020, which is available only in Dutch. ${ }^{59}$ However, these types of analyses do not allow us to evaluate the precise relationship between language tests/requirements and language proficiency.

\subsection{CONCLUSIONS}

Language requirements for citizenship in Europe have become increasingly strict with more countries introducing or formalising a requirement in recent years. Within the EU, 24 Member States plus the UK have such a language requirement, while Ireland, Cyprus, and Sweden do not. There is considerable diversity in how the requirement is applied. In most Member States applicants may take a test. In some cases, a targeted test exists for citizenship applicants, but in most countries tests have broader target groups. Language tests for migration purposes are complex to design and implement, partly due to the significant heterogeneity among candidates in terms of demographics, literacy, education and skills background. Also, the stakes are high, as unfair tests could result in migrants being denied civil or human rights. However, a Council of Europe survey in 2018 found that only around half of the 33 member countries/regions with requirements in place used standardised measurement instruments. The quality of the test

58 Developed by the project 'Milestone' as part of the European Language Portfolio (ELP), which is certified by the Council of Europe.

59 Available in Dutch only at www.cpb.nl/sites/default/files/omnidownload/CPB-Notitie-feb2020-Een-nieuwe-kijk-op-deWet-Inburgering-2013.pdf. Accessed March June 2020. 
instrument was checked in 12 member countries, but just seven tests had an ALTE Q-mark. In addition, it was found that vulnerable groups including minors, lowliterate learners and refugees are only rarely catered for on language or knowledge of society courses, while few member countries provide systematic exemptions for vulnerable groups. Almost all EU Member States seek competence in the four components of listening, speaking, reading and writing except for Luxembourg where only speaking and listening is tested.

In most EU Member States, aside from tests, applicants also have the option to supply official language diplomas from a range of educational institutions or proof of work experience in the country (European Migration Network, 2020). Interviews are also used to assess language skills in five EU Member States, sometimes as part of the overall naturalisation application procedure. In terms of the level of language skills required from citizenship applicants, seven Member States set the standard at A2 or 'basic user' on the CEFR. Some ten Member States plus the UK seek competence at level B1 'independent user', while a further two set the standard at B2. Böcker and Strik (2011) argue that these differences throw doubt on the argument that immigrants need the proficiency level they are required to demonstrate, in order to successfully integrate.

Almost all EU Member States offer some support for language courses for migrants, in many cases course fees and/or exam fees are waived/refunded on successful completion of an integration course/test. Several Member States also provide targeted supports such as online tutorials, exam papers etc., specifically for naturalisation applicants. Limited research exists on whether tests are effective in achieving better integration (Bauböck and Goodman, 2012; Council of Europe 2013; Rocca et al., 2020). Evaluations of the decision to introduce language requirements attached to naturalisation were not found. Rocca et al. (2020) argue that high-quality language assessments can support migrants if they are used to encourage and guide, according to real life needs and different abilities. The German integration course was evaluated in 2011 and it was found that 93 per cent of participants saw their German language proficiency improve during the integration course, while 51 per cent improved their language skills during the year after the end of the course. 


\section{CHAPTER 4}

\section{Civic knowledge/integration requirements and supports}

\subsection{INTRODUCTION}

The EU's Common Principles on Integration state that basic knowledge of the host society's language, history, and institutions is indispensable to integration, and enabling immigrants to acquire such knowledge is essential (Council of the European Union, 2004).

In addition to language tests, many EU Member States and the UK also require citizenship applicants to prove knowledge of the host society. Such knowledge may encompass the country's history, geography, political system, culture and rights as well as in some cases what the State views as the local social norms and values. Referred to interchangeably in the literature as 'integration' or 'knowledge of society' requirements or tests, such measures have gradually become part of the citizenship framework in many EU Member States and the UK. Countries introduce such requirements with the aim of facilitating integration. However, it is not clear whether linking civic requirements to the acquisition of citizenship contributes to migrant integration in practice.

This section provides an overview of civics requirements attached to the citizenship process in EU Member States and the UK. Government websites, templates submitted for the EMN study Pathways to citizenship for third-country nationals in the EU (European Migration Network, 2020) naturalisation, and publications by academics, NGOs and national authorities where available were consulted in gathering information on each country. The section discusses those countries in which a civic knowledge/integration requirement is in place, looking specifically at the format of assessment, the type of knowledge assessed, how the requirements operate, and costs to the applicant in meeting the requirements and supports, such as courses or other learning tools, provided by the State to applicants.

\subsection{OVERVIEW OF CIVIC KNOWLEDGE/INTEGRATION REQUIREMENTS IN EU MEMBER STATES AND THE UK}

Citizenship applicants are required to demonstrate civic knowledge or 'integration' as part of the naturalisation process in $18 \mathrm{EU}$ Member States, ${ }^{60}$ and the UK. 
As summarised in Table 4.1, in 11 EU Member States and the UK, civic knowledge is assessed by way of a formal written exam, while five Member States assess knowledge in the course of an interview with immigration officials. In Belgium and Luxembourg, the civic knowledge/integration requirement may be satisfied by completing an integration course. Nine EU Member States do not have any kind of civic knowledge/integration requirement: Cyprus, Finland, Ireland, Italy, Malta, Poland, Portugal, Slovenia and Sweden.

TABLE 4.1 SUMMARY OF CIVIC KNOWLEDGE/INTEGRATION REQUIREMENTS IN EU MEMBER STATES AND THE UK

\begin{tabular}{|c|c|c|c|c|c|c|}
\hline \multirow{2}{*}{ Country } & \multicolumn{3}{|c|}{ Requirement } & \multirow{2}{*}{$\begin{array}{c}\text { Year } \\
\text { introduced }\end{array}$} & \multirow{2}{*}{ Costs } & \multirow{2}{*}{ State supports } \\
\hline & Exam & Interview & Course & & & \\
\hline Austria & $x$ & & & $2006^{61}$ & - & $\begin{array}{l}\text { Federal exam handbook and sample test } \\
\text { publicly available, some provincial } \\
\text { handbooks publicly available }\end{array}$ \\
\hline Belgium & & & $\mathrm{X}$ & $2013^{62}$ & - & $\begin{array}{l}\text { Course available free of charge to } \\
\text { applicants. }\end{array}$ \\
\hline Bulgaria & & $\mathrm{x}$ & & $1999^{63}$ & - & - \\
\hline Croatia & $X$ & & & $2011^{64}$ & - & Exam questions publicly available \\
\hline $\begin{array}{l}\text { Czech } \\
\text { Republic }\end{array}$ & $\mathrm{x}$ & & & 2014 & $\begin{array}{l}\text { CZK } 1,600 \\
(€ 60)\end{array}$ & $\begin{array}{l}\text { Exam questions and sample test publicly } \\
\text { available }\end{array}$ \\
\hline Cyprus & \multicolumn{6}{|c|}{ No civic knowledge/ integration requirement } \\
\hline Denmark & $\mathrm{X}$ & & & $2007^{65}$ & $\begin{array}{l}\text { DKK } 799 \\
(€ 107)\end{array}$ & Exam handbook publicly available \\
\hline Estonia & $\mathrm{X}$ & & & $1995^{66}$ & - & $\begin{array}{l}\text { Free consultations; exam material and } \\
\text { questions publicly available }\end{array}$ \\
\hline Finland & \multicolumn{6}{|c|}{ No civic knowledge/ integration requirement } \\
\hline France & & $x$ & & $2003^{67}$ & - & Interview handbook publicly available \\
\hline Germany & $x$ & & & $2008^{68}$ & $€ 25$ & $\begin{array}{l}\text { Exam questions and sample test publicly } \\
\text { available }\end{array}$ \\
\hline Greece & & $x$ & & 2001 & - & Handbook publicly available \\
\hline Hungary & $\mathrm{X}$ & & & $1993^{69}$ & $\begin{array}{l}74,500 \\
\text { HUF } \\
(€ 214)\end{array}$ & $\begin{array}{l}\text { Handbook at a cost }(3,500 \text { HUF }(€ 10)) \text {; } \\
\text { free consultations }\end{array}$ \\
\hline Ireland & \multicolumn{6}{|c|}{ No civic knowledge/ integration requirement } \\
\hline Italy & \multicolumn{6}{|c|}{ No civic knowledge/ integration requirement } \\
\hline
\end{tabular}

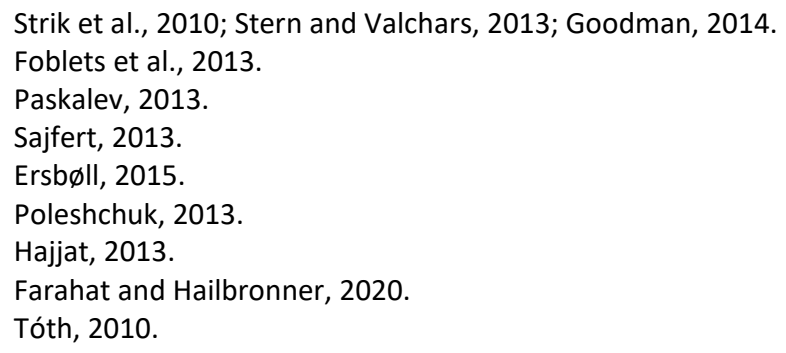




\begin{tabular}{|c|c|c|c|c|c|c|}
\hline \multirow{2}{*}{ Country } & \multicolumn{3}{|c|}{ Requirement } & \multirow{2}{*}{$\begin{array}{l}\text { Year } \\
\text { introduced }\end{array}$} & \multirow{2}{*}{ Costs } & \multirow{2}{*}{ State supports } \\
\hline & Exam & Interview & Course & & & \\
\hline Latvia & $\mathrm{x}$ & & & $1994^{70}$ & - & $\begin{array}{l}\text { Handbook at a cost (€5.14), some test } \\
\text { guidance publicly available; free } \\
\text { information days }\end{array}$ \\
\hline Lithuania & $\mathrm{x}$ & & & $1991^{71}$ & $€ 2.90$ & $\begin{array}{l}\text { List of topics and test guidance publicly } \\
\text { available }\end{array}$ \\
\hline Luxembourg & & & $\mathrm{x}$ & $2009^{72}$ & - & $\begin{array}{l}\text { Course available free of charge to } \\
\text { applicants. }\end{array}$ \\
\hline Malta & \multicolumn{6}{|c|}{ No civic knowledge/ integration requirement } \\
\hline Netherlands & $\mathrm{x}$ & & & $2003^{73}$ & $\begin{array}{l}€ 80 \\
€ 40 \text { per } \\
\text { exam); }\end{array}$ & $\begin{array}{l}\text { Knowledge of Dutch Society handbook } \\
\text { and questions publicly available; } \\
\text { Orientation on the Dutch Labour Market } \\
\text { courses at cost to applicant }\end{array}$ \\
\hline Poland & \multicolumn{6}{|c|}{ No civic knowledge/ integration requirement } \\
\hline Portugal & \multicolumn{6}{|c|}{ No civic knowledge/ integration requirement } \\
\hline Romania & & $x$ & & $1999^{74}$ & - & Questions publicly available \\
\hline Slovakia & & $x$ & & $2007^{75}$ & - & - \\
\hline Slovenia & \multicolumn{6}{|c|}{ No civic knowledge/ integration requirement } \\
\hline Spain & $\mathrm{x}$ & & & 2015 & $€ 85$ & $\begin{array}{l}\text { Exam handbook and sample test publicly } \\
\text { available }\end{array}$ \\
\hline Sweden & \multicolumn{6}{|c|}{ No civic knowledge/ integration requirement } \\
\hline $\begin{array}{l}\text { United } \\
\text { Kingdom }\end{array}$ & $\mathrm{x}$ & & & $2005^{76}$ & $£ 50(€ 56)$ & $\begin{array}{l}\text { Exam handbook at a cost ( } € 12.99 \\
(€ 14.48)) \text {, study guide and questions and } \\
\text { answers at a cost ( } € 7.99 \text { (€8.91) each) }\end{array}$ \\
\hline
\end{tabular}

Source: Unless stated otherwise source is EMN (2020), EMN national reports for the study Pathways to citizenship for third-country nationals in the $E U$ and official government websites.

Notes: Costs are reported only where a cost applies specifically to the exam/interview/course separate to the overall cost for a naturalisation application. Exchange rate calculated in June 2020. The 'year introduced' column reflects the year in which the requirement commenced rather than the year a requirement was established in law or policy. 'Publicly available' means no charge applies.

\subsection{CIVIC KNOWLEDGE EXAM}

In 12 countries, civic knowledge is assessed by way of an exam. ${ }^{77}$ Most exams consist of multiple-choice questions and are paper-based or computer-based written exams, although in Latvia, applicants are given the option of taking either a written or an oral test, ${ }^{78}$ and in Hungary applicants must complete both a written and oral assessment (Pogonyi, 2013).

Krūma, 2013.

Kūris, 2010.

Scuto, 2013.

Van Oers et al., 2013.

Barbulescu, 2013.

Kusá, 2013.

Sawyer and Wray, 2014.

Austria, Croatia, Czech Republic, Denmark, Estonia, Germany, Hungary, Latvia, Lithuania, the Netherlands, Spain and the United Kingdom.

78 Office of Citizenship and Migration Affairs, Ministry of Interior of the Republic of Latvia, 'Examinations provided by the Citizenship Law',

www.pmlp.gov.Iv/en/home/services/citizenship/registration-if-citizenship/naturalizacija/examinations.html. 
The number of questions asked ranges from 15 to 40 questions. In the Netherlands, the civic integration exam consists of two exams: a Knowledge of Dutch Society multiple-choice exam and the Orientation in the Dutch Labour Market (ONA) exam. The Knowledge of Dutch Society exam takes place on the same day as the language exam and consists of watching videos about life in the Netherlands following which the applicant must answer questions. The ONA involves completion of an electronic portfolio showing the applicant is familiar with the labour market and opportunities for work in the Netherlands and either a 64-hour course or a final interview. ${ }^{79}$ Most non-EU nationals are obliged to pass the integration exams within three years of receiving a residence permit in the State.

The topics covered by exam questions typically include knowledge of the country's Constitution, democratic and political system, history, geography, culture and customs. The required knowledge in some instances also covers the national anthem, current affairs and events, access to public goods and services and specific knowledge relating to the region/local area in which the applicant resides. Exams also include questions on social morals and values in some countries. Michalowski (2011) argues that in the context of current debates on Islam in Europe, exam questions in Austria, Germany, the Netherlands and the UK focusing on social norms and values are targeted towards the conservative Muslim population.

Little information is available on how the exam content and material have been devised in the countries examined. In Austria, the content of the exam has been criticised for the lack of transparency with which the exam content has been devised and the link to citizenship law (Stern and Valchars, 2013). Applicants for Austrian citizenship are required to demonstrate a basic knowledge of the democratic order and derived principles. However, Stern and Valchars (2013) note that the general principles are the subject of much debate among legal schools and far from common knowledge, and therefore note that the handbook for examinees has been criticised as portraying the subjective opinion of those responsible for its development.

Tests are conducted in the national language(s) of each country. Rocca et al. (2020) noted that civics tests thus often act as a form of language test, the required proficiency level of which is unspecified, and may in some cases exceed the level required for language requirements in those countries which include both requirements. In Hungary, where there is no language requirement for citizenship, the completion of a test on knowledge of history, geography, law, culture and 
literature in Hungarian is viewed by the authorities as a means of also testing language (EMN Hungary, 2019).

As shown in Table 4.1, costs to applicants vary widely across countries that require applicants to take an exam. In some countries, a separate cost applies to the taking of the test, while in others the cost of operating tests may form part of the overall cost for the citizenship application. Eight countries - Czech Republic, Denmark, Germany, Hungary, Lithuania, the Netherlands, Spain and the United Kingdom have put in place a separate charge for the test. Four countries - Austria, Croatia, Estonia and Latvia - do not impose a separate charge for the test.

In all countries requiring applicants to undertake an exam, exam materials, varying from handbooks and an inventory of questions to sample tests, are made available to applicants by the State or public entity operating exams on behalf of the State. Such materials are available to applicants free of charge in the majority of countries. In Hungary, Latvia and the United Kingdom applicants are charged for exam materials. Estonia and Hungary offer applicants free consultations in which information is provided on the operation of the exam and its contents (EMN Hungary, 2019). ${ }^{80}$ Latvia runs information days on applying for citizenship, during which applicants may undertake practice exams. ${ }^{81}$ Courses may also be available at a cost to applicants in order to assist applicants prepare for the exam in many of the countries examined. ${ }^{82}$

In Austria, Croatia, Hungary and Latvia the exams take place in national or local government offices. In seven countries, the exams are operated by national education and language agencies and institutions, ${ }^{83}$ and local education and language centres, on behalf of the State. ${ }^{84}$ In the UK, the exam is currently provided by a testing company, PSI Services, which operates in test centres around the country. ${ }^{85}$

In Austria, Croatia and Latvia the test forms part of the application processing procedure, whereby the test is taken either on submission of the application for

80 Innove, 'Examinations and exams/examinations-consultations.

consultations', www.innove.ee/en/examinations-and-tests/citizenship-

Office of Citizenship and Migration Affairs, Ministry of Interior of the Republic of Latvia, 'Examinations provided by the Citizenship Law', www.pmlp.gov.Iv/en/home/services/citizenship/registration-if-citizenship/naturalizacija/examinations.html.

82 Austria, Czech Republic, Germany, Hungary, Lithuania, Latvia, Slovakia, Spain, UK.

83 Estonia, Lithuania, the Netherlands, Spain.

84 Czech Republic, Denmark, Germany.

85 UK Home Office, 'Life in the UK test contract awarded', www.gov.uk/government/news/life-in-the-uk-test-contractawarded. 
naturalisation in person, ${ }^{86}$ or following submission of the application and during the processing period. ${ }^{87}$ In all other countries, the exam must be taken prior to submitting an application for naturalisation; a certificate of completion must be submitted with the application. In the Czech Republic, Lithuania and the Netherlands, civic knowledge/integration exam takes place at the same time as the language test. In Latvia, the civic knowledge test may only be taken following successful completion of the language exam. ${ }^{88}$

If an individual fails the exam on the first attempt, the exam can be repeated on payment of the exam fee in most countries. In Spain, the exam can be repeated once without having to pay, with subsequent attempts subject to the exam fee. ${ }^{89}$ In Hungary, if the individual fails only one of the two components of the exam (oral or written), they are only required to repeat the failed component, on payment of half of the exam fee (Pogonyi, 2013). In Latvia, applicants are also only required to repeat the failed section of the exam. However, a limit applies to applicants for Latvian citizenship. Applicants may repeat the exam up to three times, from one month after the previous exam attempt. If an applicant fails on the third attempt, the naturalisation application is terminated and the applicant is required to submit a fresh application for naturalisation. ${ }^{90}$

\subsection{INTERVIEWS AS CIVIC KNOWLEDGE ASSESSMENT}

In Bulgaria, France, Greece, Romania and Slovakia, knowledge is tested over the course of an interview. There is no specific integration or civic knowledge requirement set out in law in Bulgaria (Paskalev, 2013). ${ }^{91}$ However, on submission of an application for naturalisation at the Ministry of Justice, applicants must attend an interview conducted on the basis of a questionnaire, which can include questions on Bulgarian government, history and culture, and rights and obligations of citizens (EMN Bulgaria, 2019). In France, naturalisation applicants are required to show sufficient knowledge of French history, culture and society. ${ }^{92}$ Applicants have been required to prove 'assimilation' since 1927. The precise requirements to demonstrate assimilation were elaborated in 1993, 2003 and subsequently in

Croatia.

Austria, Latvia.

In Latvia, an applicant must take the citizenship test within two months of taking the language test, which must itself be taken within two months of submitting a citizenship application (see: Cabinet Regulation No. 973 (consolidated), 'Regulations Regarding Testing the Fluency in the Latvian Language and knowledge of the Basic Principles of the Constitution of the Republic of Latvia, the Text of the National Anthem, the Basics of the History and Culture of Latvia', available at https://likumi.lv/ta/en/en/id/260430-regulations-regarding-testing-the-fluency-in-the-latvian-languageand-knowledge-of-the-basic-principles-of-the-constitution-of-the-republic-of-latvia-the-text-of-the-national-anthemthe-basics-of-the-history-and-culture-of-latvia). Instituto Cervantes Exams, 'How much does the CCSE test cost', https://examenes.cervantes.es/es/ccse/cuanto.

90 Office of Citizenship and Migration Affairs, Ministry of Interior of the Republic of Latvia 'Examinations provided by the Citizenship Law',

www.pmlp.gov.lv/en/home/services/citizenship/registration-if-citizenship/naturalizacija/examinations.html.

91 Bulgarian Citizenship Act, available at http://data.globalcit.eu/NationalDB/docs/Bulgarian\%20Citizenship\%20Act\%20\%20bilingual_4.pdf.

92 French Civil Code, Article 21(24). 
2011 to incorporate knowledge of language, knowledge of the rights and duties of citizens and knowledge of French history, culture, essential principles and values, respectively. ${ }^{93}$ Initially tested by way of a questionnaire, an applicant's knowledge is now verified in the course of an interview conducted by local authorities on submission of a naturalisation application (EMN France, 2019; Hajjat, 2013). In Greece, an applicant for naturalisation is required to attend an interview before a Naturalisation Committee, which issues its opinion as to whether or not to grant the applicant citizenship (EMN Greece, 2019). As part of this interview, the Committee asks the applicant questions relating to Greek history and culture (Christopoulos, 2013). The Committee comprises three members of the Ministry of Interior, a member of faculty of a higher education institution specialising in sociology and a member specialising in psychology. ${ }^{94}$ Similarly, in Romania, an applicant is required to attend an interview before a Commission for Citizenship within the Ministry of Justice's National Authority for Citizenship, during which the applicant's language and knowledge of the Constitution and national anthem and Romanian history, geography, art and literature, are assessed (Barbulescu, 2013). ${ }^{95}$ In Slovakia, an applicant is required to attend an interview with a three-member Commission nominated by the local authority when filing a naturalisation application. During the interview, the Commission assesses the applicant's knowledge of the Slovak language, which includes questions relating to history, geography, social and political developments in the Slovak Republic. ${ }^{96}$

In both Romania and Slovakia, there are no guidelines on the level of knowledge required in order to naturalise. Barbulescu (2013) notes that there are no clear publicly available guidelines on what constitutes sufficient knowledge of language and culture to pass the interview in Romania. Kusá (2013) also notes that the naturalisation test in Slovakia is not regulated by any guidelines, there is no study material available to prepare for it, and the commissions set up at the District Authority for this purpose exercise significant discretion in the administration of the assessment and its evaluation. In Greece, applicants are provided with a booklet containing information on Greek history, culture, geography and civics, freely available on the Ministry of Interior's website. ${ }^{97}$ While naturalisation applicants in France are provided with a publicly available information manual, the Migration Policy Group and France Terre d'Asile (2018) highlight that there is a November 2003 to 18 June 2011.

94 Law 2910/2001 Entry and residence of foreigners in the Greek territory: Acquisition of Greek Citizenship by Naturalisation and Other Provisions, as amended by Law 3284/2004, Law 3838/2010 and Law 4604/2019, available at http://globalcit.eu/national-citizenship-laws//?search=1\&country=Greece.

95 Ministry of Justice National Authority for Citizenship, 'Categories of applications: Article 8', http://cetatenie.just.ro/index.php/ro/categorii-cereri/articol-8.

96 Collection of Laws No. 502/2007, Act on nationality of the Slovak Republic, available at Ministry of the Interior of the Slovak Republic, 'Citizenship', www.minv.sk/?statne-obcianstvo-1.

97 Hellenic Republic Ministry of Interior, 'Greek citizenship test resource book', www.ypes.gr/en/greek-citizenship-testresource-book/. 
need for clear guidelines for integration interviews to avoid unequal implementation and treatment at local level.

\subsection{INTEGRATION COURSES}

In contrast to most other Member States in which an exam is commonplace, naturalisation applicants in Belgium and Luxembourg may satisfy civic/integration requirements through completion of an 'integration' course.

In Belgium, applicants are required to prove 'social integration' in order to acquire citizenship. Unlike most other countries that use an exam as a means for citizenship applicants to provide evidence of civic knowledge/integration, Belgium offers applicants a range of options to satisfy integration requirements, one of which is providing a certificate confirming attendance at an integration course (see Section 5.2 for a case study on Belgium).

In Luxembourg, naturalisation applicants are required to attend the 'Living together in the Grand Duchy of Luxembourg' course. The course involves 24 hours of tuition, taught in course units of two hours. Applicants may alternatively choose to undertake an exam covering the topics taught in the course without needing to attend the course itself. The course and test consist of three modules:

- Fundamental rights of citizens (six hours);

- State and local institutions (12 hours);

- History of Luxembourg and European integration (six hours). ${ }^{98}$

A certificate issued on completion of the course or test must be submitted as part of the naturalisation application. The Adult Training Service of the Ministry of Education, Children and Youth is responsible for organisation of the course and exam. There is no charge for the course or exam. The requirement may be reduced to 18 hours for persons who already hold a certificate attesting attendance at citizenship training classes as part of a Reception and Integration Contract. ${ }^{99,100}$ The course and exam can be held in the three official languages of Luxembourg -

Amended Law of 8 March 2017 on Luxembourgish nationality and abrogating the Law of 23 October 2008 on Luxembourgish nationality and Law of 7 June 1989 on the transposition of surnames and name of persons who acquire or reclaim Luxembourgish nationality, Official Journal of the Grand-Duchy of Luxembourg, available at http://data.legilux.public.lu/file/eli-etat-leg-loi-2017-03-08-a289-jo-fr-pdf.pdf.

Lifelong-learing.lu, 'Training courses connected with acquiring Luxembourgish nationality' www.lifelonglearning.lu/Detail/Article/Formations/formations-liees-a-la-naturalisation/en.

100 The Reception and Integration Contract (Contrat d'Accueil et d'Intégration) is an optional reciprocal undertaking between the State and any foreign national aged 16 or older and living in the Grand Duchy legally and wishing to stay. It is optional, and open to citizens of countries both inside and outside the European Union, for people newly arriving and those who have been living in the Grand Duchy for years. It lasts two years, during which time the signatory undertakes to learn a language, attend civic instruction classes, and take part in an orientation day. 
French, German and Luxembourgish - in addition to English. ${ }^{101}$ EMN Luxembourg reported that the course programme and questions on the exam were devised by the Department of Adult Education of the Ministry of National Education in collaboration with course instructors (EMN Luxembourg, 2019).

\subsection{EXEMPTIONS AND ADAPTED REQUIREMENTS}

In an examination of Council of Europe member states, Rocca et al. (2020) found that very few countries provide systematic exemptions from knowledge of society requirements or facilitated access for vulnerable groups such as minors, refugees, or migrants with low levels of literacy. Most countries provide that certain groups of applicants may be exempt from satisfying civic knowledge/integration requirements, such as on the basis of age, illness, prior education in the country, and disability.

One of the most common exemptions applied by the countries examined in this report related to age. Children are exempt from meeting requirements in nine countries, with the minimum age ranging from $14,{ }^{102} 15,{ }^{103} 16,{ }^{104}$ and 18 years. ${ }^{105}$ Older persons are also exempt from requirements from 60 years of age in Croatia and 65 years of age in the Czech Republic, Hungary, Lithuania, and the UK. Persons over 70 years of age may apply for an exemption in Spain. Provision was also made for exemptions for applicants who had attained a certain level of mainstream education in the language of the country. ${ }^{106}$ In such cases, applicants are required to submit certification showing the required level of education has been obtained. Persons with a physical or mental illness that prevents them from undertaking a test or course are also exempt in certain countries. ${ }^{107}$

Exemptions are also expressly provided for persons with disabilities (see also Waddington, 2013). ${ }^{108}$ In Denmark, Estonia, Latvia and Spain, what is classified as a disability for the purpose of exemption is set out in regulations or information for applicants. ${ }^{109}$ In other countries, the term disability is kept broad and undefined, or is included within exemptions relating to the health status of an

Luxembourg Ministry of Education, Children and Youth, 'Courses and exams for acquiring Luxembourgish nationality', www.men.public.lu/fr/formation-adultes/integration-nationalite/cours-examen/index.html. 
applicant. ${ }^{110}$ The UK includes provisions in their guidelines on the Life in the UK test to guide the use of discretion on a case by case basis for persons with disabilities. ${ }^{111}$ Three Member States permit and/or provide for measures to facilitate participation of people with a disability in exams, such as in relation to preparation materials, assessment methods and requirement levels. ${ }^{112}$ In Spain, if a person with a disability does not meet the criteria for an exemption, they may apply for adapted examination procedures. ${ }^{113}$ The use of assistive devices, the presence of an assistant or transcriber, or extension of time allocated to the exam, for example, may be permitted and the approach is detailed in guidance for examinees (Instituto Cervantes, 2020). Similarly in Luxembourg, an individual may apply for reasonable accommodations to be made, such as to the physical environment of the examination centre, holding of examinations in an applicant's home, presence of an assistant, or technological aids. ${ }^{114,115}$

Few countries provide for exemptions or facilitative measures for illiterate people or persons with low literacy in citizenship law. In Spain, persons who are illiterate may apply for a waiver or an adapted exam (Instituto Cervantes, 2020).

As with language requirements, requirements to demonstrate knowledge of civics/society are not only linked to the acquisition of citizenship, but also increasingly form part of requirements for obtaining residence permission, family reunification and permanent residence (Strik et al., 2010). In certain countries, naturalisation applicants may be exempt from completing civic knowledge/integration requirements, if they have already met such requirements when applying for residence permission or permanent residence. This applies to applicants in the UK and the Netherlands, where civic knowledge/integration requirements are included as part of temporary and permanent residency application processes. In countries such as Belgium where people are obliged to follow integration courses following arrival at regional level, and some groups of migrants are required to show evidence of efforts to integrate to maintain a residence permission, proof of satisfying such requirements can also be submitted for the purposes of subsequently applying for nationality (see Section 5.2).

\footnotetext{
110 Austria, Belgium, Czech Republic, Germany, Hungary, Latvia, Lithuania.

111 UK Home Office, 'Knowledge of language and life in the UK', available at www.gov.uk/government/publications/knowledge-of-life-and-language-in-the-uk.

Denmark, Luxembourg, Spain.

EMN ad hoc query number 2020.38 (forthcoming).

Ibid.

Amended Law of 8 March 2017 on Luxembourgish nationality and abrogating the Law of 23 October 2008 on Luxembourgish nationality and Law of 7 June 1989 on the transposition of surnames and name of persons who acquire or reclaim Luxembourgish nationality, published in Memorial A-289 of 17 March 2017, available at http://data.legilux.public.lu/file/eli-etat-leg-loi-2017-03-08-a289-jo-fr-pdf.pdf, Article 16(4).
} 


\subsection{EVALUATIONS OF CIVIC KNOWLEDGE / INTEGRATION REQUIREMENTS}

Little information is available on the extent to which countries that have a knowledge of society/civic integration requirement linked to citizenship base their testing on research or evidence. In the EMN study Pathways to Citizenship, National Contact Points (NCPs) were asked whether civic tests had been the subject of evaluation. Most countries examined reported that there have been no evaluations of civic requirements in the context of acquiring citizenship. ${ }^{116}$ Where countries reported evaluations, civic requirements were assessed only in the context of broader reviews of the operation of the naturalisation procedure, rather than the impact of such measures. France reported that in 2017 the General Inspectorate of Administration reviewed the operation of the naturalisation process, including the assimilation interview, however the outcome of this report was not made public (EMN France, 2019). Bulgaria reported that an internal review of questions included in the interview questionnaire was undertaken (EMN Bulgaria, 2019). While Estonia reported that the citizenship test has not been evaluated, the Estonian integration monitor found in 2017 that non-nationals report one of the main reasons for not having Estonian citizenship is the difficulty of the citizenship test (EMN Estonia, 2019; Kaldur et al., 2017).

Some independent research funded by the EU Integration Fund has looked at migrants' views on language and civic integration requirements. Strik et al. (2010) conducted interviews with migrants as part of a research project on integration requirements at the pre-entry, permanent residence and naturalisation stages in nine EU countries. The research noted that examinations testing language and societal knowledge were generally supported by interviewees. However, they reported that civic requirements were less well received than language requirements in countries that had both in place. In the UK, a minority of migrants interviewed reported that they found the material in the Life in the UK handbook important, however some were of the view that the test was questionable as it set a standard that many UK-born residents would not be able to meet. Strik et al. (2010) also found that while the Life in the UK test was relatively straightforward for those who could speak English, it was more difficult for those with a lower level of English, particularly people who had little formal education and who lacked computer literacy. In the Netherlands and Denmark, interviewees also felt that they were required to learn material that not all citizens born in the country would know. However, some interviewees in the Netherlands reported that they were better able to manage after the integration course. In Germany, while interviewees did not find the content difficult, they questioned the relevance of the test in

116 For further information, see templates submitted by EMN NCPs for the EMN study on Pathways to citizenship for thirdcountry nationals in the EU, available at https://ec.europa.eu/home-affairs/what-wedo/networks/european_migration_network/reports_en. 
becoming a German citizen. Most migrant interviewees were of the opinion the naturalisation tests in Denmark, Germany, Latvia and the UK did not contribute to their integration. The research also found that non-immigrant interviewees (teachers, NGOs, public officials) across the countries examined were reluctant to state that integration requirements contributed to the migrant integration process. The study reported that that fear of the examination, and lack of Latvian courses, appeared to be a major reason for not applying for Latvian citizenship (Strik et al., 2010). Similarly, interviewees in Hungary found that the high level of knowledge of Hungarian required for the civic test and the lack of free language courses was a hindering factor to acquiring citizenship (Strik et al., 2010; Tóth, 2010).

Gidley et al. (2012) carried out research on the process of integration and acquisition of citizenship in the UK to inform integration policy, including some discussion of the Life in the UK test. The research was based on a quantitative survey of a large, representative sample of successful and unsuccessful applicants for British citizenship and qualitative interviews and focus groups with applicants and those who had chosen not to apply. The report found that those who had experience of the Life in the UK learning materials and test were broadly satisfied with the experience. However, it was noted that only some of the applicants from non-English-speaking countries found the language of the learning materials easy to understand. In a later study conducted with people who had taken the test, participants found that while the knowledge gained was useful and interesting they did not view the information as critical and were of the view the test consisted of facts that many UK born citizens would not know (Byrne, 2017). Similar findings were highlighted by Bassel et al. (2017), in which most research participants viewed the test as created for political or ideological reasons. Bassel et al. (2017) also found that while some participants saw the test as an opportunity to improve English language skills, others found the test to be a barrier, including applicants from non-English speaking countries, who often found the test more stressful.

Evaluations have been carried out on integration courses in countries such as Belgium (De Cuyper and Wets, 2007; Geets et al., 2007; De Cuyper et al., 2010; De Cuyper, 2010; Pauwels and Lamberts, 2010; Gossiaux et al., 2019), Germany (Schuller et al., 2011) and the Netherlands (Gelderloos and van Koert, 2010); however these evaluations do not examine the link between integration requirements and the acquisition of citizenship.

\subsection{CONCLUSIONS}

This chapter shows that civic integration/knowledge requirements have been gradually introduced by EU Member States and the UK as part of citizenship law and policy, particularly over the past two decades. Eighteen EU Member States and 
the UK currently require applicants to demonstrate civic knowledge or 'integration' as part of the naturalisation process. However, this chapter shows there is a diverse range of approaches to such requirements across EU Member States and the UK, with practice varying from written exams, attendance at an interview with an immigration official or naturalisation committee, or completion of an integration course.

The knowledge assessed typically relates to the country's Constitution, political system, history and customs, with some countries requiring applicants to also respond to questions on social norms and values. Tests, interviews and courses primarily take place in the official language(s) of the country, thus the ability to satisfy civic requirements also demands a certain level of proficiency in the official language(s). All but three countries that require applicants to take an exam apply a specific exam fee for applicants, in addition to the cost of applying for citizenship. Applicants undertaking exams generally have access to preparation materials free of charge, however materials are provided by the State at a cost in a small number of countries. In contrast, there is a lack of clear guidance for applicants in the countries that require attendance at an interview.

The use of exemptions and adapted assessment methods varies significantly across countries. Most countries provide exemptions for certain groups of applicants based on age, prior education, illness or disability. However, very few countries provide adapted assessment methods for people with disabilities or people with low levels of literacy or formal education to enable them to satisfy requirements. Countries that have introduced requirements report that no evaluations of the impact of such requirements on integration have been conducted. Little is therefore known about the impacts of including civic knowledge/integration requirements in the citizenship process and whether these requirements meet their stated aim of facilitating integration into the host society. Scholars examining citizenship requirements highlight how tests may act as either an incentive for acquiring skills and integration or as a deterrent to applying for naturalisation, however little is known of the effect of these measures on encouraging, or indeed deterring, migrants to apply for citizenship (Strik et al., 2010). Some independent research conducted by academics with people who are subject to such requirements report mixed views of the usefulness of requirements, with participants in some countries reporting that requirements represent a barrier to applying for citizenship. Defining the content of such tests can be challenging, both in terms of the knowledge required, which implies an understanding of what a 'good citizen should know', but also in terms of the level such a test is set at, and how much applicants for naturalisation are expected to know. 



\section{CHAPTER 5}

\section{Case studies}

\section{$5.1 \quad$ INTRODUCTION}

This chapter presents four European case studies as well as an overview of requirements in three English-speaking countries outside of Europe. When selecting the case studies we focussed on countries with significant potential for learning in Ireland. Within Europe, we looked for countries with commonalities with Ireland, as discussed individually below. We also sought diversity of experience in order to look at how naturalisation requirements have evolved in different contexts, as well as particularly interesting practices to investigate further. English-language speaking settler countries provide a perspective on countries with a much longer tradition of civics and language testing. Below we discuss the cases of Belgium, Finland, Portugal and the United Kingdom, as well as a group of English-speaking countries outside of Europe: Australia, Canada and the United States.

TABLE 5.1 SUMMARY OF REQUIREMENTS IN SELECTED CASE STUDIES

\begin{tabular}{l|l|l}
\hline \multicolumn{1}{c|}{ Country } & \multicolumn{1}{|c}{ Language requirement } & \multicolumn{1}{c}{ Civic knowledge/integration requirement } \\
Belgium & Dutch, French or German & $\begin{array}{l}\text { 'Social integration' evidenced by various } \\
\text { means, including an integration course }\end{array}$ \\
\hline Finland & $\begin{array}{l}\text { Finnish, Swedish, Finnish sign language or } \\
\text { Swedish sign language used in Finland }\end{array}$ & No requirement \\
\hline Portugal & Portuguese & No requirement \\
\hline UK & English, Scottish or Welsh & Life in the UK exam \\
\hline
\end{tabular}

Finland was selected as case study country due to commonalities shared with Ireland. The two countries are a similar size and at the peripheries of the EU. Both countries have multiple national languages. In terms of the national approach to citizenship and integration, the former is viewed as enabling instead of rewarding integration (Goodman, 2010). Historically, like Ireland, Finland was a country of emigration rather than immigration (OECD, 2018a). Belgium was selected as a case study country as it adopts an approach that differs somewhat from other EU Member States. Belgium has three official languages and citizenship applicants can satisfy civic and language requirements through completion of an integration course, rather than sitting an exam, as required in the majority of other countries. Although in contrast to Ireland, Belgium is a long-standing destination for migrants (OECD, 2018a), along with Ireland it has one of the highest percentages of foreignborn residents among EU Member States. When it comes to Portugal, the selection of this country as a case study was based on the fact that, like Finland, it became 
an immigration country relatively recently. Also Goodman (2010) clustered Portugal in the group of states enabling migrant integration. Portugal offers multiple pathways to attesting knowledge of language which it developed over a short period of time. Finally, the United Kingdom is selected on the basis that it has been one of the main immigration destinations in Europe with a long standing tradition. Both language tests and civic requirements are applied in the United Kingdom and sitting a test is the main way to meet the requirements. In addition UK citizenship law offers applicants the possibility of meeting the requirements in three languages.

These four case studies focusing on European states are complemented by an overview of requirements related to naturalisation in three non-European countries: the United States, Canada and Australia. These countries are viewed in literature as the pioneers in introducing requirements related to naturalisation and while their experiences might differ from the European context, they serve as important points of reference.

\subsection{CASE STUDY 1: BELGIUM}

\subsubsection{Background}

Belgium is a federal state made up of three Communities (Flemish, French and German-speaking communities) and Regions (Flemish Region, Walloon Region and Brussels Capital region). Belgium has three official languages: Dutch, French and German. Dutch is currently the language spoken by the majority of people in Belgium, being the official language of the Flemish region and, along with French, an official language of the Brussels-Capital Region. French is the official language of the Walloon region. ${ }^{117}$

Prior to World War I, Belgium was primarily a country of emigration, however immigration significantly increased from the 1920s (Lafleur and Marfouk, 2019). Belgium's migration flows have been shaped particularly by migrant workers with low levels of educational attainment in the post-war period, followed by large inflows of family migrants (OECD, 2018a). More than half of immigration flows to Belgium are comprised of EU nationals (Lafleur and Marfouk, 2019). Family reasons comprise the second highest reason for migration to Belgium, followed by humanitarian migrants and labour migrants (OECD, 2019).

117 The German-speaking community covers nine municipalities located in the Walloon region and comprises less than 1 per cent of the population. 
Most recent figures on the foreign-born population as of 1 January 2019 show that 1,968,060 people were foreign-born, comprising 17 per cent of the Belgian population. Non-EU nationals made up 9 per cent of the population, while 8 per cent of the population were EU nationals. ${ }^{118}$ The main countries of birth of the foreign-born resident population include Morocco, France, the Netherlands, Italy, Turkey, Romania and the Democratic Republic of the Congo. ${ }^{119}$ Data show that immigration flows and the share of migrants among the resident population varies significantly across regions, with migrants making up almost 45 per cent of the total population in the Brussels Capital Region (Noppe et al., 2018; Lafleur and Marfouk, 2019). In 2018, 36,200 people were granted Belgian nationality, down from 37,399 in 2018. ${ }^{120}$ Non-EU nationals comprised 68 per cent of those granted Belgian nationality. ${ }^{121}$ The Flemish region accounts for the largest number of people acquiring nationality in Belgium; however, the number of acquisitions relative to the population is approximately three times higher in the Brussels-Capital region (Noppe et al., 2018).

Applicants for Belgian nationality are required to satisfy civic and language requirements and have a variety of avenues to do so, including through completion of an integration course. This case study will focus in particular on the role of integration courses in the citizenship framework. It is important to note that naturalisation in Belgium is related only to non-nationals who can demonstrate exceptional achievements in the scientific, sport or sociocultural domain, ${ }^{122}$ and to stateless persons whose status of statelessness is legally recognised and who have resided in Belgium for at least two years. ${ }^{123}$ Non-nationals who wish to apply for Belgian nationality having resided in Belgium instead apply for nationality through declaration. ${ }^{124}$ This method of applying for citizenship requires that a declaration be lodged with the civil registrar of the local authority of the individual's main residence in Belgium and is viewed as a right to which applicants who meet the conditions for the acquisition of nationality are entitled.

\subsubsection{Citizenship context}

Authority for legislating on Belgian nationality is held at the federal level. The decision as to whether or not a person can acquire Belgian nationality lies with the local authority, consulates and the Public Prosecutor. ${ }^{125}$ However, authority for policies on integration and reception of migrants and language policy are within

Eurostat, 'Population on 1 January by age group, sex and country of birth [migr_pop3ctb]' (Data accessed June 2020). Ibid.

Eurostat, 'Acquisition of citizenship by age group, sex and former citizenship [migr_acq]' (Data extracted June 2020).

Ibid.

Code of Belgian Nationality, Article $19 \S 1$.

Code of Belgian Nationality, Article $19 \S 2$.

Declaration is governed by Article 12 bis of the Code of Belgian Nationality, which was introduced in 1991 by way of legislation, but only applied to persons born in Belgium until 2000. 
the remit of each Community. In the Brussels-Capital region, the Flemish Community and French Community ${ }^{126}$ are each competent in relation to integration and reception. The Common Community Commission also regulates and manages matters common to the two communities in the Brussels Capital Region (EMN Belgium, 2018).

The current rules governing the acquisition of citizenship have their basis in the 1984 Code of Belgian Nationality. ${ }^{127}$ The 1984 Code required citizenship applicants to show proof of a 'willingness to integrate', reflecting the Code's key principle that the acquisition of Belgian nationality would promote the further integration of foreign-born residents. ${ }^{128}$ There were no explicit language requirements in law at the time. In light of concerns that the undefined and broad nature of the condition led to arbitrary decision-making, reforms introduced in 2000 removed the condition to prove a willingness to integrate. ${ }^{129}$ In the period between 2000 and 2012, naturalisation applicants were not subject to integration requirements as a matter of law. ${ }^{130}$ This reflected the prevailing view that acquiring Belgian nationality served as an instrument of integration, and the making of an application was itself considered as sufficient proof of willingness to integrate. ${ }^{131}$

Significant reforms made to the Code of Belgian Nationality in 2012 brought about important changes to the law in relation to language and integration requirements. The law established a 'social integration requirement' and language requirement, thereby reintroducing the concept of integration into Belgian nationality law (De Jonghe and Doutrepont, 2013a). The law reflected a shift in the way in which nationality was viewed in the context of integration. The legislature argued that new Belgians did not always integrate after acquiring Belgian nationality. ${ }^{132}$ It was argued that integration was 'essential to improve relations between different ethnic groups and maximise the chances of success of a harmonious model of society'. ${ }^{133}$ The acquisition of nationality was thus viewed as a consequence, or the

126 The French Community transferred its competence on integration and reception matters to the Walloon Region and French Community Commission.

127 Code of Belgian Nationality, 28 June 1984, Belgian Official Gazette, available at www.ejustice.just.fgov.be/cgi_loi/change_lg.pl?language=fr\&la=F\&table_name=loi\&cn=1984062835.

128 Belgian Chamber of Representatives, Bill relating to certain aspects of the status of foreigners and establishing the Code of Belgian nationality, 17 October 1983, Parliamentary Document 756/1, available at www.dekamer.be/digidoc/DPS/K2036/K20361443/K20361443.PDF.

129 Law amending certain provisions relating to Belgian nationality, 1 March 2000, Belgian Official Gazette, available at www.ejustice.just.fgov.be/eli/loi/2000/03/01/2000009306/moniteur.

130 See Foblets et al. (2013) however for a discussion of how in some municipalities applications were still rejected by local officials on the basis of a perceived lack of integration, particularly where it appeared an applicant lacked sufficient knowledge of one of the national languages.

131 Belgian Chamber of Representatives, Bill relating to certain aspects of the status of foreigners and establishing the Code of Belgian nationality, 29 November 1999, Parliamentary Document 50-0292/001, available at www.dekamer.be/FLWB/PDF/50/0292/50K0292001.pdf.

132 Information obtained from FPS Justice, March 2020.

133 Belgian Chamber of Representatives, Bill modifying the Code of Belgian Nationality in order to neutralise the effects of the acquisition of Belgian nationality on immigration, 27 October 2010, Parliamentary Document 53-0476/001, available at www.dekamer.be/FLWB/PDF/53/0476/53K0476001.pdf. 
final step, and no longer an instrument, in the integration progress (De Jonghe and Doutrepont, 2013a)..$^{134}$

Currently, persons can apply for nationality through declaration on the basis of their residence in the country, if they meet the following conditions: 1 ) attained 18 years of age; 2 ) have resided in Belgium for five years; 3 ) prove knowledge of one of the three national languages; 4) prove 'social integration'; and 5) prove 'economic participation'. 135

\subsubsection{The 'social integration' requirement and integration courses}

While the concept of integration itself is not defined in law, the legislation sets out the means by which an applicant for Belgian nationality can prove their social integration. Unlike most other countries that use an exam as a means for citizenship applicants to provide evidence of 'integration' or knowledge of society, Belgium offers applicants a range of options to satisfy integration requirements. 'Social integration' can be evidenced through one of the following options:

- A diploma or certificate issued by an educational institution organised, recognised or subsidised by one of the three Communities or the Royal Military Academy at a minimum level equivalent to that of upper secondary education; or

- Completion of a professional training course of at least 400 hours recognised by a competent authority; or

- Proof of uninterrupted activity as an employee/self-employed/statutorily appointed as an official in the government service for a period of at least five years preceding the application; or

- The successful completion of an integration programme, reception programme or integration trajectory evidenced by a certificate or attestation issued by the competent authority of the applicant's primary residence. ${ }^{136}$

Attendance at an integration course was particularly viewed by the legislature as contributing to successful integration and to the harmonious co-existence of persons of different origins', ${ }^{137}$ and a means for persons who are not in

134 Information obtained from FPS Justice, March 2020.

135 Citizenship by declaration also applies, subject to varying conditions, to: persons over the age of 18 who were born and have resided since birth in Belgium; people who are married, or are parent, to a Belgian national; and persons over the age of 18 who have resided in Belgium for ten years. Persons born in Belgium do not have to satisfy language or 'social integration' requirements. Persons who have resided in Belgium for ten years must satisfy the language requirement and must prove their participation in the economic or sociocultural life of their community (Code of Belgian Nationality, Article 12bis).

136 Code of Belgian Nationality, Article 12bis§1, $2^{\circ}(\mathrm{d})$, Belgian Official Gazette, available at www.ejustice.just.fgov.be/cgi_loi/change_lg.pl?language=fr\&la=F\&table_name=loi\&cn=1984062835.

137 Belgian Chamber of Representatives, Bill modifying the Code of Belgian Nationality in order to neutralise the effects of the acquisition of Belgian nationality on immigration, 27 October 2010, Parliamentary Document 53-0476/001, available at www.dekamer.be/FLWB/PDF/53/0476/53K0476001.pdf. 
employment or who have not undertaken education or training in Belgium to apply for nationality. When first enacted, applicants were only required to show proof of having followed an integration programme. However legislation adopted in 2018 imposed a stricter requirement according to which applicants must provide proof of having successfully completed an integration programme. ${ }^{138}$

In recent years, similar integration requirements have been introduced for the granting of residence permissions to non-EEA nationals. Since 2017, non-Belgian nationals authorised to stay in Belgium for longer than three months are required to show evidence of their willingness and efforts to integrate into society in order to maintain their residence permission. ${ }^{139}$ The Belgian Immigration Office has the power to end the individual's residence permission, if it is of the view that reasonable efforts to integrate have not been made. The Immigration Office must take into account a number of criteria, including attendance at an integration course, as well as other criteria similar to those for satisfying the 'social integration' requirement for the acquisition of nationality (EMN Belgium, 2018). ${ }^{140}$

In line with the division of legislative power, integration courses are governed at Community level. Such courses had already been in place since the 1990s in the French Community and early 2000s in the Flemish Community, prior to their link to the acquisition of citizenship being established in nationality law.

\section{Flemish Community}

In 2003, the Flemish authorities enacted the Flemish Decree on Integration Policy, ${ }^{141,142}$ which introduced mandatory courses for certain groups of migrants. Adam and Martiniello (2013) note that public debate in relation to the perceived failure of integration policies had an impact on the development of integration policy in Flanders, with the introduction of mandatory civic integration programmes being presented as a new policy that responds to policy errors made in the past. The courses are mandatory for migrants, aged at least 18 , who are

Information obtained from FPS Justice, March 2020. Law laying down various provisions concerning civil law and provisions to promote alternative forms of dispute resolution, 18 June 2018, Belgian Official Gazette, available at www.ejustice.just.fgov.be/cgi_loi/change_Ig.pl?language=fr\&la=F\&table_name=loi\&cn=2018061803. protection applicants; recognised refugees, subsidiary protection beneficiaries and stateless people, and their family members; Turkish nationals admitted in line with the Ankara Agreement; victims of human trafficking; international students; highly qualified non-EEA nationals; and non-EEA national seasonal workers.

140 Law inserting a general residence condition into the Law of 15 December 1980 on access to the territory, stay, settlement and removal of foreign nationals, 18 December 2016, Belgian Official Gazette, available at www.ejustice.just.fgov.be/eli/loi/2016/12/18/2017030051/justel.

141 The decree came into effect on 1 April 2004. Flemish Community, Decree on the Flemish integration policy, 28 February 2003, Belgian Official Gazette, available at www.ejustice.just.fgov.be/eli/decreet/2003/02/28/2003035383/staatsblad.

142 The original decree has been amended several times and was replaced by a decree in 2013, which forms the basis for the current policy framework. Flemish Community, Decree on the Flemish integration and civic integration policy, 7 June 2013, Belgian Official Gazette, available at www.ejustice.just.fgov.be/eli/decreet/2013/06/07/2013204197/staatsblad. 
authorised to stay for more than three months in Belgium and who have been registered in a Flemish local municipality for less than 12 months, non-EU spouses of Belgian nationals and long-term migrants availing of social benefits. The courses are voluntary for other groups, such as nationals of the EU, EEA and Switzerland.

The integration programme is divided into two parts, the first of which seeks to foster self-reliance and includes a Dutch language course, social orientation and career guidance, and the second of which consists of an optional follow-up programme tailored to the needs of the individual (Xhardez, 2016). The social orientation course consists of knowledge of rights and obligations, the workings of Belgian society, and values and norms, and can be provided in Dutch, in the language of the country of origin of the migrant or in a contact language. Participants are also guided throughout the programme by a counsellor. A certificate of completion is provided to participants on successful completion of the course. Participants were initially only required to complete the course to receive a certificate. However, legislation adopted in 2016 requires participants to demonstrate they have obtained a minimum level of results in order to receive a certificate (OECD, 2018b). ${ }^{143}$ The integration course must be completed within a year of commencement. However, flexible conditions for completion of the course can apply for medical or personal reasons, in the case of persons in employment who cannot combine work and the regular course, and persons who are following a literacy course (EMN Belgium, 2018). The integration programme is provided at no cost to the applicant. However, if the participant fails to complete the course, they may be sanctioned with an administrative fine. The integration courses are implemented by the Flemish Agency for Integration and Civic Integration and two local agencies, IN-Gent in Ghent and Atlas in Antwerp.

\section{Walloon region}

In 1996, the Walloon region adopted a decree establishing regional integration centres that offered linguistic and civic integration courses to immigrants on a voluntary basis (Strazzari, 2016). Prior to 2015, there was no standardised integration course across the Walloon region; a proposal for a decree to introduce a common voluntary integration course in 2003 was unsuccessful (Adam and Martiniello, 2013).

The introduction of the 'social integration' requirement in 2012, at a time when only the Flemish community had in place a standardised integration course, gave rise to concerns that such requirement would lead to a divergence across communities (De Jonghe and Doutrepont, 2013b; CBAI CRAcs, 2016). In 2014, the

143 Flemish Community, Decree of the Flemish Government concerning the implementation of the decree of 7 June 2013 regarding the Flemish integration and integration policy, 29 January 2016, Belgian Official Gazette, available at www.ejustice.just.fgov.be/eli/besluit/2016/01/29/2016035410/staatsblad. 
Walloon region adopted a decree revising its integration policy and introducing a two-step integration path operated by reception offices for newcomers. ${ }^{144}$ The first part is compulsory and involved an assessment of social and linguistic skills in order to provide vocational guidance, in addition to information provision on rights and duties. The second part was initially optional and consisted of a 'reception agreement', which includes a 120-hour French language course, 20 hours of citizenship training providing information on Belgian society and public institutions, and vocational guidance and support in administrative processes (Xhardez, 2016). Following the adoption of a decree in 2016, the entire programme became compulsory. ${ }^{145} \mathrm{~A}$ certificate of completion is subsequently offered to participants who complete such training. Courses are also free of charge to the applicant, however, should a participant not attend or complete training, they may be sanctioned with an administrative fine (Strazzari, 2016).

Integration courses are organised through eight regional integration centres across the Walloon region. The courses are provided by a platform of several actors operating under the umbrella of the regional integration centres, which includes Local Integration Initiatives (recognised non-profit organisations, local authorities, foundations, public utility establishments and international non-profit associations which carry out activities in relation to the integration of people with a migrant background), public authorities, education institutions, and centres of socioprofessional integration (Van de Pol and Vanheule, 2018).

\section{Brussels Capital region}

In the Brussels region, both the Flemish Community and French Community are competent in relation to policy on reception and integration of immigrants. Both Communities offer an integration programme to migrants free of charge, and the participant may choose which programme they wish to follow (Xhardez, 2016). The Flemish Community has offered the same integration programme in the Brussels Capital region as that offered in the Flemish region since 2004, governed by the Flemish Agency for Integration (Xhardez, 2016). The French Community Commission also adopts a similar approach in the Brussels Capital region to that offered in the Walloon region, with the introduction of a reception programme for newcomers in Brussels 2015. ${ }^{146}$ Two reception offices (Bureau d'acceuil pour primo-arrivants - BAPAs) established in 2016 operate the French reception

144 Public Service of Wallonia, Decree replacing Book II of the Walloon Code of Social Action and Health on the integration of foreigners or people of foreign origin, 27 March 2014, Belgian Official Gazette, available at www.ejustice.just.fgov.be/eli/decret/2014/03/27/2014202452/moniteur.

145 Public Service of Wallonia, Decree amending Book II of the Walloon Code of Social Action and Health relating to the integration of foreigners or persons of foreign origin, 28 April 2016, Belgian Official Gazette, available at www.ejustice.just.fgov.be/eli/decret/2016/04/28/2016202428/moniteur.

146 French Community Commission, Decree relating to the reception pathway for newcomers in the Brussels-Capital Region, 18 July 2013, Belgian Official Gazette, available at

www.ejustice.just.fgov.be/cgi_loi/loi_a1.pl?\&language=fr\&cn=2013071838\&caller=image_a1\&fromtab=loi. 
programme in Brussels, in conjunction with non-profit associations (Strazzari, 2016; Van de Pol and Vanheule, 2018). ${ }^{147}$

Courses in the Brussels Capital Region are currently voluntary. In 2017, the Common Community Commission in Brussels adopted an ordinance stating courses would become mandatory for people between 18 and 65 years of age who are resident in Brussels and who have lived in Belgium for less than three years with a residence permit valid for more than three months (OECD, 2019). ${ }^{148}$ The Flemish Community, French Community and Common Community Commission subsequently concluded a cooperation agreement in 2018 setting out the operation of integration courses in Brussels. ${ }^{149}$ However, the agreement has not entered into force to date.

\section{German community}

In the German-speaking community, mandatory integration courses were also introduced in 2018. ${ }^{150,151}$

\subsubsection{Language requirement}

An applicant for nationality by way of declaration must demonstrate knowledge of one of the three national languages, Flemish, French or German, at A2 level of the Common European Framework of Reference for Languages (CEFR). ${ }^{152}$ The introduction of a language requirement was proposed on the basis that language skills are viewed as paramount importance for social integration. ${ }^{153}$ There is no requirement in law to demonstrate knowledge of the language of the region in which the applicant resides (Foblets et al., 2013); knowledge of one of the three national languages suffices.

147 French Community Commission, Decision 2014/562 of the College of the French Community Commission of 24 Apri 2014 implementing the decree of 5 July 2013 relating to the reception pathway for newcomers in the Brussels-Capital Region, 24 April 2014, Belgian Official Gazette, available at

www.ejustice.just.fgov.be/cgi_loi/change_Ig.pl?language=fr\&la=F\&cn=20140424A5\&table_name=loi.

148 Common Community Commission, Order regarding the reception pathway for newcomers, 11 May 2017, Belgian Official Gazette, available at

www.ejustice.just.fgov.be/cgi_loi/change_Ig.pl?language=fr\&la=F\&cn=2017051109\&table_name=loi.

149 Common Community Commission, Cooperation agreement of 20 December 2018 concluded between the Flemish Community, French Community Commission and Common Community Commission relating to the compulsory reception pathway for newcomers in the Brussels Capital Region, 20 December 2018, Belgian Official Gazette, available at

www.ejustice.just.fgov.be/cgi_loi/change_lg.pl?language=fr\&la=F\&table_name=loi\&cn=2018122061.

150 Parliament of the German speaking community, Decree on integration and living together in diversity, 11 December 2017, Belgian Official Gazette, available at www.ejustice.just.fgov.be/eli/decreet/2017/12/11/2017206644/staatsblad.

151 Similar to the Flemish and French community integration courses, the course consists of a reception assessment, German language tuition, integration course and socio-professional orientation, and are run by the Info-Integration Centre free of charge (EMN Belgium, 2018).

152 Code of Belgian Nationality, Article 12 bis $\$ 1,2^{\circ}$ (c).

153 Belgian Chamber of Representatives, Bill modifying the Code of Belgian Nationality in order to neutralise the effects of the acquisition of Belgian nationality on immigration, 27 October 2010, Parliamentary Document 53-0476/001, available at www.dekamer.be/FLWB/PDF/53/0476/53K0476001.pdf. 
There are several means by which evidence of knowledge of one of the three national languages may be provided. Proof of knowledge of one of the three national languages will generally be deemed to be met once an applicant satisfies the 'social integration' requirement. ${ }^{154}$ Eight forms of proof are accepted, including language certificates, proof of employment or training, and certification of completion of an integration course. ${ }^{155}$ Language courses form part of integration courses in all three communities (Flemish, French and German) and the BrusselsCapital Region.

\subsubsection{Exemptions}

People who provide proof that they are unable to access employment or an economic activity due to disability or 'invalidity' may apply for nationality through declaration without having to satisfy the additional language or social integration requirements (Breda, 2013). ${ }^{156}$ Similarly, people who are unable to follow an integration course due to a disability or serious illness are exempt from the obligation to take part in an integration course at regional level in the Flemish and Walloon regions.

People who have reached pensionable age are also not required to meet language and social integration requirements. ${ }^{157}$ Persons born in Belgium that have legally resided in Belgium since birth are exempt from language and social integration requirements. ${ }^{158}$

154 Royal decree implementing the Law of 4 December 2012 amending the Code of Belgian Nationality to neutralise the effects of the acquisition of Belgian nationality on immigration, 14 January 2013, Belgian Official Gazette, available at www.ejustice.just.fgov.be/eli/arrete/2013/01/14/2013009022/moniteur.

$155 \mathrm{Ibid}$. The eight options are as follows:

1. A diploma or certificate issued by an educational institution organised, recognised or subsidised by one of the three Communities or the Royal Military Academy at a minimum level equivalent to that of upper secondary education, delivered in one of the three national languages;

2. A certificate of secondary education or higher obtained in another EU country that certifies knowledge of one of the three national languages at a minimum level of A2 CEFR level;

3. A document certifying the applicant completed a professional training course of at least 400 hours recognised by a competent authority;

4. A document certifying completion of an integration course;

5. A document certifying that the applicant has been employed/self-employed/appointed as a statutory agent to the public service continuously for the previous five years. Pulinx and Van Avermaet (2015) note that no evidence is explicitly required that the work was conducted in a Dutch, French or German speaking environment;

6. Certification of A2 level issued by an institution organised, recognised or subsidised by a Community;

7. A language certificate corresponding to $A 2$ level issued by the Federal Administration Selection Office; or

8. A certificate corresponding to A2 level issued by the Regional Offices for professional training and employment.

156 Code of Belgian Nationality, Article 12 bis $\S 1,4^{\circ}$, available at www.ejustice.just.fgov.be/cgi_loi/change_Ig.pl?language=fr\&la=F\&table_name=loi\&cn=1984062835 Ibid.

158 Ibid., Article 12bis $\S 1$. 


\subsubsection{Challenges}

Caritas International Belgium notes that, while the adoption of a similar approach to integration courses across regions is positive, the integration courses offer a one-size-fits-all approach, which does not take into account the needs of migrants and their levels of education (Lafleur and Marfouk, 2019). There are no provisions in the law in relation to people who are illiterate or have low levels of literacy (De Jonghe and Doutrepont, 2013b; Myria, 2017). The lack of such measures were raised in parliamentary debate on amendments to the Code of nationality and were highlighted as exclusionary towards persons who may speak fluent French, Flemish or German but have not had, or have low levels of, formal education. ${ }^{159}$ Measures have been put in place to tailor integration courses to illiterate persons, such as under the common agreement reached by the Communities in the Brussels-Capital Region, where it was proposed courses be set at level A1 competency in spoken language. ${ }^{160}$ However, it is unclear as to whether such measures are viewed as satisfying the requirements for citizenship. Myria (2017) therefore recommended that measures adapted to evaluating the language competency of illiterate persons, including facilitating oral exams, be introduced in legislation.

Myria (2017) also reported that in some districts the police, who are not qualified to evaluate language competency, have questioned applicants' knowledge of the language, despite the fact the law only requires submission of a certificate proving the required minimum level of knowledge for the purposes of the application by declaration.

Challenges have also been reported in respect of accessing integration programmes. While integration courses are provided at no cost to migrants, associated costs such as in relation to mobility and childcare may pose difficulties for individuals attending integration courses (Gossiaux et al., 2019). A lack of access to childcare (Myria, 2015; EMN Belgium, 2018), and difficulties linked to mobility, particularly where courses are not available in a local area (Gossiaux et al., 2019), were identified as barriers to accessing integration and language courses.

As stated above, integration programmes are organised at the Community level, and what may be recognised as an integration programme for the purposes of

159 Belgian Chamber of Representatives, Bill laying down various provisions concerning civil law and amending the Judicial Code in order to promote alternative forms of dispute resolution, 9 May 2018, Parliamentary Document 54-2919/006, available at www.dekamer.be/FLWB/PDF/54/2919/54K2919006.pdf.

160 Common Community Commission, Cooperation agreement of 20 December 2018 concluded between the Flemish Community, French Community Commission and Common Community Commission relating to the compulsory reception pathway for newcomers in the Brussels Capital Region, 20 December 2018, Belgian Official Gazette, available at www.ejustice.just.fgov.be/cgi_loi/change_Ig.pl?language=fr\&la=F\&table_name=loi\&cn=2018122061. 
acquisition of nationality is not defined in nationality law. The divergence in the content of integration programmes between Communities, and in the interpretation by local authorities of what may be recognised as an integration programme, were highlighted as a challenge that could lead to a difference in treatment of applicants according to the Community in which they reside (Apers, 2018). ${ }^{161}$

\subsubsection{Evaluations of the requirements for citizenship in Belgium}

There have been no evaluations of the requirements for acquiring citizenship relating to 'social integration' and language proficiency. Evaluations of integration courses have taken place at regional level. However, the evaluations do not focus on the link between integration courses and the acquisition of citizenship, or the impact of citizenship requirements themselves on the integration of migrants. The integration programmes in the Flemish region were the focus of independent evaluations in 2007 (De Cuyper and Wets, 2007; Geets et al., 2007) and 2010 (De Cuyper et al., 2010; De Cuyper, 2010; Pauwels and Lamberts, 2010), which examined the extent to which the integration courses pursued the policy objectives of self-reliance and participation by assessing the outcomes of individuals who had commenced an integration programme in 2005 and 2006. The study found that following an integration programme provides non-nationals with an advantage in acquiring information compared to those who did not take the course, although differences had often levelled out in many domains after a number of years. It also identified the need to tailor programmes to the specific needs of migrant groups according to their status and their skill/education level (De Cuyper et al., 2010; De Cuyper, 2010; Pauwels and Lamberts, 2010).

An evaluation of integration courses in the Walloon region was conducted in 2019 and sought to establish the impact of integration courses on integration and their coherence across the Walloon region. Course operators were found to appreciate the structure for provision of integration courses put in place by the integration decrees in the region, which was also viewed as giving legitimacy to the programmes already in place at regional level. However, while the report found that courses provide useful knowledge for understanding local society and navigating Belgian administrative structures, and beneficiaries are motivated to participate in such courses, it highlighted the need to better tailor courses to the needs and prior learning of beneficiaries. In particular, it recommended that the civic element of courses be provided in country of origin languages. The study also recommended that integration course operators take charge of costs for transport and childcare to ensure improved accessibility of programmes, and that programme funders adapt calls for funding to take into account the low number of

161 Belgian Chamber of Representatives, Bill laying down various provisions concerning civil law and amending the Judicial Code in order to promote alternative forms of dispute resolution, 5 February 2018, Parliamentary Document 542919/00, available at www.dekamer.be/FLWB/PDF/54/2919/54K2919001.pdf 
programmes available in rural regions. While the evaluation did not look in detail at the link between integration courses and the acquisition of nationality, the authors questioned the effectiveness of linking nationality requirements for individuals who have spent several years in Belgium with initiatives in place primarily for newly-arrived migrants (Gossiaux et al., 2019).

\subsubsection{Conclusions}

The past two decades involved a period of significant evolution of Belgium's citizenship laws, shifting from a relatively open regime with no integration requirements in the early 2000s, according to which access to nationality was considered to facilitate integration, to one with both a language and social integration requirement from 2013, which conditions citizenship on efforts to 'integrate'. This shift in approach is also mirrored in the introduction since 2017 of a requirement that migrants provide evidence of an effort to integrate in order to maintain their residence permit. The Walloon evaluation and NGOs have expressed concern that such measures place the obligation to integrate on the migrant alone and pose an obstacle to integration, contrary to the stated aim of facilitating integration (CIRÉ, 2017; Gossiaux et al., 2019).

Applicants for Belgian nationality have a number of options for satisfying both the social integration and language requirement. This chapter looked in detail at the link between the requirements and integration courses at regional level, which are offered free of charge to migrants and include an element of informationprovision, language training and civic education. This contrasts with the approach in most other Member States in which citizenship civic exams have become the norm.

Included in both is the option of completing an integration course led by one of the Communities, which are offered free of charge to migrants and include a social orientation and language component and individualised supports. The inclusion of integration courses in the civic and language requirements for the acquisition of nationality reflected an acknowledgement of parallel developments in the area of integration at the community level, with an express link made to courses already in place for recently arrived migrants.

Much complexity in the organisation of integration courses is linked to Belgium's federal system. However, it provides important lessons for the coordination of courses linked to residence or naturalisation requirements. Efforts by the various community authorities to harmonise the integration courses offered in the Brussels capital region demonstrate the need for a consistent approach to courses recognised for the purpose of acquiring citizenship, to ensure applicants 
undertaking courses organised by a diverse range of local organisations are treated on an equal basis in citizenship applications.

A number of challenges are highlighted by community organisations and the evaluation of courses, such as the costs required in accessing integration courses and the lack of provision for persons with low levels of literacy posing a barrier to acquiring citizenship. This underlines the necessity to ensure learning opportunities linked to citizenship are tailored to persons with different capabilities and needs. Where such learning opportunities are linked to citizenship, ensuring accessibility is particularly important in order to provide an equal basis for applying for naturalisation.

\subsection{CASE STUDY 2: FINLAND}

\subsubsection{Background}

Finland has seen a steady growth in inward migration since the 1990s, although overall flows are low by international standards. Just over 31,100 persons migrated to Finland in 2018 , up from 13,500 in $1990 .{ }^{162}$

Finland shares some similarities with Ireland; relatively small in population with an 'enabling' approach to integration (Goodman, 2010). The profile of the migrant population in Finland is, however, very different to that in Ireland. During 2015 the country experienced significant humanitarian-related migration, which was reflected in the 32,345 asylum applications made in that year - almost ten times the number made in 2014. ${ }^{163}$ Like in many EU countries, family-related migration dominates flows, representing 39 per cent of first residence permits issued in 2018. ${ }^{164}$ The labour market outcomes of certain migrant groups, notably women and the children of immigrants, are poor in international comparison (OECD, 2018c).

OECD notes that although the foreign-born population in Finland is relatively small, its growth has been amongst the fastest in the OECD. Accounting for just 1 per cent in 1990, the foreign-born made up almost 6.5 per cent of the Finnish population in 2016 (OECD, 2018c). The resident foreign-born population is diverse in origin, with migrants arriving mainly from Russia, Estonia, Sweden and Somalia. The number of migrants arriving from China, Iraq and Afghanistan increased during the 2000s (OECD, 2018c). Finland has two national languages, Finnish and Swedish, and in 1995 recognised Finnish sign language as a national language. Approximately 
4.9 million people speak Finnish as their first language, and more than 0.5 million people speak it as a second language. Finland has approximately 296,000 Swedishspeakers. ${ }^{165}$

\subsubsection{Naturalisation}

In Finland citizenship is usually acquired at birth and through the citizenship of a child's parents. It may also be granted by declaration or by application. This study focuses mainly on acquisition of citizenship by application as the primary method of naturalisation. The relevant legal provisions are contained in the Constitution, the Nationality Act 2003 and the 2013 Government Decree on Nationality (EMN Finland, 2020). ${ }^{166}$ In 2018, 9,610 persons were granted Finnish citizenship down from 12,600 in 2017 . The 2018 total was comprised of 8,640 grants by application and 970 by declaration. ${ }^{167}$ (Former) citizens of the Russian Federation $(1,799)$, Somalia (859), Iraq (623), Estonia (551) and Afghanistan (344) were the top recipients. ${ }^{168}$ Finland permits dual citizenship.

An applicant for Finnish citizenship must have five years of continuous residence, or seven accumulated years of residence with the last two years of residence 'uninterrupted'; demonstrate language skills (see below); have no convictions, restraining orders or outstanding debts such as child maintenance; and demonstrate a reliable income (Gozdecka, 2013). ${ }^{169}$

The 2003 Nationality Act was amended in 2011 and the minimum period of residence was shortened from six years of continuous residence. A provision was also introduced which meant that citizenship could be granted one year earlier (i.e. after four/six years) if an applicant met the language skills requirement, had strong ties with Finland and had their primary place of residence in Finland.

Commentators agree that the 2011 amendments were significant. They aimed to make the acquisition of citizenship more flexible and a way to support the integration of migrants. The government proposal which introduced the amendments stated that integration is a procedure which may continue after the acquisition of citizenship and even into the second or third generation. Some commentators considered this to be an important departure from the spirit of the 2003 Act, which emphasised citizenship as a reward for integration (Brander,

www.kotus.fi/en/on_language/languages_of_finland.

Nationality Act (359/2003), Government Decree on Nationality (293/2013).

Includes persons not living in Finland, but granted citizenship e.g. former Finnish citizens by declaration.

Information obtained from Finnish Immigration Service (Migri), March 2020.

Permanent residence permit holders must meet the same application requirements as all other applicants. Although people with a permanent residence permit hold many of the same rights as citizens, they are not required to prove their language competence. 
2011). Others identify the Finnish approach to naturalisation as one of 'enabling' integration, even before the 2011 amendments (Goodman, 2010). Gozdecka (2013) argues that with the 2011 amendment the government prioritised the language requirement over the residence requirement. The amendments were not controversial and were easily carried by a large majority (Brander, 2011).

EMN Finland (2020) also concludes that acquiring citizenship in Finland is an important step in the integration process, rather than the end goal of integration. However, it is interesting to note that naturalisation does not feature in current integration policy and is not mentioned in the Government Integration Programme for 2016-2019 (EMN Finland, 2020).

\subsubsection{Language requirements}

The Finnish naturalisation process incorporated evidence of language skills as early as 1920 by way of an oath of loyalty in the Finnish or Swedish language. Prior to 2003 the requirement was informal: applicants were asked to attach evidence of language abilities, which could be as casual as a letter from a teacher. There was no regulation of the required level of language skill or how it should be evaluated. ${ }^{170}$ The language requirement was formalised in the Nationality Act, 2003. The Finnish National Agency for Education (EDUFI), a body subordinate to the Ministry of Education, is responsible for the recognition of foreign qualifications and national certificates of language proficiency. ${ }^{171}$

Applicants must have completed the language test before applying for naturalisation. Naturalisation applicants must show at least satisfactory language skills in: oral and written Finnish; oral and written Swedish; Finnish sign language; or Swedish sign language used in Finland. The level of the minimum requirement corresponds to level B1 of the Common European Framework for Languages (CEFR) (EMN Finland, 2020).

Applicants are required to attach specified, acceptable certificates to their naturalisation application. The following wide range of school and language certificates are set down in the 2003 Act (as amended in 2011) as acceptable:

- National certificate of language proficiency (YKI) at level three (equivalent to level B1 of the CEFR), granted by the Finnish National Agency for Education.

- Civil service language proficiency certificate granted by the Finnish National Agency for Education. This certificate is part of a system designed to demonstrate civil servants' skills in an official language of Finland, which is not 
their native language. The certificates issued can also be used to demonstrate the skills required in order to obtain citizenship.

- Certificate of basic education showing a pass grade in Finnish or Swedish as native language or second language.

- Certificate of upper secondary education with Finnish or Swedish as native language or second language.

- Matriculation examination in Finnish or Swedish with a passing grade of the Finnish or Swedish language as native language or second language.

- Vocational upper secondary qualification, vocational or specialist vocational qualification taken in Finnish or Swedish.

- Completion of mandatory Finnish or Swedish courses in a university or polytechnic (EMN Finland, 2020).

The exhaustive list was introduced by the 2011 amendment of the Nationality Act, in order to minimise administrative discretion, to clarify the procedure for the applicant and to shorten processing times. The Finnish Immigration Service (Migri) reported that the changes quickly resulted in higher acceptance rates (Gozdecka, 2013).

\subsubsection{National certificate of language proficiency (YKI)}

Most applicants for Finnish citizenship take the National certificate of language proficiency (YKI) exam to demonstrate that they possess the required B1 level Finnish skills (YKI level 3). YKI is the Finnish representative of intermediate level language qualifications in ALTE (Association of Language Testers in Europe). ${ }^{172}$ The intermediate YKI test and the process of its implementation has been audited by ALTE three times, most recently in autumn 2019 (EMN Finland, 2020).

In order to be awarded the YKI certificate the candidate must sit four test components (speaking, writing, listening comprehension and reading comprehension). The full test may be sat in one day, or a combination of certificates may be submitted. The tests are the responsibility of the Finnish National Agency for Education (EDUFI) and the Finnish immigration Service is not involved. The Centre for Applied Language Studies administers the YKI tests along with the Finnish National Agency for Education. Applicants may select a test centre, register online and pay the relevant fee: $€ 123$ for intermediate and $€ 160$ for advanced level. Participants with special needs take the same test as others and if necessary special arrangements are made. ${ }^{173}$

\footnotetext{
172 The activities of ALTE include helping its members to develop the quality degree of their tests, and it also audits the tests of its members. See www.alte.org.

173 www.oph.fi/en/education-and-qualifications/register-national-language-proficiency-test-yki
} 


\subsubsection{Multiple languages}

Applicants may take the test in oral and written Finnish; oral and written Swedish; Finnish sign language; or Swedish sign language used in Finland. Finland recognises sign language in its constitution and is the only country that provides that an applicant for naturalisation can satisfy language requirements through sign language. The Sign Language Act 2015 obliges authorities to promote sign language usage. The Act applies to both the Finnish sign language and the Finnish-Swedish sign language (discussed further below). ${ }^{174}$ Before 2011, applicants were required to show skills in oral and written Finnish or Swedish. Since 2011 if the applicant shows skills in the Finnish or Finnish-Swedish sign language they do not need to show written skills. This change was in recognition of the fact that it was unreasonable to ask applicants to learn two languages. ${ }^{175}$

In order to ensure the Swedish YKI test is of equivalent standard to the Finnish test, its preparation and implementation are the same. The same preparation guidelines are used for all YKI tests, and they are all based on skill descriptors linked to the European framework. This means that the tests in different languages are, in principle, comparable to each other. Only the Finnish YKI test is a member of ALTE, therefore no international audit has been performed on the Swedish test. ${ }^{176}$ The Finnish Immigration Service expressed the view that results indicate that the Finnish and Swedish tests are similar. ${ }^{177}$

\subsubsection{Exemptions and special arrangements}

Deaf applicants' sign language skills are assessed through an interview in Finnish or Finland-Swedish Sign Language with the Finnish Association of the Deaf, ${ }^{178}$ which also provides sign language training and advice for deaf migrants. ${ }^{179}$ This has been highlighted by the Academic Network of European Disability Experts as an example of good practice (Waddington, 2013).

According to the 2003 Act as amended, exemptions to the language skills requirement can be granted if an applicant: is over 65 years old; has health problems that prevent him/her from acquiring the required language skills; has arrived in Finland as an adult and is illiterate (unable to read and write); or gives an otherwise special reason for granting an exception. ${ }^{180}$ Certain applicants with refugee or humanitarian status may be exempted and the language level may be reduced in specific circumstances (Gozdecka, 2013).

\footnotetext{
https://oikeusministerio.fi/en/sign-language Information obtained from Finnish Immigration Service (Migri), March 2020. Ibid.

Ibid.

Finnish Immigration Service, 'Finnish Citizenship', https://migri.fi/en/language-skills.

See: Association of the Deaf, https://kuurojenliitto.fi/

Information obtained from Finnish Immigration Service (Migri), March 2020.
} 
If a request for an exemption is declined the application fee is forfeited. ${ }^{181}$ The Finnish Immigration Service stated that applications for an exemption are assessed individually, taking into account all the information held by the immigration service about the person (e.g. information relating to health and literacy submitted with previous residence permit applications), and granted infrequently. During 2019 approximately 10,700 naturalisation applicants were required to meet the language requirement and 200 were granted an exemption (1.9 per cent). ${ }^{182}$

Applicants with special needs take the same test as other participants, but may request special arrangements for sitting the test by sending a form to the test centre and supporting documentation to a university centre. ${ }^{183}$

\subsubsection{Supports available}

The website kotisuomessa.fi, maintained by the Finnish National Agency for Education, is designed to support self-study in the Finnish language. Resources on the website are based on the YKI themes and situations of language use. ${ }^{184}$

In the 1990s language courses available as part of PES supplied labour market training were very oversubscribed and waiting times could extend to several years. In 2016 the Finnish government published an action plan on integration, with a view to moving migrants into education and employment. The Plan aimed the integration of language learning with other activities (OECD, 2018c). Free language education is available for registered unemployed migrants who are entitled to an integration plan supported by the State. The integration training provided by the PES is full-time for up to 60 study weeks, on average $35 \mathrm{hrs}$ per week combining classroom studies, independent/online or distance studies, guidance and training. The target language level of the integration training is B1.1. A national core curriculum for integration dictates the content of the courses, combining themes of e.g. history, politics, society and the labour market (including a work placement). Participation is mandatory, otherwise benefits may be curtailed. Individuals must regularly attend a Finnish or Swedish course if this is part of their plan. Students receive a certificate on completion of the integration programme, including an evaluation of language proficiency. ${ }^{185}$ Intensive orientation can be organised as an introduction to integration training in the migrants' own mother-tongue and can

\footnotetext{
181 https://migri.fi/en/exceptions-to-the-language-skills-requirement.

182 Information obtained from Finnish Immigration Service (Migri), March 2020.

183 'Register for a national language proficiency test (YKI)'. Available at www.oph.fi/en/education-andqualifications/register-national-language-proficiency-test-yki. Accessed June 2020.

184 Information obtained from Finnish Immigration Service (Migri), March 2020.

185 EMN Ad hoc query no. 2019.15, Early language support. Available at https://ec.europa.eu/home-affairs/what-wedo/networks/european_migration_network_en
} 
include e.g. literacy training in the Roman alphabet, social orientation; visits to educational institutions, workplaces and municipal services.

Migrants who find the full-time training too intensive (e.g. people with a limited educational background or with small children) may be offered part-time study combined with childcare.

Municipalities can also refer migrants who are not seeking work at the time of their arrival to public integration/language training services or to other providers. e.g. adult education centres, which offer flexible and part-time options for language and integration training. ${ }^{186}$

A wide range of public and private actors provide Finnish and Swedish language courses. (Gozdecka, 2013).

\subsubsection{Language requirements: Policy objectives and results}

The objectives for formalising the language requirement were set out in the government proposals, where it was stated that language skills enable independent participation in Finnish society and that placing the requirement in law will help to ensure individuals are willing to learn the language. ${ }^{187}$ In comments supplied for the current study, the Finnish Immigration Service noted that naturalisation means the Finnish State accepts an immigrant as a full member of society, and that membership carries rights and obligations. In that context, the ability to speak Finnish or Swedish is seen as necessary in order for a migrant to function independently and fully realise those rights and obligations. Language competence is considered to be an important part of integration, particularly encouraging labour market integration and improving the integration of secondgeneration migrants.

A government proposal from 2010 set out the position that if parents have language skills, they can become more involved in a child's social activities, also that children are relieved of interpretation duties. ${ }^{188}$ By attending classes, vulnerable and/or isolated groups may increase social contacts and skills. No official evaluations have been undertaken of the language requirement related to 
naturalisation. ${ }^{189}$ However, the University of Jyväskylä's Centre for Applied Language Studies has concluded that the precise impact of testing on languagelearning remains unclear, recognising that testing shapes what is taught and what people will want to learn (EMN Finland, 2020).

The Finnish Immigration Service observed that the majority of applicants meet the language requirement, but that this may be more challenging for migrants who arrive post-school age. During 2019 approximately 10,700 naturalisation applicants were required to meet the language requirement. Approximately 8,800 succeeded (82.2 per cent) and 400 failed (3.7 per cent). ${ }^{190}$ EMN Finland (2020) commented that, typically, inadequate language skills are the most commonly cited reason for rejection of applications for citizenship.

In Finland, an unsuccessful applicant may appeal against a negative application decision from the Finnish Immigration Service to an Administrative Court. The time for the appeal is 30 days from receiving a negative decision. The Finnish Immigration Service stated that appeals against negative decisions are very frequent. ${ }^{191}$

\subsubsection{Challenges}

The language skills requirement adopted in the 2003 Nationality Act is more difficult than under earlier legislation (Brander, 2011). The Finnish Immigration Service observed that the language requirement can pose challenges for particular groups including those with little or no education and those who have spent long periods outside the labour market, for example stay at home mothers. There have been instances of false certificates of language proficiency being submitted. ${ }^{192}$

No information was found on the cost to the State of implementing the requirements.

\subsubsection{Civics requirements}

Finland does not have a civics requirement attached to naturalisation currently. The introduction of citizenship tests concerning fundamental rules of society, values and attitudes is currently being considered (EMN Finland, 2020).

189 Information obtained from Finnish Immigration Service (Migri), March 2020.

190 The balance is accounted for by co-applicants, for whom an exemption is automatic. Information obtained from Finnish Immigration Service (Migri), March 2020.

191 Information obtained from Finnish Immigration Service (Migri), March 2020.

192 Ibid. 


\subsubsection{Conclusions}

Finnish policymakers draw a clear connection between language skills and improved integration outcomes and believe that placing the requirement in law will help to ensure individuals will be willing to learn the language. Language skills are viewed as necessary to allow naturalised immigrants and their children to fulfil the rights and obligations inherent in citizenship. In recent years, Finland has sought to formalise the language requirement for naturalisation applicants, which dates back to the early twentieth century. The Finnish Migration Service reported that the changes introduced by the 2011 amendment of the Nationality Act were introduced in order to minimise administrative discretion, to clarify the procedure for the applicant and to shorten processing times and that they quickly resulted in higher acceptance rates (Gozdecka, 2013). There are multiple options for meeting the language requirement but the most popular is the National certificate of language proficiency (YKI), granted by the Finnish National Agency for Education, (EDUFI) under the auspices of the Ministry of Education. There have been no evaluations undertaken of the language requirement in itself and whether it results in improved integration outcomes. Finland's migration flows, although increasing, are low by international standards. The country has faced a severe and long recession in the past decade and integration has not been a high priority. The labour market outcomes of certain groups, particularly women and the children of immigrants, are poor in international comparison (OECD, 2018c). Integration plans with language supports are available to unemployed migrants only. The significant humanitarian flows received since 2015 in particular have resulted in increased attention being paid to integration (OECD, 2018c). Since the publication of the 2016 action plan on integration, Finland has moved to integrate language learning with other activities such as orientation and employment placements. Applicants may take the test in oral and written Finnish; oral and written Swedish; Finnish sign language; or Swedish sign language used in Finland. The provision for sign-language is progressive and unusual in an international context.

\subsection{CASE STUDY 3: PORTUGAL}

\subsubsection{Migration context}

Immigration to Portugal is a relatively recent phenomenon which gained importance in the mid-1970s. Previously, Portugal was a country of emigration, characterised by intercontinental flows before World War II and migration to other European countries post-war. The shift in migration patterns was a result of major political change, as well as the end of the colonisation era. Migration from the former colonies such as Cape Verde, Angola and Guinea Bissau drove the significant increase. On entering the $\mathrm{EU}$, a new phase of increased immigration could be observed, especially from Brazil. In the late 1990s - and similar to the trend in Ireland - immigration flows significantly increased, particularly from Eastern Europe. Since the beginning of the new century, immigrants from Brazil 
have made up the majority of immigration flows as the numbers of migrants from Eastern Europe declined and the numbers of Asian and African migrants stabilised. While in 1995, foreign-born nationals constituted 1.7 per cent of the Portuguese population which was low in international comparison, in 2018 this share had increased to 8.7 per cent (OECD, 1997; 2019).

As mentioned by Cook (2018), until the 1990s the focus lay on migration management and, as such, very little attention was paid to integration in terms of policy response.

\subsubsection{Citizenship regulations}

Until 1981, the Portuguese legal system put a strong emphasis on the ius soli principle, and since that reform the system has shifted towards the ius sanguinis principle. ${ }^{193}$ The Portuguese Nationality Law introduced in 1981 was a result of many processes, including decolonisation and the outflow of Portuguese migrants in the 1960s. With respect to the diaspora, the reform meant that children born abroad to Portuguese parents were citizens of this country on the one hand and demonstrated the willingness to move towards regulations existing in other European countries on the other. As mentioned, the majority of immigrants were from former colonies and spoke Portuguese. As a result, they were seen to integrate more easily in the labour market, gaining employment despite the fact that many were irregular migrants (Fonseca et al., 2002). However, growing immigration combined with the decision to join the Schengen area led to a number of reforms including a number of regularisations of third-country nationals.

In 2006, with the Organic Law 2/2006 amending the Portuguese Nationality Law of 1981, a major reform to the citizenship law was enacted, and testing for the purpose of obtaining Portuguese citizenship was outlined. The 2006 Reform maintained the ius sanguinis principle, however new ways of acquiring citizenship through ius soli became possible. The Organic Law 2/2006 and subsequent laws regulate the requirements pertaining to the language tests and other forms of proving language knowledge (Gil and Piçarra, 2020). It is important to emphasise that the majority of potential applicants had a command of Portuguese already (68.8 per cent in 2018) (Oliveira and Gomes, 2019). Therefore, according to the country expert consulted for the report, the 2006 reform and subsequent changes with respect to language requirements should not be seen as a way of countering increases in naturalisation numbers. ${ }^{194}$ 
Since 2006 there are two ways to acquire citizenship by naturalisation; a discretionary decision of the Minister of Justice, or meeting legally stipulated criteria. The reform of 2006 significantly increased the number of naturalisations, especially vis-à-vis acquisition of citizenship via marriage which lies outside the naturalisation process in Portugal. Accordingly, and in the period 1985-1996, 94 per cent of new citizenship acquisitions were based on marriage; in the period 1996-2006, approximately 70 per cent of acquisitions were based on marriage. After the 2006 reform, the proportions changed; between 2007 and 2016 only 27.5 per cent of citizenship acquisitions were based on marriage while the majority were on the basis of naturalisation. This change in proportions was driven by a significant increase (almost four-fold) of naturalisations between 2007 and 2008 (from 4,846 cases to 19,021 cases). A year later (2009), the number of naturalisations increased to 22,874 cases (Oliveira et al., 2017).

The countries from which citizenship applicants originated after 2006 were mostly Cape Verde and Brazil, and only recently Ukraine, Romania and India became important countries of origin. This means that in recent years a growing (although far from dominant) share of applicants do not come from countries where Portuguese is an official language.

A phenomenon specific to Portugal is the so-called 'quasi-citizenship' status which concerns individuals coming from Portuguese-speaking, or 'Lusophone', countries. Here, the knowledge of Portuguese is inferred from the status of a former Portuguese colony. In the process of decolonisation, the citizens of Lusophone countries were granted a privileged status (so-called Lusophone status of citizenship) in Portugal which gave them some political rights. ${ }^{195}$ The number of quasi-citizens was on the rise from 1985 (31,763 persons) to 2009 (165,065 persons) since then it has been fluctuating. In 1985, a peak in the share of quasicitizens in the total foreign-born population was noted (40 per cent), currently it constitutes less than one-third (30 per cent) (Gil and Piçarra, 2020).

Permanent residence status is not required to gain Portuguese citizenship. Further, recently the period of stay (of any type but illegal) required for obtaining citizenship was reduced from six to five years.

195 The legal basis of this status was the 1971 bilateral agreement between Portugal and Brazil (Convention of Equal Rights and Obligation between Portugal and Brazil). The legal framework was strengthened in 2000, when the two states signed a treaty of friendship as well as in 2001, when an amendment to the Constitution was made. The amendment opened the possibility to confer broad citizenship rights on citizens of the Lusophone countries given the reciprocity of such arrangements. The rights include voting and active suffrage as well as a right to become a judge or a police officer. Currently, such bilateral acknowledgment of rights is valid for Brazil only (Gil and Piçarra, 2020). 


\subsubsection{Language requirement for the purpose of obtaining citizenship ${ }^{196}$}

Currently, Portugal requires applicants for naturalisation to produce proof of language knowledge at A2 level of the CEFR. However, citizens of countries where Portuguese is an official language are waived from this requirement. The 2018 Amendment to the Nationality Act stipulates that any individual born in, or having the nationality of, a country with Portuguese as an official language is waived from the language requirement. Previously on the basis of a 2017 amendment, the main criterion for the waiver was being born or being a national of a state in which, for at least the last ten years, Portuguese is an official language. Applicants who meet this condition and were resident in Portugal for five years are waived from the language requirement. This means that a big share of citizenship applicants is waived of the language requirement, as they originate from states with Portuguese as an official language or they were born in Portugal.

The roots of the language requirement go back to the late 1950s (1959 Nationality Act). Therefore, as the country expert indicates, the language requirement has been present for several decades, and what has changed is the manner in which the knowledge is proven. The main assumption behind the introduction of the language requirement in the 1950s was that sufficient knowledge of Portuguese could act as a proxy for the extent to which someone belongs to the national community. Such logic can be inferred from the situations when this requirement was waived, for example in the case of a marriage to a Portuguese person or when an individual rendered a service to the State.

The 1960 Nationality Regulation stipulated three ways of assessing the knowledge of Portuguese. First, it could be a certificate from an educational institution. Second, a public administration (municipality) could issue a relevant certificate. Finally, it could be a public official, stating in writing that a person had a sufficient command of Portuguese.

The main legal regulation underpinning the language requirement goes back to 2006, when testing for the purpose of obtaining Portuguese citizenship was outlined. The 2006 reform reduced discretion in assessment by introducing tests and specifying certificates to prove proficiency (discussed below). The language requirement system in its current form was shaped in 2013. 
There are several ways by which the knowledge of sufficient Portuguese can be demonstrated. ${ }^{197}$ The test of language proficiency is based on the CAPLE (Centre for Evaluation of Portuguese as a Foreign Language) framework which is a certification of knowledge of Portuguese as a foreign language but also by IAVE (Institute for Educational Assessment). CAPLE is hosted at the University of Lisbon and is responsible for issuing certificates and designing language tests. Such tests can be used locally by other organisations. While language tests can be organised by a number of bodies, CEPLE (Portuguese as a Foreign Language Examination Centre) is the most popular. The test which is relevant for the naturalisation purposes is the CIPLE - the exam is at the A2 level CEFR. It can be taken in Portugal and 34 other countries (in embassies or universities). The test consists of four parts: reading, writing, listening and oral. It takes approximately 80-85 minutes. The tests abroad take place in May, July and November, whereas in Lisbon they take place in February, August, September and October. It is only possible to take one test per year. Other important testing facilities are located in the Polytechnic Institute of Leiria and at the Nova University of Lisbon.

Parallel to the CAPLE system and CEPLE facility, the Institute for Educational Assessment (IAVE) also operates, in principle, with exactly the same scope as CAPLE (testing and certification). In the past most of the testing for the purpose of naturalisation took place at IAVE as it was treated as the default option by the Immigration and Borders Office and the Civil Registration Offices.

The tests are also required from children born in Portugal whose parents are migrants. ${ }^{198}$ The regulations state that the test should be adjusted to the needs of children or illiterate adults.

The number of individuals taking language tests for naturalisation declined recently following the 2017 change in the Nationality Regulation which waives nationals or individuals born in Lusophone countries from the language proof. On the other hand, an increase in applicants from Nepal and Bangladesh has been noted.

197 Per Article 25 of the Nationality Regulation in force (as amended in 2013), language knowledge can be proved by the following means: (a) diploma issued by a public, private or cooperative educational institution recognised by law, provided that its holder passed the course of Portuguese language in at least two academic years; (b) certificate of approval on a Portuguese language test done at educational institutions of the public network, when done in Portuguese territory, or at places accredited by the Camões Institute when done abroad (for applicants over 18 years of age); (c) certificate of Portuguese as a Foreign Language, issued pursuant to a test done at an evaluation centre for Portuguese as a Foreign Language, recognised as such by the Ministry of Education and Science; (d) qualification certificate attesting completion of $\mathrm{A} 2$ level or higher, issued by public educational institutions, training and employment centres, and centres with protocols with the Institute for Employment and Professional Training (IEFP). Apart from the language requirement, they need to fulfil the criteria regarding clear criminal record and lack of threat to state security. Further, they need to meet one of the two criteria: one of the parents must have stayed in Portugal for at least five years (irrespective of the legality of stay) or must have completed at least one cycle of primary or secondary education. 
The fee for the CIPLE test is $€ 72$ and 30 per cent of this amount is transferred to LAPE (testing facility). The CEPLE uses the infrastructure and staff of University of Lisbon to run the tests. The staff running the tests as well as evaluating them are employed on ad hoc basis for this purpose.

As stated by the country expert, the issue of language testing for the purpose of naturalisation is not an important political topic. This phenomenon can be explained by two factors. First, the general perception of migration processes in Portugal is that this is still a sending country, and therefore integration through naturalisation is low in priority. Second, immigration to Portugal has been predominantly by Portuguese-speaking individuals. Up to recently a majority of applicants have not been required to produce any proof of language proficiency as their nationality of origin is the proof by default.

\subsubsection{Exemptions from the language requirement}

There are limited exemptions from the language requirement other than coming from a country with Portuguese as an official language. Currently the only reason for waiving the requirement automatically is in a situation where a person had lost Portuguese citizenship but has not acquired another one. The reasons for waiving the requirement stipulated in the 1981 law (for individuals who were considered as descendants from Portuguese, the members of communities of Portuguese descent and migrants who had rendered or who were called to render high services to the Portuguese State) are applied on discretionary basis.

Also, descendants of Sephardic Jews originating from Portugal are exempt from this requirement since 2013.

Furthermore, for children who have completed the first cycle of basic education in an educational institution with a Portuguese curriculum, the knowledge of the Portuguese language can be proved by a statement issued by that educational institution. For individuals with serious health problems or a disability duly attested by a medical statement issued in accordance with Portuguese law, and for individuals who are 60 or over who do not know how to read or write, the evidence of language knowledge must be appropriate to their capacity to show their knowledge of the language. For those who attended a public, private or cooperative educational institution recognised by law in a Portuguese speaking country, proof of language knowledge can be made by a diploma issued by that institution. 
In a situation when an applicant is not able to demonstrate the knowledge of Portuguese and is not entitled to waive this condition, the naturalisation application is rejected. Cases of applicants rejected based on the language requirement ground were not identified by the country expert consulted for this study.

\subsubsection{State support for applicants without prior knowledge of Portuguese}

The State offers two types of Portuguese language courses. Both are free to participants. Courses are also available for children in education, however these are not discussed here as they are not linked to naturalisation directly). The PPT Programme - Portuguese for All - targets immigrants who want to achieve the A2 level required by law to receive permanent residence or citizenship by naturalisation. It receives co-financing from the European Social Fund and is operated by High Commission for Migration (ACM). Graduating from this course at A2 level is sufficient proof of knowledge of Portuguese for the purpose of naturalisation. The PPT courses last 150 hours. There is also an additional educational strand in the PPT which deals with preparation for use of Portuguese in a professional context.

Approximately half of participants in the PPT courses receive a certificate. While in 2008 the PPT had 3,385 participants and 939 graduates, it saw a rapid increase in numbers; in 2012 there were 10,982 participants and 5,131 graduates with certificates. In the following years a decline took place followed by a subsequent recovery, as the most recent data show 11,390 participants and 5,334 certificates issued in 2017. One year later, the respective values were 10,361 and 5,437. As for the socio-economic profile of PPT participants in 2018; 58.6 per cent of participants were men and 39.9 per cent were from Lisbon region. While no recent data are available, in 2011 the dominant highest educational attainment was secondary education (43.4 per cent of participants) and the most frequent age group was 45+ (30.1 per cent) (Oliveira and Gomes, 2019).

\subsubsection{Evaluations, results and challenges}

When it comes to the data on testing, they do not exist in a processed form. The most recent data referring to the tests organised in December 2019 indicate that 72 individuals sat the language test in writing, of which 71 passed the exam. According to the data provided by the Portuguese expert, 98 per cent of language test taken at IAVE are CIPLE (however, these tests serve other purposes as well). The estimated pass rate is approximately $80-85$ per cent.

No major challenges have been identified. However, as the expert emphasised, some LAPE (testing facilities) face difficulties due to financial constraints. Perhaps 
a major challenge for the future is the increase in the share of applicants originating from non-Lusophone countries. This might mean that both the preparatory courses and the certification system will be increasingly used.

\subsubsection{Conclusions}

As in the other case studies, the language requirement for the purpose of naturalisation present in Portugal is closely related to its migration context. The introduction of the language requirement dates back to the early post-World War II period; however, the modern version of language requirements was introduced in 2006.

It is possible to prove knowledge of Portuguese in many ways; it can be done by means of tests, diplomas of educational institutions, or accredited language courses. The language testing in Portugal is based on the already existing infrastructure; a network of testing centres in Portugal (but also abroad) which use centrally developed exams. Such multiplicity of ways of proving the knowledge of Portuguese are accompanied by extensive exemptions applying to individuals who originate from Portuguese-speaking countries.

An important feature of the Portuguese citizenship application is the presence of free, accessible language courses - Portuguese for All. Graduating from the course is accepted as proof of a language level sufficient for citizenship.

The specificity of Portugal lies in its links with Portuguese-speaking countries. As many migrants originate from these countries, the language requirements accommodate this. Nonetheless, two features seem to contribute to a relatively smooth operation of such system which make it a very relevant case for countries considering implementation of language requirements. First, there is more than one way of demonstrating language proficiency. Second, there is the support course, which is tailored specifically to the needs of citizenship applicants.

\subsection{CASE STUDY 4: UK}

\subsubsection{Migration context}

For several decades before 1990, immigration flows in the UK were characterised by immigration of Commonwealth citizens. In the post-World War II period, the immigration system differentiated between two broad categories: Commonwealth citizens and 'aliens'. While the 1948 Nationality Act made a distinction between citizens of the United Kingdom and colonies and other citizens of the Commonwealth, the latter retained the right to enter British territory. The 
Commonwealth Immigrants Act 1962 extended immigration controls to individuals with Commonwealth citizenship who could not prove their links with the UK (with the main criterion being born in the UK, ownership of a passport issued by the UK government or an Irish passport, or being a relative of such person) and introduced work vouchers as a means to control migration flows. As the Act waived such conditions from persons already residing in the UK between 1960 and 1962 and their families, it contributed to the permanent settlement of a large number of individuals. The Citizenship Immigration Act 1968 further limited the categories who were excluded from immigration control. It was followed by regulatory reform which took place in 1971 (The Immigration Act, 1971) which defined the right to abode. The British Nationality Act 1981, described below, fundamentally reshuffled British citizenship policy by introducing three categories of Citizenship of the United Kingdom and Colonies.

Prior to the 1990s, the United Kingdom was a country with mainly negative net migration. However, since 1994, the United Kingdom has noted positive net migration, and since 1998 net migration exceeded 100,000 annually. While in 1995, the foreign-born population constituted 3.4 per cent of the total population, this increased to 13.8 per cent in 2018 (OECD, 2019; 1997). The 2004 EU enlargement significantly altered the structure of the foreign-born population; Poles constitute the second biggest foreign-born nationality ( 8 per cent), just after Indian ( 9 per cent) and followed by Pakistani (5 per cent).

Since 2004, migration in the UK has been predominantly related to work and formal study. Migration for the purpose of work reached a peak in 2016 and since then has declined. In 2019 the share of migrants who arrived in the UK for the purpose of study (36 per cent) exceeded the share of those who arrived for the purpose of work. It is non-EU nationals who have contributed most to the migration flows in the UK (Sturge, 2020).

\subsubsection{Citizenship regulations}

For several decades citizenship/nationality policy and migration policy in the United Kingdom have been interwoven. The main reason for this is the relations with former colony countries. The 1948 Nationality Act was aimed at providing uniform citizenship across the British empire jurisdictions by introducing Citizenship of the United Kingdom and Colonies (CUKC). It was a response to the reforms in other Commonwealth countries (Canada in 1946) that introduced a citizenship status independent from that of the British subject. The CUKC gave access to the UK's land without major obstacles. As mentioned above, the access of Commonwealth citizens in the UK has been gradually restricted. 
British citizenship was clearly defined in another piece of landmark legislation: the British Nationality Act 1981. In practice, this legislation meant a change from the ius soli to the ius sanguinis principle and is seen as a foundation for understanding modern British citizenship regime. The 1981 reform was seen to reduce the naturalisation of individuals coming from the 'new' Commonwealth countries (India, Pakistan). Those with links to the UK were granted British citizenship, while others were granted British Dependent Territories Citizenship or British Overseas Citizenship (Bassel et al., 2017). The British Nationality Act 1981 thus replaced the CUKC by introducing the citizenship categories mentioned above. British Dependent Territories Citizenship was a subject to another primary legislation, the British Overseas Territories Act 2002. This legislation renamed this status to British Overseas Territories and automatically granted British citizenship to its holders immediately prior to 21 May 2002.

\subsubsection{History of the requirements for the purpose of naturalisation in the United Kingdom}

As noted by van Oers (van Oers, 2014), the language knowledge requirement for the purpose of naturalisation occurred for the first time in the British legislation in 1914.

The British Nationality Act of 1981 repeated the requirement of sufficient language knowledge. The 1981 British Nationality Act stipulated that naturalisation applicants must demonstrate knowledge of the English, Welsh or Scottish Gaelic language. In practice, oral language skills only were assessed. Proof of the language level was deemed sufficient if a person could fill in a citizenship application form. The knowledge of language was assessed by a police officer or other official, and it was a highly discretionary process (van Oers, 2014). Knowledge of the language was reportedly not a major barrier to attaining British citizenship and was seen as one among many requirements to meet (Puzzo, 2016). In 1982, 2.7 per cent of all naturalisation applications were denied citizenship on the basis of the language requirement and this percentage decreased to 0.15 per cent in 1996 (van Oers, 2014).

The discussion on naturalisation requirements gained impetus particularly following riots that took place in 2001 in Oldham, Bradford and Burnley. One of the problems detected in the reports commissioned after these events was the lack of social cohesion in multi-racial communities. Further, the self-segregation based on the insufficient knowledge of English was presented as a major obstacle. The government's proposed solution to this problem was to put more emphasis on the English language and other elements of community-building and citizenship (Ritchie, 2001). 
In 2002, Tony Blair's Labour government issued a White Paper outlining the response entitled Secure Borders, Safe Haven: Integration with Diversity in Modern Britain (Home Office, 2002). The report set out a more thorough language assessment for naturalisation (language tests) and some ('light touch') civic education. The language training would be provided based on the existing ESOL network of education providers. Such requirements combined with a designated support were not seen as restrictions to naturalisation by the government.

A representative of the UK Home Office consulted for this study ${ }^{199}$ stated that, in these reports, special consideration was given to the sense of belonging to the community. An important aspect was that those applying for British citizenship should demonstrate progress towards a defined target - this is where courses and other tools were considered to be important as a means to achieve progress. An important part of this process was the provision of the handbook Life in the UK which was seen as a channel to provide knowledge to immigrants. In general, the standardised tests are seen by policymakers as a means for assessing progress in language skills towards integration.

In the parliamentary discussions, an assurance was given by the government that the courses offered to prepare for the English language tests (ESOL entry level 3) would be funded from the State budget. This, however, did not happen. Similarly, the issue regarding childcare available for parents who would like to participate in the course was unresolved. Finally, the issue of course providers remained - it was expected that the Further Education colleges would have taken this role (van Oers, 2014).

The Nationality, Immigration and Asylum Act of 2002 specified the requirement of knowledge of English, Welsh or Scottish Gaelic and created an obligation to complete the Life in the UK test. The operational side of the latter requirement was underpinned by the Nationality, Immigration and Asylum Act of 2002, implemented in 2005, which stipulated two alternative paths. The first one entailed demonstrating sufficient knowledge of English by producing a language certificate and passing the Life in the UK test. The second option was to participate in the ESOL courses that included a 'civic' component. Graduating from such a course would attest the knowledge of both the language and Life in the UK. In the period 2005-2008, the pass rate of the test was around 70 per cent. The requirement to pass the test was extended to long term-residence (Indefinite Leave to Remain - ILR) in 2007. 
The 2002 reform was subject to wide consultations with several stakeholders, including migrant organisations. As a result, a number of topics related to the introduction of the requirements was identified (Home Office, 2003). The stakeholders expressed support for early and free language teaching and support for citizenship content related to practical aspects. However, a number of concerns were expressed. These included concerns that a test may deter applicants from naturalisation, an over-emphasis on history and 'Britishness', insufficient support for teachers and the need for a wider coordination of integration policy. While only one organisation opposed the idea of testing, the fear that the discussion regarding the naturalisation requirements might fuel anti-immigrant voices was more widespread (ibid.).

In 2009, in turn, the Borders, Citizenship and Immigration Act was introduced, which strengthened the 'deservingness' ('citizenship must be earned') aspect of citizenship, by extending the residence period necessary for naturalisation from five to eight years. Soon after the introduction of the law, the government proposed to make it stricter in a consultation document Earning the Right to Stay: A New Points Test for Citizenship (Home Office, 2009). One of the main ideas was to regulate the number of individuals residing in the UK on a permanent basis. To do so, the paper proposed two tests; one at a 'probationary' citizenship stage and then at the moment of application for 'regular' citizenship. The probationary citizenship test would focus on 'practical' aspects, whereas the citizenship test would cover related to political system, relations with Europe etc. (Puzzo, 2016).

The reform introducing probationary citizenship was abandoned by the next, Conservative party-led government before it was even introduced, as it was found to be difficult to implement as well as 'ineffective' (Puzzo, 2016). Also, the proposal for points-based citizenship was disregarded.

In 2012, the UK government announced further changes to the Life in the UK test: questions regarding practical information (such as applying for benefits, reading water meters or registering with a GP) were removed and replaced by questions that provided more extensive testing of UK history. While the history section has been present in the associated handbook since its first edition (2004), it had not been tested until 2013. The change provoked a number of mixed comments, ranging from positive voices (also from the immigrant NGOs), to criticism that the test placed too high an expectation on applicants as well as a specific notion of Britishness (Byrne, 2017). 
The reform of the Knowledge of Life in the UK ${ }^{200}$ test has been implemented since 25 March 2013. In April 2013 the British government announced that every applicant (except those exempted) will have to provide a certificate of knowledge of English (B1 level) from October 2013. This meant that the previous 'double route' system - taking a course leading to expected language skills or taking the ESOL test - combined with the Knowledge of Life in the UK test, was abandoned. Since October 2013, the naturalisation application requires a separate language test certificate and fulfilment of the Knowledge of Life condition.

\subsubsection{Language test requirement in its current form}

Since November 2015, the only accepted tests are provided by the organisations included in the Secure English Language Test (SELT) list. In terms of language proficiency, the required level of language knowledge is at the B1 level. SELT services are procured by the Home Office's United Kingdom Visas and Immigration division and, among broader categories of visa and immigration applicants, they are used for the purpose of language testing related to naturalisation. Successful participant organisations in a bid organised by the Home Office are included in the list of providers. It should be mentioned, nonetheless, that the status of Welsh and Scottish Gaelic is not clear since 2013 reforms (Mac Síthigh, 2018).

The country expert indicated that it was necessary to restrict test operators as a result of fraud and cheating. In case of naturalisation applicants who provide proof of language knowledge at the B1 level during their Indefinite Leave to Remain (ILR) application (regardless of whether an organisation is on the current SELT list), they are considered to already meet the language requirement. Only results from tests which took place less than two years before application are considered. However, this time limit does not apply to results of tests taken for a successful ILR application. The test takes ten minutes and involves a discussion on a topic prepared before the test as well as conversation with the examiner. The fee for the ESOL test is $f 150$ in the United Kingdom. The fees for tests taken abroad are higher.

Graduating with a degree that was taught or researched in English or being a national of a majority English-speaking country also meets the requirement of the language knowledge. When it comes to the degrees which waive the language part of the KOLL, the degree needs to be taught or researched in English, it must be academic - BA, MA or a PhD (and thus neither vocational nor professional), it has to be recognised by British authorities, and delivered in English or in a majority English-speaking country (excluding Canada). In the case of a diploma issued in a non-majority English-speaking country, apart from the requirements listed above, 
the confirmation that a degree was taught in English (English Language Proficiency Statement (ELPS)) is necessary.

\subsubsection{Knowledge of Life in the UK requirement}

A second component of the KOLL is the Life in the UK test. As mentioned above, the contents of this test were changed in 2013. The tests are based on the official handbook and, therefore, only the knowledge included in the handbook is tested. One can sit the Life in the UK test only in United Kingdom, Channel Islands and Isle of Man. There is an option to take the test overseas, but this applies only to armed forces personnel and their dependants (two current locations are Cyprus and Germany).

The test is computer-based, it consists of 24 multiple choice questions and takes 45 minutes. The tests are operated by a private company, PSI. The fee for the Knowledge of Life in the UK is $f 50$.

Currently, both the ILR and citizenship naturalisation applications require sitting KOLL. However, the scope of exemptions is significantly bigger in the case of the ILR. When it comes to the exemptions in case of the KOLL, they concern age (if an applicant reached 65 years of age or is 60-64 years old with no prospects to reach a requested level until 65), and mental and physical condition. It should be mentioned that, given the different scope of exemptions, being waived of the requirement during the ILR stage does not mean automatic follow-up exemption at the naturalisation stage.

\subsubsection{Data and evaluations}

The Life in the UK pass rate was 72.1 per cent between 2005 and 2010. The highest pass rates were observed among individuals from the United States ( 97.5 per cent), Canada (96.9 per cent) and Poland (87.5 per cent). The lowest pass rates were observed among individuals originating from Bangladesh (44.3 per cent), Iraq (47.8 per cent) and Afghanistan (48 per cent). The data for the more recent period (third quarter of 2017 to fourth quarter of 2019) allow for more nuanced analysis. First, in the period, more than 394,000 individuals sat the test. Second, out of all tests taken almost two-thirds of them were in relation to a citizenship application. Third, while the average pass rate for all applicants taking the test as part of the settlement procedure was 81.7 per cent, the pass rate for the test in relation to citizenship applications was lower at 78.1 per cent (Home Office, 2020).

Also, Home Office data covering the period 2005-2019 indicate that the share of citizenship application refusals based on insufficient results of English test of Knowledge of Life in the UK varied across years. The peak year was 2007 when 
more than 16 per cent of applications were refused on this ground. In 2013, the year with the lowest share of refusals, less than 1 per cent of applications were refused (ibid.). However, such results should be analysed carefully, as it is the test itself which acts as a primary filter in the naturalisation application process. The results might indicate the lack of knowledge on the side of applicants that the KOLL condition must be successfully met before the beginning of the application.

Currently, the debate on the requirements related to naturalisation relates more to the content of testing rather than the existence of such requirements. According to the Home Office representative consulted, ${ }^{201}$ it is widely accepted and uncontroversial that the language requirement plays a role in the integration process of immigrants. The country expert stated that the feedback regarding the KOLL is provided mainly by organisations which deal with immigration and integration issues. ${ }^{202}$

An independent evaluation published in 2012 (Gidley et al., 2012) pointed to a number of themes in relation to citizenship acquisition. While since then the KOLL framework has been overhauled, some points remain relevant. First, the authors emphasise the role of free, accessible 'education for citizenship'. At that time, it was possible to attend ESOL courses with both language and citizenship components. They see the 2007 reform which reduced financing of such courses as a development which undermines integration aims, especially given the fact that the ESOL path was particularly valued by participants. Second, the survey conducted among non-EU citizenship applicants indicated that 95 per cent of applicants who opted for the test route used the handbook (Life in the UK); 93 per cent of whom saw the handbook as a useful study aid. Those who decided to follow the ESOL route did not have major problems with accessing the course, both in terms of waiting time and distance from a course provider. The majority of ESOL courses were provided by already existing institutions: Further Education Colleges or Community organisations (78 per cent of the respondents). However, one-in-four respondents indicated high costs as a barrier. Interestingly, the evaluation showed that citizenship applicants were more integrated in the UK's society and economy as compared to other migrants, but also British citizens. ${ }^{203}$

Another more recent study (Bassel et al., 2017) on citizenship applications and KOLL, also based on qualitative and quantitative data, provides a more complex picture. The research found that effort put into preparing for the test varied depending on the applicant's socio-economic status, but also their command of International (BICSPI) in March 2020. 
English. Accordingly, those with poorer knowledge of English depended to a larger extent on private preparatory courses (often expensive), but also other networks. Similarly, differences occurred when taking the test; here coming from an Englishspeaking country or environment (such as Canada) was a clear advantage. Further, the understanding of the purpose of the KOLL varied among the study participants. Some of them saw it as an immigration control device and not a facilitator of integration.

The UK Home Office representative consulted for this study ${ }^{204}$ stated that the assessment of whether KOLL meets the policy objectives presented at the inception is difficult. In principle, the representative stated the test is functioning, however it is difficult to assess to what extent the introduction of the tests is contributing to integration. The Home Office representative stated the test ensures applicants learn about British history and culture, which otherwise would not happen. The Home Office representative was of the view that stakeholders see the requirements positively.

The main stakeholders in the field of testing as defined by the Home Office representative include the Home Office, producer of the handbook (TSO) and outsourced test providers (currently PSI). Also, there is a number of course providers who offer tuition-based preparation for the tests. However, in no way are they related to the official process of policy preparation or implementation. There is no permanent engagement of stakeholders in an organised form. ${ }^{205}$

\subsubsection{Conclusions}

The requirements for the purpose of acquiring citizenship have a century-long history in the United Kingdom. Initially, they covered only language. However, the requirements in a more defined form are a more recent phenomenon and their development can be seen as a result of the government's quest for more integration among the migrant community.

Whereas the system of requirements has been relatively stable, its elements evolved over time. Accordingly, the Knowledge of Life in the UK component has changed from more everyday life-oriented questions to more history and culture assessment in line with changes in the textbook. As for the language component, the 'double route' system (which included participation in a course leading to acknowledgment of language skills) was abandoned and currently only the test

204 Information obtained from Home Office representative, Passport and Nationality Policy Unit BICS Policy and International (BICSPI) in March 2020. 
possibility exists. Also, over time, the quality of testing became more scrutinised and the tests are standardised.

Even if the debate on testing was embedded in a broader discussion on integration, it soon became used as a base for more radical proposals, such as regulating the number of migrants in the country.

Preparation of a proper environment for testing procedures (such as courses) requires considerable coordination, flexibility and resources. Otherwise, this niche can be filled by for-profit actors. Some participants of such courses find them excessively expensive and see them as another hurdle on the way to citizenship.

Apart from the tests' costs, an additional barrier is the significantly higher cost of attending a course. But costs related to childcare have also been noted. This last point is especially important as one of the goals of the test was to integrate women with an immigrant background.

When it comes to the handbook which serves as the basis for the test, several problems have been identified. A major one was that a part of the handbook was devoted to knowledge on contemporary politics, government structure etc. This information was subject to frequent changes not reflected in the book. Therefore, answering certain questions required reference to the information presented in the handbook and not the factual knowledge. In July 2020, a number of British historians signed an open letter calling for an official review of the handbook's history chapter. ${ }^{206}$

An important lesson for Ireland is the challenge of providing a consistent multilanguage assessment. Also, the role of multiple types of assessment, including participation in courses is seen as essential by applicants themselves. At the same time, it should be noted that there are exemptions from the language requirement, but also that the assessment of KOLL done for other purposes (such as Indefinite Leave to Remain) waives citizenship applicants from having to take it again. 


\subsection{CASE STUDY 5: ENGLISH LANGUAGE SPEAKING COUNTRIES OUTSIDE THE EU}

\subsubsection{United States}

The standardisation of civics testing for the purpose of naturalisation started in 1906 in the US. In the very early stages, the process focused on procedural aspects (such as forms, procedures and records) and it took a number of years to unify questions and topics used in testing. In 1918 the first citizenship textbook was developed, which has been changed a number of times. In 1950, the official body for naturalisation (currently called US Citizenship and Immigration Services) was established. Also at that time the requirement of writing, reading and speaking in English became officially required. From this time, applicants started preparing for the test by following a very structured course.

An important legacy of the period when it was judges who tested the applicants is the way tests have been conducted; they remain oral based on the premise that the US Citizenship and Immigration officer will adjust to the applicant's capacity (Van Ruyskensvelde and Ketch, 2018). Etzioni comments extensively on the role of the officers and sees such discretion as a way of implementing certain political priorities by street-level bureaucrats (Etzioni, 2007).

The current form of testing with a closed pool of questions and suggested answers was developed after the ratification of the Immigration Reform and Control Act in 1986 which aimed at regularising the stay of 2.7 million illegal migrants. According to the historian Jack Schneider, the questions were drafted over a weekend by two Immigration and Naturalization Service (INS) examiners (Schneider, 2010). ${ }^{207}$ Schneider emphasises that the list was not a subject of a political debate - in his words it
[...] reflected the views of a small group of individuals who were charged, not with the task of deliberation or debate, but with the same sort of myopic problem solving the agency had been doing for most of the century (ibid., p.2397)

The questions that are asked during an interview have been modified over time (with most recent modification in 2018), however, no major overhaul took place in spite of recommendations proposed by the expert group (Van Ruyskensvelde and Ketch, 2018). 
The study materials are available for free in different forms such as booklet, study cards or film. An integral part of the materials is the list of answers which includes a range of acceptable responses (allowing for diverse interpretations). The materials are prepared using plain English.

The questions focus on democratic values and principles, tolerance and rights as well as some historic knowledge and symbols. However, there are also questions testing 'contemporary knowledge' such as current laws, name of the President etc., and applicants are expected to be up-to-date with such types of information.

There is a pool of questions (100) and during an oral interview the US Citizenship and Immigration officer asks ten of them. It is enough to give six good answers to pass the test. Also, during an interview, the officer tests the language abilities in three respects: speaking, reading and writing. The writing and reading vocabularies are available online.

In the case of a person older than 50 years who has lived in the US for at least 20 years as a Green Card holder (permanent resident), or if a person is older than 55 years with 15 years of permanent residence, it is possible to pass the civics test in his/her native language (with assistance of an interpreter).

In the case of a person who reached 65 years of age and has at least 20 years of permanent residence, the pool of questions for the civics test is reduced from 100 questions to 20 .

Van Ruyskensvelde and Ketch (2018) list some studies which analyse both the content as well as validity of the civics test. Apart from the critiques relating to the content of the test - that its focus is on duties rather than rights - there are two points here. First, depending on the composition of questions, the test can be less or more challenging which means not every applicant stands an equal chance. Second, the research conducted revealed that the pass rate is higher for immigrants than for those who are native US citizens (the pass rate of 93 per cent and 63 per cent, respectively) which raises the question of 'super citizen' requirements.

An integral part of the civics test in the US is the assessment of knowledge of English. The interviewing officer asks an applicant to both read aloud a portion of text as well as to write some text down. The assessment of the language knowledge is discretional and depends only on the opinion of the officer. 
It is possible to attend another interview within the same application procedure if either the civics part or the language part has been failed.

\subsubsection{Australia}

The naturalisation policy in Australia since 1948 can be divided into periods. The first period was characterised by a very selective policy - the priority was given to British and Irish citizens who could receive Australian citizenship after one year of stay. Other Europeans qualified for citizenship after five years of stay. NonEuropean migrants could not apply for citizenship at all until 1956, following which a 15-year period of stay was required. It should be stated that British citizens could participate in Australian elections. In 1973 the naturalisation obligations became equal for all immigrants and were gradually liberalised. The baseline conditions were two years of residence in Australia and knowledge of basic English (Fozdar and Spittles, 2009). The tests of English were performed by a representative of the Ministry of Immigration and Citizenship during an interview. They involved a short conversation on the immigrant's life in Australia (Senate Legal and Constitutional Affairs Legislation Committee, 2017).

The introduction of the citizenship test (which simultaneously serves as tool for assessment of language knowledge) and its subsequent reforms are perceived by some observers as a result of the growing pressure on the politicians (Tavan, 2009). The main arguments present in the public discourse were that the Australian citizenship had lost value to immigrants (manifested in the non-take-up by immigrants), race riots, but also a more general anti-immigrant stance of some social and political actors. The political response was, first, extending the qualifying residence stay to four years, followed by the introduction of the citizenship test. The period between announcement and implementation of the policy was very short: it was first announced in late April 2006 and the test became operational on 1 October 2007 (Tavan, 2009).

The citizenship test (sometimes referred to as the 'values test') and the booklet Becoming an Australian Citizen were heavily criticised for omitting a multicultural perspective, the role of the Indigenous population and immigrants. The questions pertaining to the duties and privileges had to be answered correctly and the overall pass mark was 60 per cent. For those who participated in the English language lessons (i.e. completed at least 400 hours of English language tuition under the Adult Migrant English Program) and their level of language proficiency was still seen as insufficient, a language support might be provided. In this case, instead of standard 45 minutes, the test takes 90 minutes. 
The number of citizenship applications following the introduction of the test dropped significantly; while in the first months of 2007 it was no less than 11,000 applications monthly, the respective number in the late months of this year dropped more than by half. Also, the policy review launched by the subsequent (Labour) government indicated that the success rate was lower among individuals residing in Australia for humanitarian reasons (Fozdar and Spittles, 2009).

The first result of the review took place in 2009 and included the replacement of the Becoming an Australian Citizen booklet with Australian Citizenship - Our Common Bond, focusing more on the principles of multiculturalism and reconciliation and less on 'patriotism'. The parts of the booklet dealing with Australian history are non-testable. Also, the review resulted in dropping the mandatory questions on duties and obligations from the test, but at the same time, increasing the pass mark to 75 per cent. Further, the area of duties and obligations has been moved to the citizenship pledge.

Other recommendations, such as the publication of the booklet in other languages, have been implemented later (now the website features 38 different language versions). The materials are available online. There is no limit on the number of attempts. The citizenship test serves as a testing tool for the English language as well. The proficiency level is approximately B1 CEFR.

In 2017, another attempt to reform the citizenship test was proposed, however this reform has been removed from the agenda (discharged from the Notice Paper). The main proposed changes entailed introducing a separate language test with higher competence requirements by moving from International English Language Testing System (IELTS) Band 5 (B1/B2 CEFR) to IELTS 6 (B2 'advanced') which is equivalent to the level required for entering university education. ${ }^{208}$ Also, introducing questions pertaining to Australian values, a limit of three attempts to sit a test, and a two-year waiting period after a failed application were considered (Senate Legal and Constitutional Affairs Legislation Committee, 2017). Further, 'proof' of integration was proposed. ${ }^{209}$

\subsubsection{Canada}

Canada has a long-standing tradition of language testing. In 1994, the standardised citizenship testing was introduced - the tests replaced oral tests by citizenship judges. Two main reasons are given for the introduction of written tests; their 
lower costs as compared to the tests by judges, and the pace of testing, which was seen as a way of reducing backlogs in the citizenship applications.

The test reform of 2010 was to 'increase the value of Canadian citizenship' (Paquet). The reform entailed introducing more knowledge on social, political and military history. While it was criticised for omitting certain parts of human rights, Paquet maintains that the core idea has remained unchanged.

Currently, the test consists of 20 questions which need to be answered within 30 minutes. The questions can be either multiple choice or true/false. The questions are not public, but they are based on the booklet Discover Canada: The Rights and Responsibilities of Citizenship. This publication contains knowledge on the history, geography, economy, government, laws and symbols. The pass mark is 75 per cent. Winter (2018) argues that naturalisation process in Canada currently fails to deliver on the promise of putting 'Canadians by choice' on a par with 'Canadians by birth'. Testing creates boundaries between those can easily pass the test and those who struggle; and between those deemed 'culturally inferior' and 'real Canadians' at the very moment it aims to instil loyalty and belonging in the newly naturalised.

\subsubsection{Conclusions}

The brief description of requirements related to naturalisation procedure in Australia, Canada and the United States is important, as these three states are seen as pioneers in this respect. However, this presentation shows there are different ways citizenship requirements operate in these states.

In Australia, the citizenship test aims at assessing the knowledge of English. The test is written and is based on a textbook. In Canada the test is written and the basis for preparation is the handbook. In the United States, in turn, the civics test is performed by an immigration officer. The assessment is oral and an integral part of it concerns the language. The test is based on predefined list of questions and answers.

In all three countries, the civics requirements are based on preparatory materials. In the United States, the applicants are provided with a set of learning aids, tailored to applicants' competencies.

Even though Australia, Canada and the United States have a long history of requirements and one could expect well-established standards and procedures, it seems that the modern tests have gone through a period of trial and error and have been subject to a series of adjustments. 
102 International practices on civics and language requirements linked to naturalisation 


\section{CHAPTER 6}

\section{Policy implications}

This report set out to provide an overview of language and civic knowledge or integration requirements linked to naturalisation in EU Member States and the UK. In focusing in more depth on a selection of four European countries, namely Belgium, Finland, Portugal and the UK, and the situation in three English-speaking countries outside of Europe, the report sought to identify common trends, if any, and useful insights in the development and implementation of such requirements.

Article 12 of the Migrant Integration Strategy commits to examining the introduction of language and civic requirements for citizenship applicants. The following section offers some considerations arising from the review of literature, overview of language and civic requirements, and case studies, to inform the examination of such requirements in the Irish context.

\subsection{INTRODUCTION OF REQUIREMENTS IN IRELAND WOULD REPRESENT A SIGNIFICANT NEW POLICY DIRECTION}

While challenges relating to the naturalisation process, such as processing times, application costs, and the discretion applied to naturalisation conditions, continue to be highlighted by naturalisation applicants and NGOs (see for example Becker and Cosgrave, 2013; Huddleston et al., 2015), Ireland's citizenship requirements have been ranked relatively favourably in an international context. Goodman (2010) categorises Ireland's citizenship rules as 'enabling', whereby citizenship is viewed as a mechanism for establishing equal status and rights and therefore enabling, rather than 'rewarding', integration. Similarly, in a review of policies granting access to nationality, MIPEX ranked Ireland 14 out of 38 countries, reporting Ireland's naturalisation requirements and procedure to be 'halfway favourable' (Huddleston et al., 2015). ${ }^{210}$

The introduction of language or civic requirements would represent a significant new direction for Ireland. Integration policy in Ireland has underlined that citizenship is a key measure to facilitate the integration of migrants into Irish society (Department of Justice, Equality and Law Reform, 1999; Office of the Minister for Integration, 2008). Research on the Irish labour market using 2016 Census microdata finds that non-EEA migrants who are Irish citizens are both more 
likely to be employed, and when they are employed to have a better job, than those who are not Irish citizens (McGinnity et al., 2020). ${ }^{211}$ This suggests that the acquisition of Irish citizenship may facilitate labour market integration though the direction of causality is uncertain. It would therefore be important to scrutinise the role language and civic requirements would play in the acquisition of Irish citizenship, including whether such requirements would support the acquisition of citizenship and the integration process, or act as a deterrent to the acquisition of citizenship. It may also be useful for those considering the introduction of language and civic requirements in Ireland to examine the reasons for which non-Irish nationals apply for Irish citizenship and the impact of Irish citizenship on integration outcomes. These questions may help policymakers better understand the dynamics of citizenship acquisition and how requirements, if any, may best be used in the process.

\subsection{NO ONE-FITS-ALL APPROACH}

Each individual country-level approach to citizenship requirements must be seen as part of the wider citizenship and migration policy context. A debate on a 'civic turn' has emerged; while one can observe a growing number of countries which introduce various requirements, their content is strikingly different. An in-depth analysis of requirements applied in each country is beyond the scope of this study, except in relation to the selected case studies. However, a key finding of this report is that there is a great diversity in approach towards language and civic knowledge or integration requirements across EU Member States and English-speaking countries. While in the most general terms such diversity can be linked to the socioeconomic variation in the European states, it also should be seen in the context of the migration flows - their size, origins and nature.

Chapter 2 sought to locate Ireland in a European overview of migration trends. Ireland belongs to a small group of European countries where the majority of migrants arrive for work or education. In other EU Member States, the number of people migrating for family reasons exceeds those arriving for employment. Furthermore, Ireland has the highest proportion of foreign-born residents born in other European countries, while most other EU Member States have a larger proportion of residents born in non-EU countries. Three out of four countries examined in the European case studies have a colonial past. In the United Kingdom and Portugal in particular, the dominant share of migration flows originates from former colonies or countries with strong historical ties. Therefore, past immigration policy decisions easing or restricting access to these states, the process of decolonisation, as well as family reunification decisions, have created challenges specific to these countries. To some extent these challenges shaped the nature of citizenship requirements. In particular, immigrants from former colonies 
often speak the same language as in the host country, so the requirement for language training is quite different. At the same time, individuals seeking international protection, their families and immigrants from 'new' destinations, created yet a different context for citizenship requirements. This is why one might observe the 'civic turn' across the board since the 1990s accompanied by a number of exemptions. While Belgium also has a colonial past, most migrants are European and migration flows have been influenced to a large extent by post-war labour agreements with third countries and related family migration policies. Finland in contrast was linked historically more to neighbouring countries.

The specific migration and policy context that has shaped language and civic requirements must be kept in mind when examining how such requirements operate in other countries. Nevertheless, the countries examined provide some valuable learnings for language and civic requirements under consideration in Ireland.

\subsection{FORMAT OF REQUIREMENTS AND STATE SUPPORTS}

In many of the countries examined, citizenship applicants are provided with multiple avenues for meeting requirements. Options for demonstrating language proficiency range from completion of a language course, taking a language exam or submitting documentation on educational attainment at secondary or tertiary level. In the majority of countries that include a civic requirement, knowledge is examined by means of a written exam, while applicants in some countries are assessed by way of interview. Belgium and Luxembourg stand out in in providing applicants with an option to complete an integration course to satisfy citizenship requirements. Strik (2013) suggests that alternatives to exams may allow the State to tailor requirements and supports to persons with different linguistic capabilities or needs.

No comprehensive information is available on the cost to the countries examined in implementing such requirements. Nevertheless, it is apparent that the introduction of such requirements entails significant cost to the State in terms of development of testing and course format and content, administration of tests/courses, evaluation and provision of learning materials and/or (co-)financing preparatory courses. Such requirements also potentially give rise to considerable financial implications for citizenship applicants, which may mean that financially disadvantaged migrants may not feel in a position to apply. The cost implications of introducing language and civic requirements in the naturalisation process in Ireland would therefore need to be examined prior to the introduction of such requirements. 
Supports offered to migrants by the State vary considerably across the countries examined. In all four European case studies some form of support exists, including free courses or preparatory material. The availability of such support is viewed by citizenship applicants as integration in and of itself. However, some EU Member States require applicants to prove civic knowledge yet do not provide supports for the acquisition of such knowledge. In addition, practical challenges to accessing courses including course costs in the Netherlands and the UK, and a lack of access to transport and affordable childcare in Belgium, was noted. As observed in the UK case study, the gap in State supports may be filled by private providers offering courses to migrants; however such courses may come at significant cost to the participant. The introduction of requirements in the absence of a range of accessible and tailored State supports, and the potential costs associated with an exam or course, may hinder certain migrants from meeting the necessary requirements for citizenship (for example those living in areas with no course provided nearby and/or no available transport, migrants with childcare needs, those with limited financial resources). This is contrary to the stated aims of ensuring integration.

If such requirements were to be introduced, further research into the most appropriate and fair format for requirements, and their potential impact, prior to their introduction would be essential.

\subsubsection{Language requirements}

Language skills can facilitate integration to the labour market, as well as to society more generally. Recent research using Census 2016 microdata has shown that immigrants in Ireland with better self-rated English language skills are more likely to be employed and have better jobs when they are employed (McGinnity et al., 2020). Fahey et al. (2019), analysing the residential distribution of immigrants in Ireland, find that while there is no evidence that migrants in general are concentrated in disadvantaged areas in Ireland. However, migrants with poor English language skills do tend to live in areas of higher unemployment, particularly in the urban areas of Dublin, Cork and Limerick, suggesting that this group may be disadvantaged relative to others. ${ }^{212}$ Language assessments can guide and assist migrants in their learning. A challenge arises when language assessments are used to 'measure' integration. Rocca et al. (2020) have found that a direct relationship between societal integration and language proficiency alone is not supported by research. Thalgott (2017) further argues that although language competences are an important component for integration, they cannot be a precondition for integration, since acquiring a language is potentially a lifelong process. In addition, while a certain level of fluency may be necessary to function independently in a

212 There is surprisingly little evidence of the impact of English language skills on integration among adult migrants in Ireland, at least from representative sources, primarily because most surveys do not measure English language skills. The Census of population is an important exception in this regard. 
new environment, even in the labour market, linguistic requirements differ significantly according to the job. English language skills may be less relevant for migrants picking mushrooms or packing meat than for those caring for children, adults or those who are sick.

As set out in Chapter 3, the level of language proficiency that EU Member States and the UK require of applicants varies from no clear requirement, to A1, A2, B1, and B2 level on the Common European Framework of Reference for Languages (CEFR), with more than half of the countries examined setting the required level at B1 or above. Böcker and Strik (2011) and the Council of Europe (Rocca et al., 2020) argue that the variety in levels demanded of citizenship applicants across Member States reflects the use of language requirements primarily as a symbolic function rather than a response to evidence of language needs for integration.

The Council of Europe cautions against the use by countries of a particular level of the CEFR as a measure for linguistic integration for the purposes of residency or citizenship requirements, highlighting that the CEFR was not developed with the needs of adult migrants in mind. Proficiency levels are intended to be used selectively and to be adapted to the situation, needs, abilities and educational experiences of all learners (Little, 2008, 2012; Council of Europe, 2014; Rocca et al., 2020). Countries also tend to apply the same proficiency level to reading, writing, listening and speaking. For language requirements to represent real language needs, the Council of Europe recommend differentiated requirements for each competency would be more appropriate and reference to be made to the training goals of migrants in relation to employment, personal, social, cultural and other integration in the host society (Little, 2008; Council of Europe, 2014; Rocca et al., 2020). In line with guidance provided by the Association of Language Testers in Europe (ALTE) to policymakers, conducting a needs analysis prior to the introduction of language requirements is essential, both to collect information about migrants' geographical, language and skills backgrounds and the linguistic demands they are likely to encounter, as well as the needs of stakeholders such as employers, educators and the wider public, and to address the impact a language requirement would have on these groups. A needs analysis should also consider alternatives to tests, such as attendance at a language course, or evidence of educational background or training, and what the challenges and disadvantages of these options may be, compared to having a standardised test in place (Council of Europe, 2016). If language training and testing is designed to facilitate integration, it should carefully consider those who are excluded by design of the test.

On the basis of a comparative review of naturalisation procedures across Europe, Bauböck et al. (2013) emphasised the need for any language requirements linked to naturalisation to reflect the level of State language support provided. Chapter 3 
and case studies highlight that several countries that link language requirements to naturalisation offer language supports to migrants free of charge. The Netherlands is a notable exception in this regard. In 11 Member States language support is provided as part of an integration programme (FRA, 2017). In countries such as Austria and the Netherlands successful completion of the integration course is a requirement for naturalisation.

There is considerable demand for English language skills in Ireland, and English language training is provided through programmes offered by a network of 16 education and training boards (Arnold et al., 2019). However, English language provision has developed in the absence of an overall national strategy, and demand for English language training currently far exceeds supply (Kett, 2018). Migrant organisations have expressed concerns about the lack of a structured framework for the provision of tailored English language supports to non-EU nationals (Arnold et al., 2019). There is also a lack of awareness among service providers and migrants about language training options (ibid.). The Further education and training strategy 2014-2019, developed by SOLAS, noted that English for speakers of other languages (ESOL) classes are provided to meet the needs of learners with a high level of education and professional and skilled backgrounds. The strategy acknowledged that a significant number of learners have had a low level of formal education in their country of origin and can therefore lack basic literacy skills (SOLAS, 2014). The need for a national framework for publicly funded ESOL provision, with priority for low-skilled and unemployed migrants, has therefore been emphasised by SOLAS and Education and Training Boards Ireland (Kett, 2018). In 2018, they issued 24 recommendations to inform the development of ESOL provision (Kett, 2018). This series of recommendations builds on previous reports that both urged the development of a national ESOL strategy (Irish Vocational Education Association, 2001; Howarth et al., 2008).

The introduction of a language requirement would require that consideration first be given to the availability and accessibility of English language courses and supports currently in place in Ireland and their capacity to meet demand should language acquisition be linked to citizenship. It would also be important to consider where language requirements for citizenship would sit in the further development of ESOL provision in Ireland, taking into account previous recommendations in this regard.

\section{Irish language}

Ireland's bilingualism cannot be ignored in the discussion on language requirements for new citizens. To date, integration policy has focused on the promotion of English language acquisition as a tool for integration. The current Migrant Integration Strategy addresses the Irish language in the context of the lack of representation of migrants in the public sector, noting that the Irish language 
requirement for primary school teachers acts as a barrier in this regard (Department of Justice and Equality, 2017).

As Irish and English are recognised as Ireland's two official languages, the presence of more than one national language or minority languages was an important consideration in the European case studies selected for further analysis in this report. In Belgium, Finland and the UK, where more than one language is officially recognised, citizenship applicants may choose the language in which they wish to demonstrate their proficiency. As discussed above, UK law provides that naturalisation applicants may prove proficiency in Welsh and Scottish Gaelic, in addition to English, although as discussed earlier there is some debate as to whether proving knowledge of Welsh or Scottish Gaelic is effectively provided for in practice (Mac Síthigh, 2018).

If a language requirement were to be introduced, regard should be given to providing applicants with the option to demonstrate proficiency in Irish as well as English. Providing opportunities to learn Irish may promote social and cultural integration and facilitate employment in sectors that require proficiency in Irish language, while contributing to efforts to encourage the use of Irish more broadly (Healy, 2007; Feldman et al., 2008). As with English, the introduction of Irish as an option would entail consideration of the ways in which proficiency in Irish can be demonstrated, including detailing the level and form of Irish qualification accepted for the purpose of acquiring citizenship. Similar to English language supports, it would be necessary to consider the availability of resources and supports for the acquisition of the Irish language and the promotion of opportunities to learn Irish among migrant communities.

\section{Irish Sign Language}

Since 2017, Irish Sign Language (ISL) is officially recognised in Ireland. The Irish Sign Language Act 2017 recognises the right of Irish Sign Language (ISL) users to use ISL as their native language. ${ }^{213}$ As discussed in Chapter 3, Finland is the only country that provides that an applicant for naturalisation can satisfy language requirements through sign language and has been highlighted as an example of good practice in this regard (Waddington, 2013).

Should a language requirement be introduced for citizenship applicants in Ireland, consideration should be given to measures for ensuring language requirements do not pose a barrier to non-Irish national members of the deaf community applying for citizenship. These may include an exemption from the language requirement 
for deaf applicants or including an equivalent ISL prerequisite to allow deaf applicants with proficiency in ISL to prove their ISL skills. In the case of the latter, the way in which proficiency in ISL can be demonstrated and provision of necessary supports to allow deaf non-Irish nationals to learn ISL would also need to be addressed.

\subsubsection{Civics requirements}

Chapter 4 highlighted that countries adopt a variety of methods for assessing civic knowledge/integration, including written exams, interviews, or completion of an integration course. Similarly, the content of civic requirements varies across countries. Much debate has arisen about the contents of such requirements in some countries and their impact on integration. Where the focus of civics exams is on history, traditions and values, the level of knowledge demanded may lead to a phenomenon of 'super-citizenship' or 'perfect citizenship', whereby citizenship applicants are expected to have a more thorough knowledge of a country than citizens born in the host country (Bauböck et al., 2013; Carrera, 2009; Badenhoop, 2017). Of course, the extent to which the test effectively requires knowledge of society or 'assimilation' into the host-country values, however that is defined, varies. As discussed in Chapter 4, research conducted with people who have taken citizenship tests in some EU Member States report mixed views on the knowledge tested, including the usefulness and relevance of the information to integration.

Rocca et al. (2020) suggest that if the goal is to promote the societal integration of migrants, requirements should focus on learning opportunities such as courses, rather than on exams. In addition, Bauböck et al. (2013) stressed that a civic requirement should only be introduced where basic civic knowledge is required of all citizens. Indeed, in some of the countries examined, exams or courses, such as courses provided to migrants in Luxembourg and Belgium, focus on more practical knowledge for living in the host country, such as information on rights, access to services and the political system and institutions. The Council of Europe (2014) recommend that civic requirements should serve no other purpose than to provide migrants with information to supplement the experience migrants have already acquired of life in the country, where they sometimes have lived for a long period of time. The format and content of any future civic requirements would therefore be important to consider. The content of requirements should be devised with the aim of providing migrants with necessary information to facilitate their integration in Ireland and should not be tailored adversely towards any minority religious or other group. Regard should be had to opportunities for acquiring civic knowledge already in place, such as courses and information currently offered by the State and community organisations to migrants, or components of language courses that impart knowledge and information on living in Ireland. 
The language in which a civic requirement must be satisfied, be it through an exam or attendance at an integration or orientation course, is also an important consideration. As highlighted in Chapter 4, civic requirements may act as a de facto language requirement. Most civic requirements applied in the countries examined are assessed in an official language, with the exception of Luxembourg, which allows applicants to complete courses in English in addition to the three official languages; and Belgium, in which some integration courses operating at regional level include components provided in languages of the country of origin of migrants or in a contact language. Rocca et al. (2020) suggest that countries that allow applicants to satisfy requirements in their first language provide a more valid measure of civics knowledge acquired. They provide the example of Norway, in which the exam for permanent residency is offered in one of 28 different languages, with preparation courses also available in the 28 languages.

\subsection{REQUIREMENTS AND SUPPORTS TAILORED TO INDIVIDUAL NEEDS}

The mapping of language and civic requirements in this study shows that exemptions or adapted requirements, where provided for, vary from one country to another and there is a lack of consistency across the exemptions provided. The most common exemptions provided are for age reasons and for persons who have attained a certain level of education in the host country.

As discussed in Chapter 3, the Council of Europe's project on the Linguistic Integration of Adult Migrants (LIAM) and the Association of Language Testers in Europe (ALTE) have devised guidelines for policymakers developing language testing for citizenship. The guidelines underline the need for testing not to discriminate against candidates with special requirements (ALTE, 2016).

Waddington (2013) notes that the way in which language and civic requirements operate may make it difficult, or impossible, for certain persons with disability to acquire citizenship. Certain requirements may be discriminatory towards people with disabilities, such as people who are unable to take an exam in the standard way or who have an intellectual disability and are unable to acquire the required knowledge (Waddington, 2013). Cera (2017) recommends positive measures and accommodations must be provided to ensure people with disabilities have the opportunity to apply on an equal basis with other applicants. This applies to both training offered prior to testing and adapted testing methods (Waddington, 2013). However, Cera (2017) notes that positive measures may nevertheless not ensure access for all persons with disabilities, in which case exemptions should be provided to ensure access to citizenship. Not all countries examined in this report address the needs of people with disabilities in citizenship law or information for applicants, which reflects the lack of information on, and consideration given to, people with disabilities applying for citizenship (Waddington, 2013). Few countries 
were found to offer adapted procedures for people with a disability to fulfil language and civic knowledge/integration requirements and participate in measures to facilitate acquisition of knowledge. For example, Finland is the only country that provides that an applicant can also meet the language requirement by proving their skills in sign language. Several countries examined in this study do not require people with disabilities to satisfy such requirements. However, Waddington (2013) questions whether this demonstrates good practice for people with disabilities. No information is available on how such exemptions are applied in practice and whether people with disabilities still experience barriers even in countries where exemptions are applied. Waddington (2013) suggests the provision of exams, courses or other assessment methods that are adapted to meet the needs of people with disabilities would facilitate the acquisition of knowledge required for citizenship, where requirements exist.

Very few exemptions or adapted requirements were also found in countries examined for persons who are illiterate or have low levels of literacy. As noted in Chapter 4 and the case study on the UK in Section 5.5, research conducted with people who had taken the Life in the UK Test reported that those who had lower levels of English, little formal education or who lacked computer literacy found the test and learning materials more difficult than people who reported a good level of English or were from English-speaking countries (Strik et al., 2010; Gidley et al., 2012). The Council of Europe suggests that if requirements are to be considered, all learners, including those who are illiterate or have low levels of literacy, those with low levels of prior formal education, and vulnerable groups such as refugees, should be provided with effective learning opportunities that take into account their level of educational attainment, their learning needs and individual capacities (Rocca et al., 2020).

\subsection{TENDENCY TOWARDS INTRODUCTION OF STRICTER REQUIREMENTS ONCE IN PLACE}

The mapping exercise and case studies show an increased tendency among countries to not only introduce requirements for citizenship over the last two decades, but also to enact stricter requirements over time once such requirements are in place. This is supported by literature and a Council of Europe survey carried out among member states (Strik et al., 2010; Bauböck and Goodman, 2012; Pochon-Berger and Lenz, 2014; Wodak and Boukala, 2015; Rocca et al., 2020). The trend is particularly evident when looking at language requirements. Rocca et al. (2020) found that some EU Member States have gradually increased the level of language proficiency required to the B1 level of the Common European Framework of Reference for Languages (CEFR), having previously required applicants to provide $\mathrm{A} 1$ or $\mathrm{A} 2 \mathrm{CEFR}$ level. The Netherlands, which currently requires applicants to provide an $A 2$ level of proficiency in Dutch, intends to increase the requirement to B1 level. Prior to 2020, applicants in France were required to only demonstrate 
proficiency in oral French at B1 level. From April 2020, applicants must also take a written test at B1 level (EMN France, 2019). Such trends are also evident in the non-EU English-speaking countries. An attempt to increase language requirements was a part of the 2017 reform proposal in Australia, which proposed to create a separate language test and increase the required level from 'basic' to 'competent' language use (to IELTS Band 6, which is roughly equivalent to 'advanced' B2 CEFR required for entering university).

Strik (2013) expresses concern that although the introduction of such requirements is framed as a response to concerns about integration, the tightening of restrictions reflects their use as tool for immigration control. One could argue that the states which are most advanced in imposing requirements related to obtaining citizenship (in addition to permanent/long-term residence), such as Denmark or the Netherlands, perceive the problem of a lack of integration as particularly acute (Jensen et al., 2017; van Oers, 2014). Strik argues that if a consequence of such requirements is to reduce the number of migrants arriving or remaining in the countries concerned, they are a regressive step. The Council of Europe therefore highlights the need for research to determine whether the introduction of stricter requirements has a positive, or negative, impact on integration (Strik, 2013; Beacco et al., 2017; Rocca et al., 2020).

\subsection{EVALUATION}

One of the Common Basic Principles for Immigrant Integration Policy in the EU is the understanding that developing clear goals, indicators and monitoring mechanisms are necessary to adjust policy and evaluate progress on integration (Council of the European Union, 2004). Literature examining civic requirements and policy reports and recommendations issued by the Council of Europe have underlined that the development of integration measures must go hand in hand with robust and independent evaluation systems to measure their impact and effectiveness (Bauböck and Goodman, 2012; Strik, 2013; Carrera and Vankova, 2019). In addition, they recommend that exams or courses linked to naturalisation requirements should conform to accepted standards of quality and independent quality control (Council of Europe, 2016; Rocca et al., 2020).

A key question raised during this research is to what extent language and citizenship requirements lead to better integration outcomes. As highlighted in Chapters 3 to 5 that looked at EU Member States and selected case studies, very little information is available on evaluations, if any, of such requirements in the context of the acquisition of citizenship. In spite of the increase in Member States that have adopted language and civic requirements in recent years, some of the policymakers consulted in the course of the research stated there is a lack of evidence relating to whether or not such measures support national policy aims. 
Independent evaluations have been carried out on components of naturalisation requirements, such as the integration courses in Germany, integration courses at regional level in Belgium and the Life in the UK test; however the effect of including such measures as part of the naturalisation process has generally not been the focus of research. It seems to be the assumption of many policymakers that these courses will facilitate integration, but, particularly in the case of civic knowledge, it is far from clear that this is the case. Due to the sparse information on the effect of measures adopted in European countries on integration of migrants, it is difficult to reach any conclusions about the long-term effects of language and civic integration requirements linked to citizenship. There is a need for more research to determine the impact of language and civic requirements on integration outcomes.

An important part of policy development and evaluation also includes the views of the people subject to integration measures or requirements. The Common Basic Principles underline that the participation of immigrants in the formulation of integration policies and measures may result in policy that better serves immigrants and enhances their sense of belonging (Council of the European Union, 2004).

Little information is available on consultation with migrants prior to the introduction of requirements in countries examined. In the UK, the Advisory Group established to advise the Home Secretary on introducing a Life in the UK test consulted with NGOs and migrant organisations as part of its reporting process. The Advisory Group also commissioned research to better understand views among the migrant community on UK citizenship, the naturalisation process and factors influencing the decision to apply for citizenship (Home Office, 2003). An evaluation conducted in the Belgian Walloon region highlighted a lack of consultation with the migrant community who are obliged to complete integration courses as a gap in policy development in Belgium (Gossiaux et al., 2019). There are some examples of involvement of people with a migrant background and/or representative organisations in evaluations of language and civic requirements. Independent evaluations of the naturalisation process in the UK and the integration courses at regional level in Belgium have involved research with people who have taken part in and completed the exam or integration courses. In Estonia, the monitoring of integration at national level involves surveys of the migrant population, including in relation to questions on the citizenship process.

Research on the development of a national English language policy for immigrants highlighted that while most people consulted emphasised the importance of English language proficiency for integration into Irish society, the majority objected to linking language requirements to eligibility for citizenship, including due to the concern this may lead to the exclusion of some migrants (Horwath Consulting 
Ireland et al., 2008). In line with these principles, the views of people eligible to apply for citizenship and who have become Irish citizens through naturalisation should be included in considerations being given by the Department of Justice and Equality to the introduction of any citizenship requirements in Ireland, in addition to the provision of necessary supports to satisfy such requirements, and their subsequent evaluation. 



\section{REFERENCES}

Adam, I. and M. Martiniello (2013). 'Divergences et convergences des politiques d'intégration dans la Belgique multinationale. Le cas des parcours d'intégration pour les immigrés (Divergences and convergences in integration policies in multinational Belgium. The case of integration courses for immigrants)', in Revue européenne des migration internationales, Vol. 29, No. 2, pp. 77-93.

ALTE (2016). Language tests for access, integration and citizenship: An outline for policymakers, Cambridge: Association of Language Testers in Europe (ALTE), available at https://alte.wildapricot.org/resources/Documents/LAMI\%20Booklet\%20 EN.pdf.

Apers, C. (2018). 'Edito: Aménagements du Code de la nationalité au milieu du jeu de quills (Editorial: Amendments to the Code of nationality in the middle of a skittles game)', in Newsletter No. 143, pp. 2-4, Brussels: Association pour le droit des étrangers, available at www.adde.be/publications/newsletter-juridique.

Arnold, S., E. Quinn, S. Groarke, F. McGinnity and C. Durst (2019). Policy and practice targeting the labour market integration of non-EU nationals in Ireland, European Migration Network, ESRI Research Series No. 89, Dublin: Economic and Social Research Institute.

Badenhoop, E. (2017). 'Calling for the Super Citizen: Citizenship ceremonies in the UK and Germany as techniques of subject-formation', in Migration Studies, Vol. 5, No. 3, pp. 409-427. https://doi.org/10.1093/migration/mnx053.

Barbulescu, R. (2013). Naturalisation Procedures for Immigrants: Romania, EUDO Citizenship Observatory, Florence: European University Institute, available at https://cadmus.eui.eu/bitstream/handle/1814/29795/NPR_2013_17Rom ania. pdf?sequence $=1 \&$ isAllowed $=y$.

Barrett, A., F. McGinnity and E. Quinn (eds.) (2017). Annual Monitoring Report on Integration 2016, Dublin: Economic and Social Research Institute.

Bassel, L., P. Monforte, D. Bartram, K. Kamran and B. Misztal (2017). The UK Citizenship Test Process: Exploring Migrants' Experiences, Leicester: University of Leicester, available at www2.le.ac.uk/departments/sociology/research/uk-citizenshipprocess/final-report-1.

Bauböck, R. (2006). 'Citizenship and migration - concepts and controversies', in Bauböck, R. (ed.), Migration and Citizenship. Legal Status, Rights and Political Participation, Amsterdam: Amsterdam University Press.

Bauböck, R. and S.W. Goodman (2012). EUDO Citizenship Policy Brief 2, EUDO Citizenship Observatory, Florence: European University Institute. 
Bauböck, R., I. Honohan, T. Huddleston, D. Hutcheson, J. Shaw and M. Vink (2013). Access to citizenship and its impact on immigrant integration. EUDO Citizenship Observatory, Florence: European University Institute.

Beacco, J.-C., H.-J. Krumm and D. Little (2017). 'Introduction (English version)', in Beacco, J.-C., H.-J., Krumm, D. Little, P. Thalgott, and Council of Europe, The linguistic integration of adult migrants, Berlin/Boston: de Gruyter.

Becker, H. and C. Cosgrave (2013). Naturalisation Procedures for Immigrants: Ireland. EUDO Citizenship Observatory, Florence: European University Institute.

Böcker, A. and T. Strik (2011). 'Language and Knowledge Tests for Permanent Residence Rights: Help or Hindrance for Integration?', European Journal of Migration and Law, Vol. 13, No. 2, pp. 157-184.

Bonifazi, C. and S. Strozza (2001). 'International migration in Europe in the last fifty years', in: Bonifazi C. and Gesano G. (eds.), Contributions to international migration studies, Rome: Istituto di Ricerche sulla Popolazione e le Politiche Sociali.

Borevi, K., K.K. Jensen and P. Mouritsen (2017). 'The civic turn of immigrant integration policies in the Scandinavian welfare states', in Comparative Migration Studies, Vol. 5 No. 9, https://doi.org/10.1186/s40878-017-00524.

Brander (2011). 'The 2011 Amendment of the Finnish Nationality Act', RSCAS/EUDO Citizenship.

Breda, J. (2013). ANED 2013 Task 3 and 4 - Country reports on citizenship and political participation. Country: Belgium, Academic Network of European Disability Experts, available at www.disability-europe.net/theme/politicalparticipation?country=belgium.

Brubacker, R. (1992). Citizenship and Nationhood in France and Germany. Harvard: Harvard University Press.

Bruzos, A. I. Erdocia and K. Kamran (2018). 'The path to naturalization in Spain: Old ideologies, new language testing regimes and the problem of test use', in Language Policy, Vol 17, pp 419-441 Springer. https://doi.org/10.1007/s10993-017-9452-4.

Byrne, B. (2017). 'Testing Times: The Place of the Citizenship Test in the UK Immigration Regime and New Citizens' Responses to it', in Sociology, Vol. 51, No. 2, pp. 323-338.

Carrera, S. and Z. Vankova (2019). Human rights aspects of immigrant and refugee integration policies: A comparative assessment in selected Council of Europe member states, Special Representative of the Secretary General on migration and refugees, Strasbourg: Council of Europe, available at https://rm.coe.int/168093de2c.

Carrera, S. (2006). A Comparison of Integration Programmes in the EU, Challenge Papers No. 1, Brussels: Centre for European Policy Studies.

Carrera, S. (2009). In Search of the Perfect Citizen? The Intersection between Integration, Immigration and Nationality in the EU, The Hague: Brill. 
CBAI CRAcs (2016). Parcours d'accueil pour primo-arrivants: Rapport annuel (Reception pathways for new-arrivals), Brussels: CBAl, available at www.cbai.be/resource/docsenstock/cohesion_sociale/Parcours\%20d\%27 accueil\%20-\%20Rapport\%202016.pdf.

Cera, R. (2017). 'Article 18 [Liberty of Movement and Nationality]' in Della Fina, V., R. Cera and G. Palmisano (eds.), The United Nations Convention on Persons with Disabilities: A commentary, Cham, Switzerland: Springer.

Charalambidou, N. (2013). Naturalisation Procedures for Immigrants. Cyprus, EUDO Citizenship Observatory, Florence: European University Institute.

Christopoulos, D. (2013). Naturalisation Procedures for Immigrants: Greece, EUDO Citizenship Observatory, Florence: European University Institute, available at https://cadmus.eui.eu/bitstream/handle/1814/29784/NPR_2013_09Greece.pdf?sequence $=1 \&$ isAllowed $=y$.

CIRÉ (2017). 'Des politiques d'intégration détournées de leur objectif' (Integration policies diverted from their objective), Brussels: Coordination et initiatives pour réfugiés et étrangers (CIRÉ), available at www.cire.be/wpcontent/uploads/2017/06/20170525-nationalite-integration.pdf.

Cook, M.L. (2018). 'Portugal's Immigration and Integration Policies: a Case Apart?', in Journal of International Migration and Integration, Vol. 19, No. 3, pp. 771-789.

Council of Europe (2014). The linguistic integration of adult migrants: From one country to another, from one language to another, Strasbourg: Council of Europe.

Council of Europe (2016). Language tests for access, integration and citizenship: An outline for policy makers, Association of Language Testers in Europe, Strasbourg: Council of Europe, available at www.alte.org/resources/Documents/LAMI\%20Booklet\%20EN.pdf.

Council of the European Union (2004). Justice and Home Affairs, 2618th Council Meeting: Immigrant Integration Policy in the European Union, Press release, available at www.consilium.europa.eu/ueDocs/cms_Data/docs/pressData/en/jha/82 745.pdf.

CSO (2019). 'Population and Migration Estimates April 2019', Dublin: Central Statistics Office, www.cso.ie/en/releasesandpublications/er/pme/populationandmigratio nestimatesapril2019.

DeBono, D. (2013). Naturalisations Procedures for Immigrants: Malta, EUDO Citizenship Observatory, Florence: European University Institute Research Repository, available https://cadmus.eui.eu/bitstream/handle/1814/29791/NPR_2013_30Malta.pdf?sequence=1\&isAllowed=y.

De Cuyper, P. (2010). Deel 2. Het inburgeringsbeleid in Vlaanderen: de efficiëntie en effectiviteit geëvalueerd (Part 2. Integration policy in Flanders: evaluation of its efficiency and effectiveness). Leuven: HIVA. 
De Cuyper, P. and J. Wets (2007). Diversiteit in integratie. Een evaluatie van de vormgeving, efficiëntie en effectiviteit van het Vlaamse inburgeringsbeleid (Diversity in integration. An evaluation of the design, efficiency and effectiveness of the Flemish integration policy). Leuven: HIVA.

De Cuyper, P., M. Lamberts, F. Pauwels and C. Vets (2010). Deel 1. Inburgering in Vlaanderen (Part 1. Integration in Flanders). Leuven: HIVA.

De Jonghe, D. and M. Doutrepont (2013a). 'Le code de la nationalité belge, version 2013: De "Sois Belge et intègre-toi " a "Intègre-toi et sois Belge " (première partie) (The Code of Belgian nationality, version 2013: From 'Be Belgian and integrate' to 'Integrate and be Belgian' (first part))', in Journal des tribunaux, Vol. 17, No. 6519, pp. 313-319.

De Jonghe, D. and M. Doutrepont (2013b). 'Le code de la nationalité belge, version 2013: De "Sois Belge et intègre-toi " a "Intègre-toi et sois Belge " (Deuxième partie) (The Code of Belgian nationality, version 2013: From 'Be Belgian and integrate' to 'Integrate and be Belgian' (second part))', in Journal des tribunaux, Vol. 18, No. 6520, pp. 329-338.

Denham, J. (2002). Building Cohesive Communities: A Report of the Ministerial Group on Public Order and Community Cohesion, London: Home Office.

Department of Justice and Equality (2013). Policy Document on Non-EEA Family Reunification, available at www.inis.gov.ie/en/INIS/Family\%20Reunification\%20Policy\%20Documen t.pdf/Files/Family\%20Reunification\%20Policy\%20Document.pdf.

Department of Justice and Equality (2017). The Migrant Integration Strategy: A Blueprint for the Future, Dublin: Department of Justice and Equality, available at www.justice.ie.

Department of Justice and Equality (2019). The Migrant Integration Strategy 20172020: Progress Report to Government, Dublin: Department of Justice and Equality, available at www.justice.ie.

Department of Justice, Equality and Law Reform (1999). Integration: A two way process. Report to the Minister for Justice, Equality and Law Reform by the Interdepartmental Working Group on the Integration of Refugees in Ireland, Dublin: Department of Justice, Equality and Law Reform.

Dine, M.K. (2013). Naturalisations Procedures for Immigrants: Slovenia, EUDO Citizenship Observatory, Florence: European University Institute Research Repository, available https://cadmus.eui.eu/bitstream/handle/1814/29797/NPR_2013_33Slovenia. pdf?sequence $=1 \&$ isAllowed $=y$.

Doyle, N., G. Hughes and H. Wadensjo (2006). Freedom of Movement for Workers from Central and Eastern Europe: Experiences in Ireland and Sweden. Stockholm: Swedish Institute for European Policy Studies.

Dronkers, J. and M. Vink (2012). 'Explaining access to citizenship in Europe: How citizenship policies affect naturalization rates', European Union Politics, 13(3) 390-412, https://doi.org/10.1177\%2F1465116512440510. 
EMN Belgium (2018). Labour market integration of third-country nationals in Belgium, available at https://ec.europa.eu/homeaffairs/sites/homeaffairs/files/02a_belgium_labour_market_integration_ final_en.pdf.

EMN Belgium (forthcoming). Pathways to citizenship for third-country nationals in the EU, Common Template for EMN Study 2019, Brussels: European Migration Network.

EMN Bulgaria (2019). Pathways to citizenship for third-country nationals in the EU Member States: Common template for EMN study 2019, Brussels: European Migration Network, available at https://ec.europa.eu/homeaffairs/sites/homeaffairs/files/03_bulgaria_citizenship_study_en.pdf.

EMN Czech Republic (2020). Pathways to citizenship for third-country nationals in EU Member States: Czech Republic, Prague/Brussels: Ministry of the Interior of the Czech Republic/European Migration Network, available at https://ec.europa.eu/home-

affairs/sites/homeaffairs/files/czech_republic_citizenship_study_2019_e n.pdf.

EMN Estonia (2019). Pathways to citizenship for third-country nationals in the EU Member States: Estonian National Report, Brussels: European Migration Network, available at https://ec.europa.eu/homeaffairs/sites/homeaffairs/files/08_estonia_citizenship_study_en.pdf.

EMN Finland (2018). Annual Report on Migration and Asylum: Finland 2017. European Migration Network: Brussels.

EMN Finland (2020). Pathways to citizenship for third-country nationals in the EU Member States Common template for EMN study 2019: Study template Finland. European Migration Network: Brussels, available at https://ec.europa.eu/home-

affairs/sites/homeaffairs/files/09_finland_pathwayds_to_citizenship_201

9_en.pdf.

EMN France (2019). Parcours des ressortissants de pays tiers vers la nationalité (Pathways to citizenship for third-country nationals in France), Paris: Ministry of the Interior, available at www.immigration.interieur.gouv.fr/Europe-et-International/Le-reseaueuropeen-des-migrations-REM3/Le-reseau-europeen-des-migrationsREM2/Etudes.

EMN Germany (2018). Migration, Integration, Asylum: Political Developments in Germany 2017, Annual Policy Report by the German National Contact Point for the European Migration Network, Nuremberg: Federal Office for Migration and Refugees.

EMN Greece (2019). Pathways to citizenship for third-country nationals in the EU Member States. National report: Greece, Brussels: European Migration Network, available at https://ec.europa.eu/homeaffairs/sites/homeaffairs/files/12_greece_pathways_to_citizenship_en.p df.

EMN Hungary (2019). Pathways to citizenship for third-country nationals in the EU Member States: Hungary, Brussels: European Migration Network, available 
https://ec.europa.eu/home-

affairs/sites/homeaffairs/files/13_hungary_citizenship_study_en.pdf.

EMN Luxembourg (2019). Pathways to citizenship for third-country nationals in Luxembourg, Esch-Belval/Brussels: University of Luxembourg/European Migration Network, available at https://ec.europa.eu/homeaffairs/whatwedo/networks/european_migra tion_network/reports_en.

EMN Netherlands (forthcoming). Pathways to citizenship for third-country nationals in the EU, Common Template for EMN Study 2019, Brussels: European Migration Network.

Ersbøll, E. (2015). Report on Citizenship Law: Denmark, EUDO Citizenship Observatory, Florence: European University Institute, available: https://cadmus.eui.eu/bitstream/handle/1814/36504/EUDO_CIT_CR_20 15_14_Denmark.pdf?sequence=1\&isAllowed=y.

Etzioni, A. (2007). 'Citizenship Tests: A Comparative, Communitarian Perspective', The Political Quarterly, Vol.78, No.3, pp. 353-363.

European Commission (2014). Communication from the Commission to the European Parliament and the Council on guidance for application of Directive 2003/86/EC on the right to family reunification, COM(2014) 210 final.

European Commission (2019). Report from the Commission to the European Parliament and the Council on the implementation of Directive 2003/86/EC on the right to family reunification, $\operatorname{COM(2019)} 162$ final.

European Migration Network (2011). Ad-hoc query on citizenship tests, Brussels: European Migration Network, available at https://ec.europa.eu/homeaffairs/sites/homeaffairs/files/what-we-

do/networks/european_migration_network/reports/docs/ad-hocqueries/integration/297_emn_adhoc_query_citizenship_tests_24feb2011_wider_dissemination_en.pdf.

European Migration Network (2012). Ad-hoc query on citizenship tests, Brussels: European Migration Network, available at https://ec.europa.eu/homeaffairs/sites/homeaffairs/files/what-wedo/networks/european_migration_network/reports/docs/ad-hocqueries/integration/399_emn_adhoc_query_citizenship_tests_27april2012wider_dissemination_en.pdf.

European Migration Network (2020). Pathways to citizenship for third-country nationals in the EU: EMN Synthesis report for the EMN Study 2019, Brussels: European Migration Network.

Fahey, É., H. Russell, F. McGinnity and R. Grotti (2019). Diverse Neighbourhoods: An Analysis of the Residential Distribution of Immigrants in Ireland. Dublin: ESRI/Department of Justice and Equality.

Farahat, A. and K. Hailbronner (2020). Report on Citizenship Law: Germany, GLOBALCIT, Florence: European University Institute, available at https://cadmus.eui.eu/bitstream/handle/1814/66430/RSCAS_GLOBALCIT _CR_2020_5.pdf?sequence=1\&isAllowed=y. 
Feldman, A., M. Gilmartin, L. Steven and M. Bettina (2008). Getting On: From Migration to Integration - Chinese, Indian, Lithuanian and Nigerian Migrants' Experiences in Ireland, Dublin: Immigrant Council of Ireland.

Foblets, M., Z. Yanasmayan and P. Wautelet (2013). Country Report: Belgium, EUDO Citizenship Observatory, Florence: European University Institute.

Fonseca, M.L., M. Caldeira and A. Esteves (2002). 'New forms of migration into the European South: Challenges for citizenship and governance - the Portuguese Case', International Journal of Population Geography, Vol. 8 No.2, pp.135-152, https://doi.org/10.1002/ijpg.248.

Fozdar, F. and B. Spittles (2009). 'The Australian Citizenship Test: Process and Rhetoric', in Australian Journal of Politics \& History, Vol. 55, No.2, pp. 496512. https://doi.org/10.1111/j.1467-8497.2009.01529.x.

FRA (2017). Together in the EU Promoting the participation of migrants and their descendants, European Union Agency for Fundamental Rights, Luxembourg: Publications Office of the European Union.

Geets, J., S. van den Eede, J. Wets, M. Lamberts and C. Timmerman (2007). Hoe wordt het inburgeringsbeleid geapprecieerd? Evaluatie vanuit het perspectief van de nieuwkomers (What value does the integration policy have? Evaluation from the perspective of newcomers), Leuven: HIVA.

Gelderloos, W. and J. van Koert (2010). Inburgeren en participeren: Verslag van vier kwalitatieve casestudies naar de effecten van inburgering op participatie (Integration and participation: Report from four qualitative studies on the effects of integration on participation), The Hague: B\&A Consulting bv, available www.parlementairemonitor.nl/9353000/1/j9vvij5epmj1ey0/viiuoy070hy q.

Gidley, B., A. Canganio, Z. Khor and D. Kiwan (2012). Citizenship and Integration in the UK, COMPAS, Oxford: University of Oxford.

Gil, A. and N. Piçarra (2020). Report on Citizenship Law: Portugal, Florence: Global Citizenship Observatory, available at https://cadmus.eui.eu/bitstream/handle/1814/66204/RSCAS_GLOBALCIT _CR_2020_1.pdf?sequence=1\&isAllowed=y.

Goodman, S.W. (2010). 'Integration Requirements for Integration's Sake? Identifying, Categorising and Comparing Civic Integration Policies', Journal of Ethnic and Migration Studies, Vol. 36, No. 5, pp. 753-772.

Goodman, S.W. (2014). Immigration and Membership Politics in Western Europe. Cambridge University Press.

Goodman, S.W. and M. Wright (2015). 'Does Mandatory Integration Matter? Effects of Civic Requirements on Immigrant Socio-economic and Political Outcomes', Journal of Ethnic and Migration Studies, Vol. 41, No. 12, pp. 1885-1908.

Goodman, S.W. and M. Howard (2013). 'Evaluating and Explaining the Restrictive Backlash in Citizenship Policy in Europe', in A. Sarat (ed.), Special Issue: Who Belongs? Immigration, Citizenship, and the Constitution of Legality 
(Studies in Law, Politics, and Society, Vol. 60, pp. 111-139). Bingley: Emerald Group Publishing Limited. https://doi.org/10.1108/S10594337(2013)0000060009.

Gossiaux, A., E. Mescoli and M. Rivière (2019). Évaluation du parcours d'intégration et du dispositive ISP dédiés aux primo-arrivants en Wallonie (Evaluation of the integration course and socio-professional integration for first-time arrivals in the Walloon Region), Research Report No. 33, Namur: Institut wallon de l'évaluation, de la prospective et de la statistique, available at www.iweps.be/publication/evaluation-parcours-dintegration-dispositifisp-dedies-aux-primo-arrivants-wallonie/.

Gozdecka, D.A. (2013). Naturalisation Procedures for Immigrants: Finland, EUDO Citizenship Observatory. Robert Schuman Centre for Advanced Studies, Florence: European University Institute.

Groarke, S. and C. Durst (2019). Attracting and retaining international higher education students, European Migration Network, ESRI Research Series No. 88, Dublin: Economic and Social Research Institute.

Gusciute, E., E. Quinn, and A. Barrett (2015). Determining Labour and Skills Shortages and the Need for Labour Migration in Ireland. ESRI Research Series Number 49, Dublin: European Migration Network and Economic and Social Research Institute.

Hajjat, A. (2013). Naturalisation Procedures for Immigrants: France, EUDO Citizenship Observatory, Florence: European University Institute. available at https://cadmus.eui.eu/bitstream/handle/1814/29782/NPR_2013_03CITIMP-France.pdf?sequence=1\&isAllowed=y.

Healy, C. (2007). On Speaking Terms: Introductory and Language Programmes for Migrants in Ireland. Dublin: Immigrant Council of Ireland.

Healy, C. (2013). Naturalisation Procedures for Immigrants: Portugal, EUDO Citizenship Observatory, Florence European University Institute.

Home Office (2002). Secure Borders, Safe Haven: Integration with Diversity in Modern Britain, London: Home Office, available at https://assets.publishing.service.gov.uk/government/uploads/system/upl oads/attachment_data/file/250926/cm5387.pdf.

Home Office (2003). The New and the Old: The report of the 'Life in the United Kingdom' Advisory Group, London: Home Office.

Home Office (2009). Earning the right to stay: a new points test for citizenship, London: UK Border Agency, available at www.london.gov.uk/moderngov/Data/Business\%20Management\%20and \%20Administration\%20Committee/20091022/Agenda/16a\%20Appendix \%20A\%20PDF.pdf.

Home Office (2020). Immigration Statistics year ending December 2019. London: Home Office, available at https://assets.publishing.service.gov.uk/government/uploads/system/upl oads/attachment_data/file/868079/citizenship-summary-dec-2019tables.xIsx. 
Honohan, I. (2017). 'Liberal and Republican Conceptions of Citizenship' in Shachar, A., R. Bauböck, I. Bloemraad and M. Vink (eds.) (2017). The Oxford Handbook of Citizenship, Oxford: Oxford University Press, https://doi.org/10.1093/oxfordhb/9780198805854.013.4.

Horner, K. (2017). 'Language regimes and acts of citizenship in multilingual Luxembourg', in Milani, T.M. (ed), Language and Citizenship: Broadening the Agenda, Amsterdam: John Benjamins Publishing Company.

Horwath Consulting Ireland, Rambøll Management and Matrix Knowledge Group (2008). Final Report to Office of the Minister for Integration and the Department of Education \& Science: Development of a National English Language Policy and Framework for Legally-Resident Adult Immigrants, available at www.education.ie/en/Publications/PolicyReports/horwath_final_report.pdf.

Huddleston, T., J. Niessen and J. Dag Tjaden (2013). Using EU Indicators of Immigrant Integration. Final Report for Directorate-General for Home Affairs, Brussels: European Commission.

Huddleston, T., O. Bilgili, A-L. Joki and Z. Vankova (2015). Migrant Integration Policy Index 2015, Barcelona/Brussels: CIDOB and MPG.

Instituto Cervantes (2020). 'Procedimiento de administración de la prueba CCSE en condiciones especiales (Procedure for administering the CCSE exam under special conditions)', available at https://examenes.cervantes.es/sites/default/files/CCSE_Procedimiento_ necesidades_especiales_2020_0.pdf.

Irish Vocational Education Association (2001). IVEA Policy on Educational Provision for Asylum Seekers, Refugees and other Non-nationals: An Irish Vocational Education Association Working Group Report 2001, Dublin: IVEA.

Jensen, K., C. Fernandez and G. Brochmann (2017). 'Nationhood and Scandinavian naturalization politics: varieties of the civic turn', Citizenship Studies, 21(5) 606-624, http://dx.doi.org/10.1080/13621025.2017.1330399.

Joppke, C. (2007). 'Beyond national models: Civic integration policies for immigrants in Western Europe', West European Politics, 30(1), 1-22, available at https://doi.org/10.1080/01402380601019613.

Joppke, C. (2010). Citizenship and immigration, Cambridge: Polity Press.

Joppke, C. (2017). 'Civic integration in Western Europe: three debates', West European Politics, 40 (6) 1153-1176, available at: https://doi.org/10.1080/01402382.2017.1303252.

Kaldur, K., R. Vetik, L. Kirss, K. Kivistik, K. Seppel, K. Kallas, M. Masso and K. Anniste (2017). Eesti ühiskonna integratsiooni monitooring 2017 (Estonian society integration monitoring 2017), Tartu: Balti Uuringute Instituut, available at www.kul.ee/et/EIM2017.

Kett, M. (2018). English language provision and language assessment for lowskilled and unemployed migrants: Recommendations for good practice at NFQ levels 1-3 in ETBs, Dublin: Education and Training Boards Ireland \& 
SOLAS, available at www.solas.ie/f/70398/x/7a61ee6ee9/englishlanguage-provision-and-language-assessment.pdf.

Koopmans, R., P. Statham, M. Giugni and F. Passy (2005). Contested Citizenship. Immigration and Cultural Diversity in Europe. Minneapolis and London: Minnesota University Press.

Kostakopoulou, D. (2001). Citizenship, Identity, and Immigration in the European Union: Between Past and Future. Manchester: Manchester University Press.

Krūma, K. (2013). Naturalisation Procedures for Immigrants: Latvia, EUDO Citizenship Observatory, Florence: European University Institute, available at https://cadmus.eui.eu/bitstream/handle/1814/29788/NPR_2013_20Latvia. pdf?sequence=1\&isAllowed=y.

Kūris, E. (2010). Country Report: Lithuania, EUDO Citizenship Observatory, Florence: European University Institute, available at https://cadmus.eui.eu/bitstream/handle/1814/19622/Lithuania.pdf?seq uence $=1 \&$ isAllowed $=y$.

Kusá, D. (2013). Country Report: Slovakia, EUDO Citizenship Observatory, Florence: European University Institute.

Lafleur, J.M. and A. Marfouk (2019). A Common Home: Migration and Development in Belgium, Brussels: Caritas International Belgium, available at www.caritas.eu/wordpress/wpcontent/uploads/2019/06/CommonHomeBelgiumEN.pdf.

Lister, M. (2008). 'Theories of Citizenship', in M. Lister and E. Pia (eds.), Citizenship in Contemporary Europe. Edinburgh University Press, available at https://edinburgh.universitypressscholarship.com/view/10.3366/edinbur gh/9780748633418.001.0001/upso-9780748633418-chapter-2.

Little, D. (2008). 'The Common European Framework of Reference for Languages and the development of policies for the integration of adult migrants', Strasbourg: Council of Europe, available at https://rm.coe.int/16802fc0b1.

Little, D. (2012). 'The linguistic integration of adult migrants and the Common European Framework of Reference for Languages', Strasbourg: Council of Europe, available at https://rm.coe.int/16802fc1ca.

Mac Síthigh, D. (2018). 'Official status of languages in the United Kingdom and Ireland', in Common Law World Review, Vol. 47, No. 1, pp. 77-102, available at https://doi.org/10.1177/1473779518773642.

Marshall, T.H. (1950). Citizenship and Social Class, and Other Essays. Cambridge University Press.

McGinnity, F., É. Fahey, E. Quinn, S. Arnold, B. Maître and P. O'Connell (2018). Monitoring report on Integration 2018, Dublin: Economic and Social Research Institute and Department of Justice and Equality.

McGinnity, F., E. Quinn, G. Kingston and P. O'Connell (2012). Annual Monitoring Report on Integration 2011, Dublin: Economic and Social Research Institute and The Integration Centre. 
McGinnity, F., E. Quinn, G. Kingston and P. O'Connell (2013). Annual Monitoring Report on Integration 2012, Dublin: Economic and Social Research Institute and The Integration Centre.

McGinnity, F., I. Privalko, É. Fahey, S. Enright and D. O'Brien (2020). Origin and Integration: a study of migrants in the 2016 Irish Census. Dublin: Economic and Social Research Institute and Department of Justice and Equality.

Michalowski, I. (2011). 'Required to assimilate? The content of citizenship tests in five countries', Citizenship Studies, Vol. 15, No. 6-7, pp. 749-768.

Migration Policy Group and France Terre d'Asile (2018). Access to citizenship and its impact on immigrant integration: Handbook for France, , EUDO Citizenship Observatory, Florence: European University Institute, available at https://cadmus.eui.eu/bitstream/handle/1814/29764/ACIT_Handbook_F rance_ENGLISH.pdf?sequence $=1 \&$ isAllowed $=y$.

Migration Policy Group and Iniziative e studi sulla multietnicità (2013). Access to citizenship and its impact on immigrant integration: Handbook for Italy, EUDO Citizenship Observatory, Florence: European University Institute, available https://cadmus.eui.eu/bitstream/handle/1814/32271/ACIT_Handbook_It aly_ENGLISH_.pdf?sequence=2\&isAllowed=y.

Myria (2015). La migration en chiffres et en droits 2015 (Migration in figures and rights 2015), Brussels: Myria, available at www.myria.be/files/Migrationrapport_2015-LR.pdf.

Myria (2017). La migration en chiffres et en droits 2017 (Migration in figures and rights 2017), Brussels: Myria, available at www.myria.be/files/MIGRA2017_FR_AS.pdf.

Myria (2018). La migration en chiffres et en droits 2018 (Migration in figures and rights 2018), Brussels: Myria, available at www.myria.be/files/MIGRA2018_FR_AS_1.pdf.

Noppe, J., M. Vanweddingen, G. Doyen, K. Stuyck, Y. Feys and P. Buysschaert (2018). Vlaamse Migratie- en Integratiemonitor 2018 (Flemish Migration and Integration Monitor 2018), Brussels: Agentschap Binnenlands Bestuur.

Objectif (2015). 'Contribution à l'examen périodique universel du conseil des Droits de I'homme des nations unies Belgique - 2015 (Contribution to the Universal Periodic Review of Belgium by the UN Human Rights Council 2015)', Brussels: Objectif, Mouvement pour l'égalité des droits, available at

https://uprdoc.ohchr.org/uprweb/downloadfile.aspx?filename=2251\&fil $\mathrm{e}=$ FrenchTranslation.

OECD (1997). Trends in International Migration 1997: Continuous Reporting System on Migration, Paris: Organisation for Economic Co-operation and Development.

OECD (2018a). Settling In 2018: Indicators of Immigrant Integration, Paris/Brussels: OECD Publishing and European Union. 
OECD (2018b). International Migration Outlook 2018, Paris: OECD Publishing, https://doi.org/10.1787/migr_outlook-2018-en.

OECD (2018c). 'Migration in Finland and the context of integration policy', in Working Together: Skills and Labour Market Integration of Immigrants and their Children in Finland, OECD Publishing, Paris. https://doi.org/10.1787/9789264305250-5-en.

OECD (2019). International Migration Outlook 2019, Paris: OECD Publishing, https://doi.org/10.1787/c3e35eec-en.

Office of the Minister for Integration (2008). Migration Nation: Statement on integration strategy and diversity management, Dublin: Department of Justice, Equality and Law Reform.

Oliveira, C.R. and N. Gomes (2019). Indicadores de Integração de Imigrantes: Relatório Estatístico Anual 2019 (Indicators of migrant integration: Annual statistical report 2019), Lisbon: Observatório das Migrações, available at www.om.acm.gov.pt/documents/58428/383402/Indicadores+de+Integra \%C3\%A7\%C3\%A3o+de+Imigrantes.+Relat\%C3\%B3rio+Estat\%C3\%ADstico +Anual+2019/98bf34e6-f53f-41b9-add6-cdb4fc343b34.

Oliveira, C.R., N. Gomes and T. Santos (2017). Aquisição da Nacionalidade Portuguesa: 10 anos da Lei em Números (Acquisition of Portuguese nationality: 10 years of the law in numbers), Lisboa: Observatório das Migrações, available at www.om.acm.gov.pt/documents/58428/440932/Caderno+Estat\%C3\%AD stico+1+Nacionalidade+FINAL_b.pdf/787fbb3d-d8ea-4daa-922d5 cbefec49ff4.

Orgad, L. (2017). 'Naturalization' in Shachar, A., R. Bauböck, I. Bloemraad and M. Vink (eds.). The Oxford Handbook of Citizenship, Oxford: Oxford University Press, https://doi.org/10.1093/oxfordhb/9780198805854.013.15.

Papademetriou, D.G. and M. Benton (2016). From Fragmentation to Integration: Towards a 'Whole-of-Society' Approach to Receiving and Settling Newcomers in Europe, Brussels: Bertelsmann Stiftung.

Paparusso, A. (2019). 'Immigrant citizenship status in Europe: The role of individual characteristics and national policies', Genus, Vol. 75, No. 13, https://doi.org/10.1186/s41118-019-0059-9.

Paquet, M. (2012). 'Beyond Appearances: Citizenship Tests in Canada and the UK', Journal of International Migration and Integration, Vol.13, No.2, pp. 243260.

Parliamentary Assembly of the Council of Europe (2014). Integration tests: helping or hindering integration?, Strasbourg: Council of Europe, available at www.assembly.coe.int/nw/xml/XRef/Xref-DocDetails-

EN.asp?FileID $=20481 \&$ lang=EN.

Paskalev, V. (2013). Naturalisation Procedures for Immigrants: Bulgaria, EUDO Citizenship Observatory, Florence: European University Institute Research Repository, available at https://cadmus.eui.eu/bitstream/handle/1814/29775/NPR_2013_34Bulg aria. pdf? sequence $=1 \&$ isAllowed $=y$. 
Pauwels, F. and M. Lamberts (2010). Deel 3: De impact van inburgering (Part 3: The impact of integration), Leuven: HIVA.

Pochon-Berger, E. and P. Lenz (2014). Language requirements and language testing for immigration and integration purposes: A synthesis of academic literature, Report of the Research Centre on Multilingualism, Fribourg: Institute of Multilingualism.

Pogonyi, S. (2013). Naturalisation Procedures for Immigrants: Hungary, EUDO Citizenship Observatory, Florence: European University Institute, available at https://cadmus.eui.eu/bitstream/handle/1814/29785/NPR_2013_12Hun gary.pdf?sequence $=1 \&$ is Allowed $=\mathrm{y}$.

Poleshchuk, V. (2013). Naturalisation Procedures for Immigrants: Estonia, EUDO Citizenship Observatory, Florence: European University Institute, available at https://cadmus.eui.eu/bitstream/handle/1814/29780/NPR_2013_08Estonia.pdf? sequence=1\&isAllowed=y.

Pulinx, R. and P. Van Avermaet (2015). 'Integration in Flanders (Belgium) Citizenship as achievement: How intertwined are 'citizenship' and 'integration' in Flemish language policies?', in Journal of Language and Politics, Vol. 14, No. 3, pp. 335-358.

Pulinx, R., P. Van Avermaet and C. Extramiana (2014). Linguistic integration of adult migrants: Policy and practice. Final Report on the 3rd Council of Europe Survey. Strasbourg, France: Council of Europe, available at https://rm.coe.int/CoERMPublicCommonSearchServices/DisplayDCTMCo ntent?documentld=09000016802fc1ce.

Puzzo, C. (2016). 'UK Citizenship in the Early $21^{\text {st }}$ Century: Earning and Losing the Right to Stay', in Revue Française de Civilisation Britannique, Vol. 21, No. 2, pp. 1-18.

Reichel, D. and B. Perchinig (2014). 'Reflections on the value of citizenship explaining naturalisation practices', in Österreichische Zeitschrift Für Politikwissenschaft, Vol. 44, No. 1, pp. 32-45, https://doi.org/10.15203/ozp.282.vol44iss1.

Ritchie, D. (2001). Oldham Independent Review. One Oldham, one future. Oldham: Oldham Independent Review, available at http://image.guardian.co.uk/sys-

files/Guardian/documents/2001/12/11/Oldhamindependentreview.pdf.

Rocca, L., C. Hamnes Carlsen and B. Deygers (2020). Linguistic integration of adult migrants: Requirements and learning opportunities. Report on the 2018 Council of Europe and ALTE survey on language and knowledge of society policies for migrants, Strasbourg: Council of Europe, available at https://rm.coe.int/linguistic-integration-of-adult-migrants-requirementsand-learning-opp/16809b93cb.

Ruškyte, R. (2013). Naturalisation Procedures for Immigrants: Lithuania, EUDO Citizenship Observatory, Florence: European University Institute.

Sajfert, J. (2013). Naturalisation Procedures for Immigrants: Croatia, EUDO Citizenship Observatory, Florence: European University Institute, available 
at https://cadmus.eui.eu/bitstream/handle/1814/29776/NPR_2013_10-

Croatia.pdf?sequence $=1 \&$ isAllowed $=y$.

Sawyer, C. and H. Wray (2014). Country Report: United Kingdom, EUDO Citizenship Observatory, Florence: European University Institute, available at https://cadmus.eui.eu/bitstream/handle/1814/33839/EUDO-

CIT_2014_01_UK.pdf?sequence=1\&isAllowed=y.

Schneider, J. (2010). 'Memory Test: A History of US Citizenship Education and Examination', in Teachers College Record, Vol. 112, No. 9, pp. 2379-2404.

Schuck, P. (2003). Diversity in America: Keeping Government at a Safe Distance. Cambridge: Harvard University Press.

Schuller, K., S. Lochner and N. Rother (2011). Das Integratiospanel: Ergebnisse einer Langsschnittstudie zur Wirksamkeit und Nachhaltigkeit von Integrationskursen (The integration panel: results of a longitudinal study on the effectiveness and sustainability of integration courses), Nuremberg: Federal Office for Migration and Refugees.

Schuller, K., S. Lochner and N. Rother (2011). Integration Panel Results of a longitudinal study on the effectiveness and sustainability of integration courses (Summary in English). Nuremberg: Federal Office for Migration and Refugees.

Scuto, D. (2013). Naturalisations Procedures for Immigrants: Luxembourg, EUDO Citizenship Observatory, Florence: European University Institute, available at: http://hdl.handle.net/1814/29790.

Senate Legal and Constitutional Affairs Committee (2017). Submission to the Inquiry into the Australian Citizenship Legislation Amendment (Strengthening the Requirements for Australian Citizenship and Other Measures) Bill 2017, Canberra: Australian Government, Department of Immigration and Border Protection.

SOLAS (2014). Further Education and Training Strategy 2014-2019, Dublin: SOLAS.

Stern, J. and G. Valchars (2013). Country Report: Austria, EUDO Citizenship Observatory, Florence: European University Institute, available at https://cadmus.eui.eu/bitstream/handle/1814/60232/RSCAS_EUDO_CIT _2013_28.pdf?sequence=1\&isAllowed=y.

Strazzari, D. (2016). 'Linguistic Integration Test and Federalism: A Comparative Analysis', in European Journal of Migration and Law, Vol. 18, pp. 442-466.

Strik, T. (2013). Integration tests: helping or hindering integration? Strasbourg: Parliamentary Assembly of the Council of Europe, Committee on Migration Refugees and Displaced Persons, available at www.assembly.coe.int/nw/xml/XRef/Xref-DocDetailsEN.asp?FileID=19772\&lang=EN.

Strik, T., A. Böcker, M. Luiten and R. van Oers (2010). The INTEC Project: Synthesis Report. Integration and naturalisation tests: the new way to European Citizenship. A comparative study in nine Member States on the national policies concerning integration and naturalisation tests and their effects on integration, Nijmegen: Radboud University Nijmegen. 
Sturge, G. (2020). Migration Statistics. Briefing Paper. Number CBP06077, 6 March 2020, London: House of Commons Library.

Tavan, G. (2009). 'Testing times: the problem of "history" in the Howard Government's Australian citizenship test', in Neumann, K. and G. Tavan, Does history matter? Making and debating citizenship, immigration and refugee policy in Australia and New Zealand, Canberra: The Australian National University E-Press.

Thalgott, P. (2017). 'Foreword', in Beacco J.-C., H.-J. Krumm, D. Little, P. Thalgott and Council of Europe, The linguistic integration of adult migrants, Berlin/Boston: De Gruyter.

Tóth, J. (2010). Country Report Hungary. The INTEC project: Integration and naturalisation tests: the new way to European citizenship, Netherlands: Radboud University Nijmegen.

Van de Pol, S. and D. Vanheule (2018). Mapping of social orientation: the case of Belgium, Antwerp: University of Antwerp, available at http://raccombatproject.eu/wp-content/uploads/2018/02/Mapping-Social-OrientationBE.pdf.

Van Den Anker, C. (2010). 'Transnationalism and Cosmopolitanism: Towards Global Citizenship?', in Journal of International Political Theory, Vol. 6, No. 1, pp. 73-94, https://doi.org/10.3366/E1755088210000467.

Van Oers, R. (2014). Deserving Citizenship: Citizenship Tests in Germany, the Netherlands and the United Kingdom, Leiden: Martinus Nijhoff.

Van Oers, R., B. de Hart and K. Groenendijk (2013). Country Report: The Netherlands, EUDO Citizenship Observatory, Florence: European University Institute.

Van Ruyskensvelde, S. and M. Ketch (2018). 'The civics test: a political or educational tool for creating the perfect citizen? A historian overview of forms and processes of naturalization in the United States', in Encounters in Theory and History of Education, No. 19, pp. 205-220.

Waddington, L. (2013). Access to and Accessibility of Citizenship and Political Participation of People with Disabilities in Europe: Introduction to Two Related 2013 ANED Reports. Synthesis Report for the Academic Network of European Disability Experts, The Academic Network of European Disability Experts (ANED), available at www.disability-europe.net/theme/politicalparticipation? page $=3$.

Winter, E. (2018). 'Passing the Test? From Immigrant to Citizen in a Multicultural Country', Social Inclusion, 6(3) 229-236, http://dx.doi.org/10.17645/si.v6i3.1523

Wodak, R. and S. Boukala (2015). '(Supra)National Identity and Language: Rethinking National and European Migration Policies and the Linguistic Integration of Migrants', in Annual Review of Applied Linguistics, Vol. 35, pp. 253-273.

Xhardez, C. (2016). 'The integration of new immigrants in Brussels: an institutional and political puzzle', in Brussels Studies, No. 105. 
Whitaker Square,

Sir John Rogerson's

Quay, Dublin 2

Telephone +353 1863

2000 Email admindesri.ie

Web www.esri.ie

Twitter AESRIDublin

ISBN 978-0-7070-0535-5 